Fall 6-30-2015

\title{
2015 Miracle Yearbook
}

Cedarville University

Follow this and additional works at: https://digitalcommons.cedarville.edu/yearbooks

Part of the Higher Education Commons, Organizational Communication Commons, and the Public Relations and Advertising Commons

\section{Recommended Citation}

Cedarville University, "2015 Miracle Yearbook" (2015). Yearbooks. 96.

https://digitalcommons.cedarville.edu/yearbooks/96

This Book is brought to you for free and open access by DigitalCommons@Cedarville, a service of the Centennial Library. It has been accepted for inclusion in Yearbooks by an authorized administrator of DigitalCommons@Cedarville. For more information, please contact digitalcommons@cedarville.edu. 





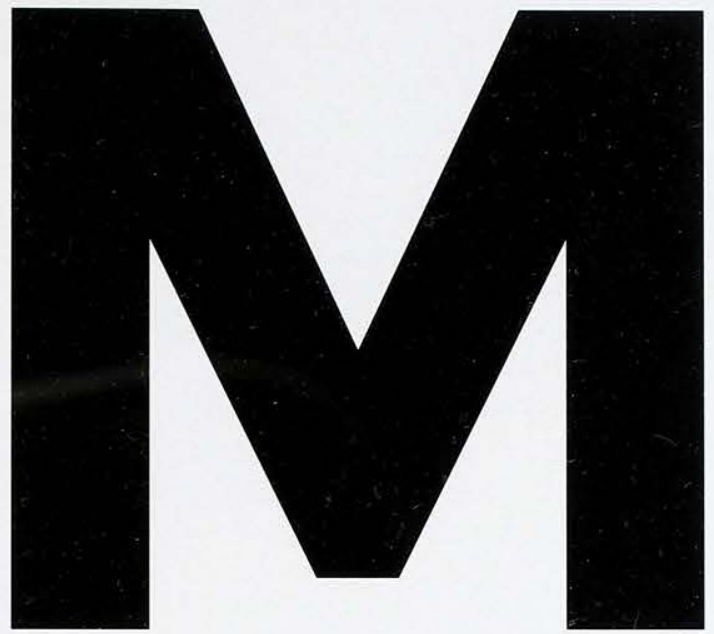

\section{THE MIRACLE YEARBOOK}

Miracle 2014-2015 | Volume 62

Cedarville University | 251 N Main Street, Cedarville, OH 45314

\begin{tabular}{|c|c|c|c|}
\hline OPENING & 2 & WINTER SPORTS & 38 \\
\hline DEDICATION & 3 & SPRING EVENTS & 42 \\
\hline FALL EVENTS & 4 & JS & 46 \\
\hline HOMECOMINC & 10 & ELLIV & 48 \\
\hline FALL SPORTS & 12 & SPRINC SPORTS & 50 \\
\hline CLUB SPORTS & 18 & MIRACLE STAFF & 58 \\
\hline SGA & 20 & ORGANIZATIONS & 60 \\
\hline CLASS COUNCIL & 21 & FACULTY AND STAFF & 66 \\
\hline ACADEMIC TEAMS & 22 & FRESHMEN & 74 \\
\hline MISSIONS TRIPS & 24 & SOPHOMORES & 88 \\
\hline MUSIC & 28 & JUNIORS & 94 \\
\hline THEATRE & 30 & SENIORS & 98 \\
\hline WINTER EVENTS & 32 & COMMENCEMENT & 120 \\
\hline OPEN DORMS & 36 & CLOSINC & 124 \\
\hline
\end{tabular}




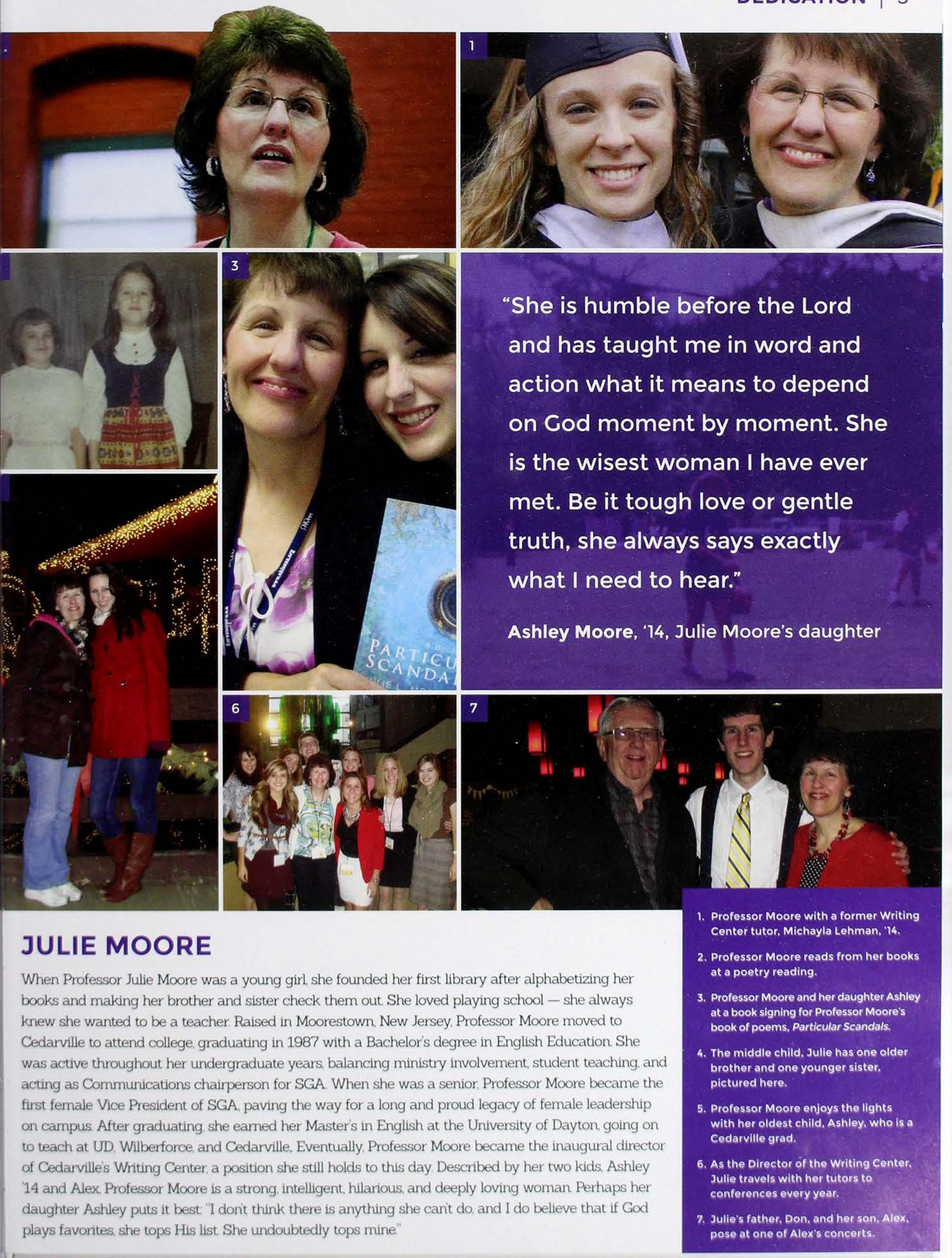





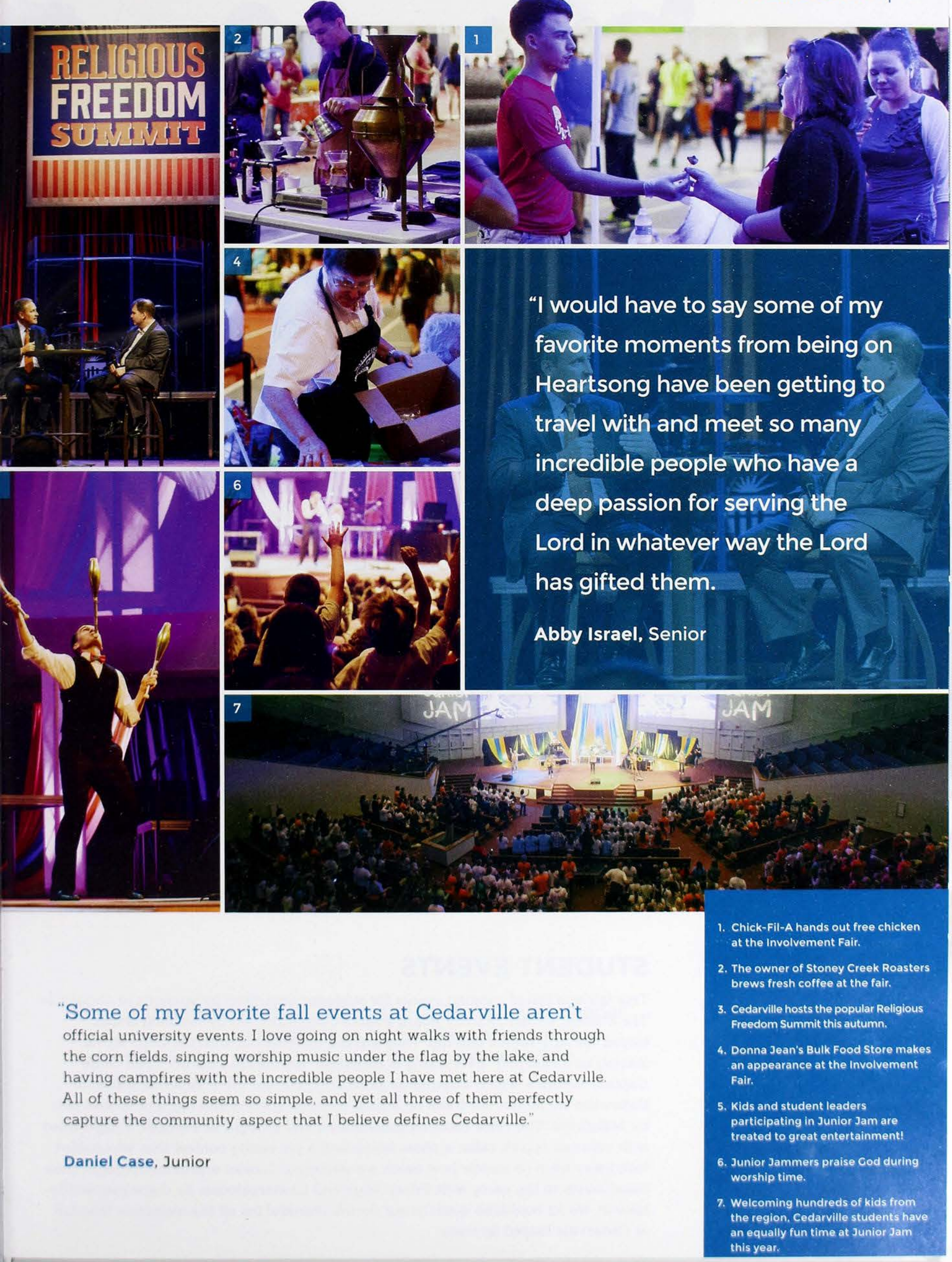




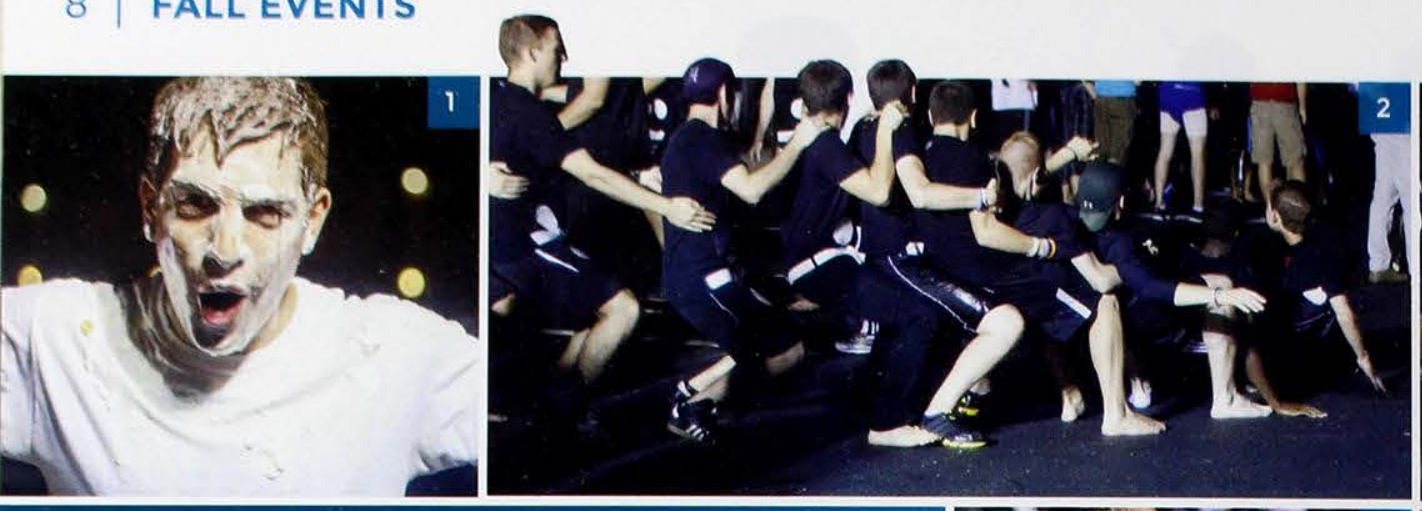

\section{"For one of the Printy Wars activities,} the girls in my unit had to carry me in a blanket several times around the parking lot. I remember laughing so hard and trying to hold myself up to keep them from dropping me. One of the girls gave me a piggyback ride, but she ended up falling."

\section{Abigail Hile, Sophomore}
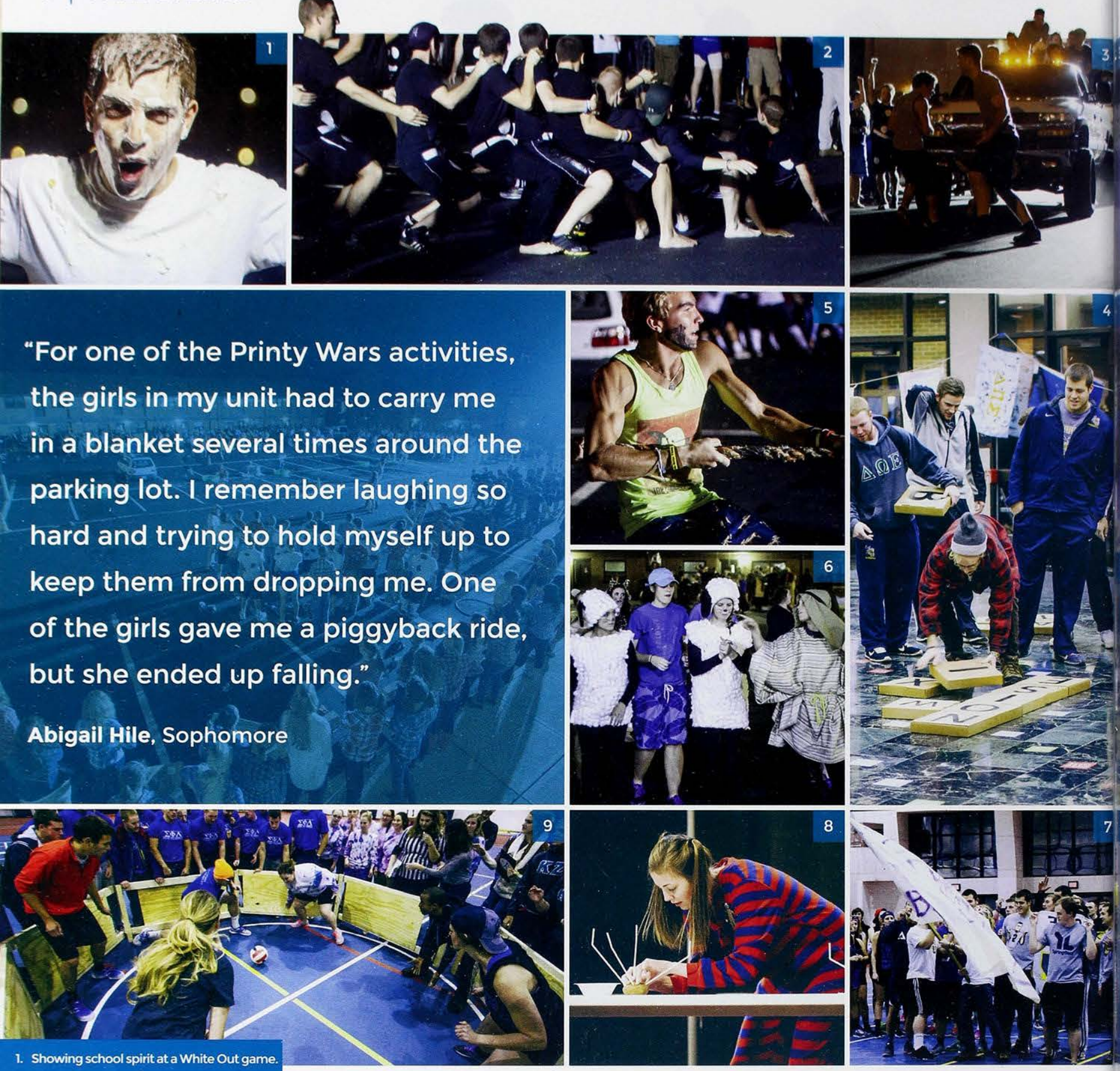

2. Lawlor units 9-12 fall down as a part of their domino-themed costumes.

3. Lawlor men pull trucks and act macho. Welcome to Lawlorpalooza!

4. Giant Scrabble - a favorite at Org Wars this year!

5. Tanner Grindel leads his team - is it to victory?

6. Has there ever been a Printy Wars without a few Noah's Arks?

7. Org Wars team banners abound.

8. You'll never know what crazy stunt you'll have to pull at a Cedarville event.
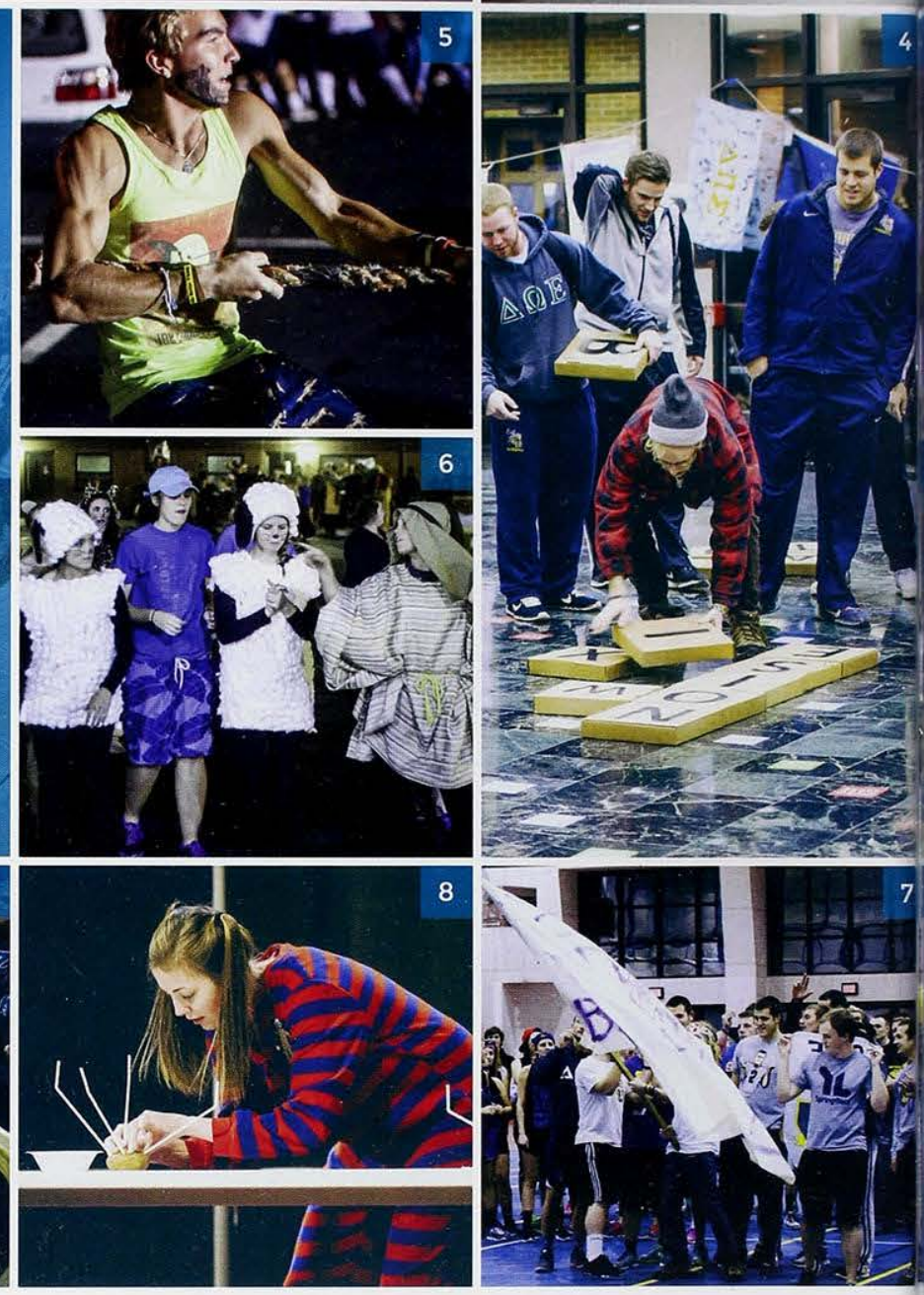

9. GaCa ball gets intense.

\section{STUDENT EVENTS}

This fall was full of exciting events for students, organized by students at Cedarville. The Student Center Activity Board Events Committee, led by Amanda Gabel, slayed the ALT Nights this fall. They started the year out with the Lego Movie. leaving us all singing "Everything is Awesome" for the next month. Then came Captain America, which inspired us all to bring out our inner superhero, and for Halloween we all got our freak on with a costume contest and night of spooks led by Maleficent. The class councils collaborated and brought us Festifall, a night filled with caramel apples, cider, a photo booth and a pie eating contest that we couldn't look away from no matter how much we wanted to. Lawlor and Printy brought their usual antics to the party with Printy Wars and Lawlorpalooza. As the winter winds blew in, we all hunkered down in our dorms, thankful for all the memories that fall at Cedarville helped us make. 

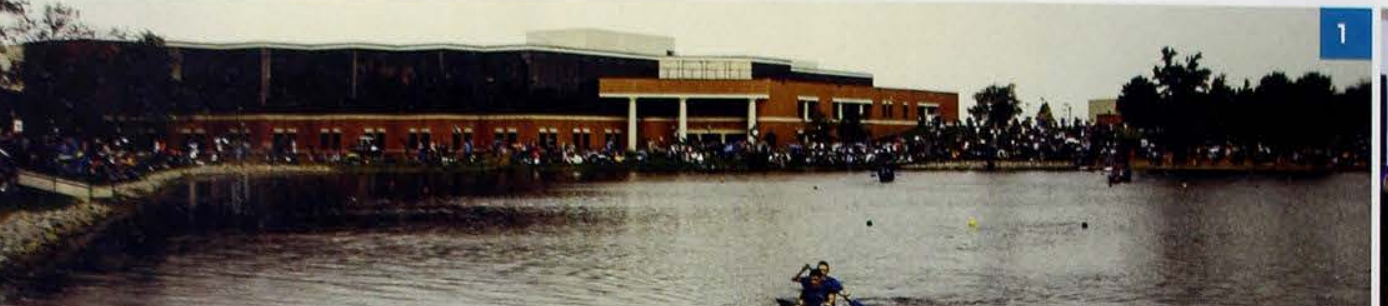

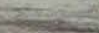
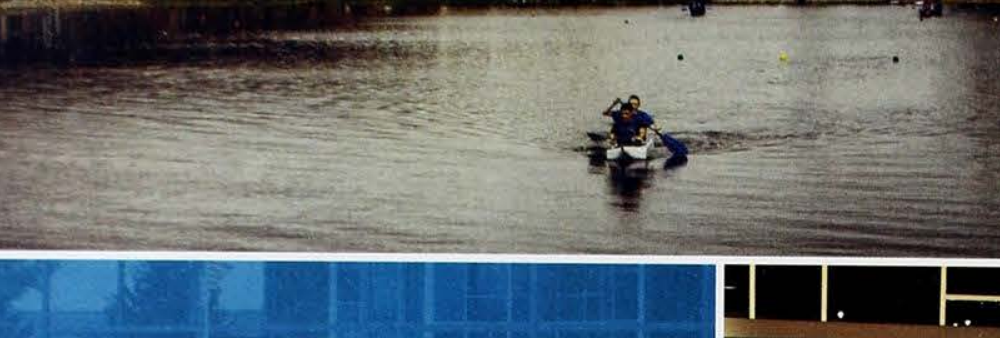

\section{"The week of homecoming also brings} an incredible time in chapels as well. We get to hear all of these incredible Cedarville alumni who have gone on to do such incredible things for the sake of Christ, with everyone from Brian Dye to Pastor Rohm."

\section{Robert Rhodes, Junior}
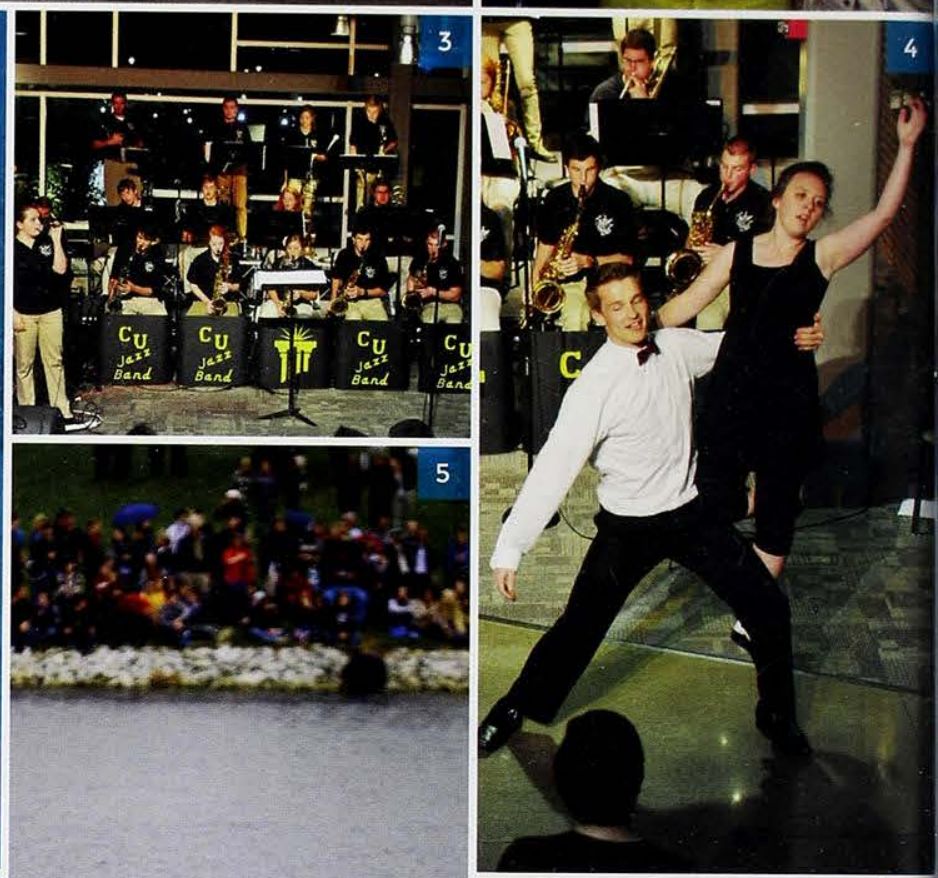

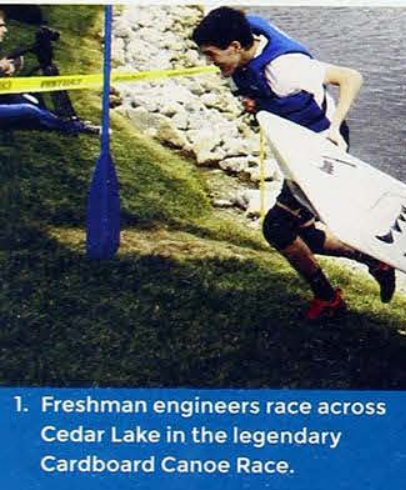

2. Olivia Benitez and Olivia Ochs smile with the Yellow Jacket.

3. The Cedarville Jazz Band and singer Danielle Hutchison entertain guests at Homecoming.

4. Dancers DJ Anderson and Alyssa Griffith join the Jazz Band.

5. Those canoes lucky enough to make it across the lake in one piece have the chance to participate in the Demolition Derby round.

6. Despite the chilly weather this year. everyone comes out to watch the head-to-head races.

\section{WE ARE JACKETS}

Sandra Entner was a new Christian when she came to Cedarville in the 1950s. Jeff Beste came as a student, then as an RD, and eventually as the Director of Alumni, and never left. Murray Murdoch has been teaching at Cedarville for fifty years. What do all these people have in common? They will proclaim, with enthusiasm, that they are Jackets. This year's Homecoming theme reflected the shared heritage of alumni throughout the ages. With all the old favorites - the Homecoming Parade, the Cardboard Canoe Race, CU By the Lake (held in the Field House this year, due to rain) - Homecoming included a few new events as well, like the Acoustic Fire/Interruption Throwback, Barbecue Tailgate, and a Fireworks Show to close out the weekend. Alumni enjoyed reliving Jackets sporting events, seeing the fall play, and catching up with old friends and former professors. Homecoming 2014 attracted over 1,000 people, making it one of the biggest events of the year. Talk about school spirit! 


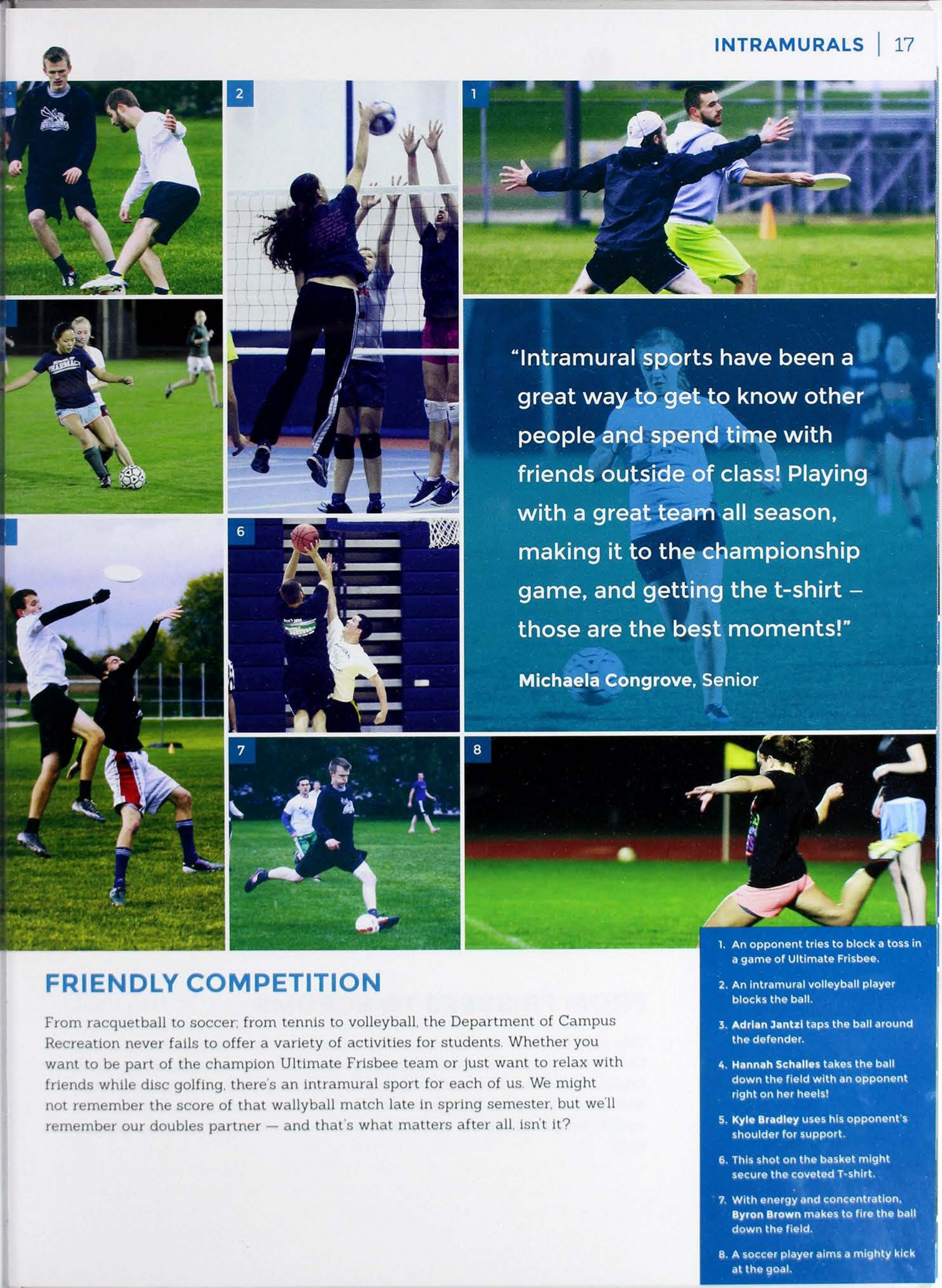




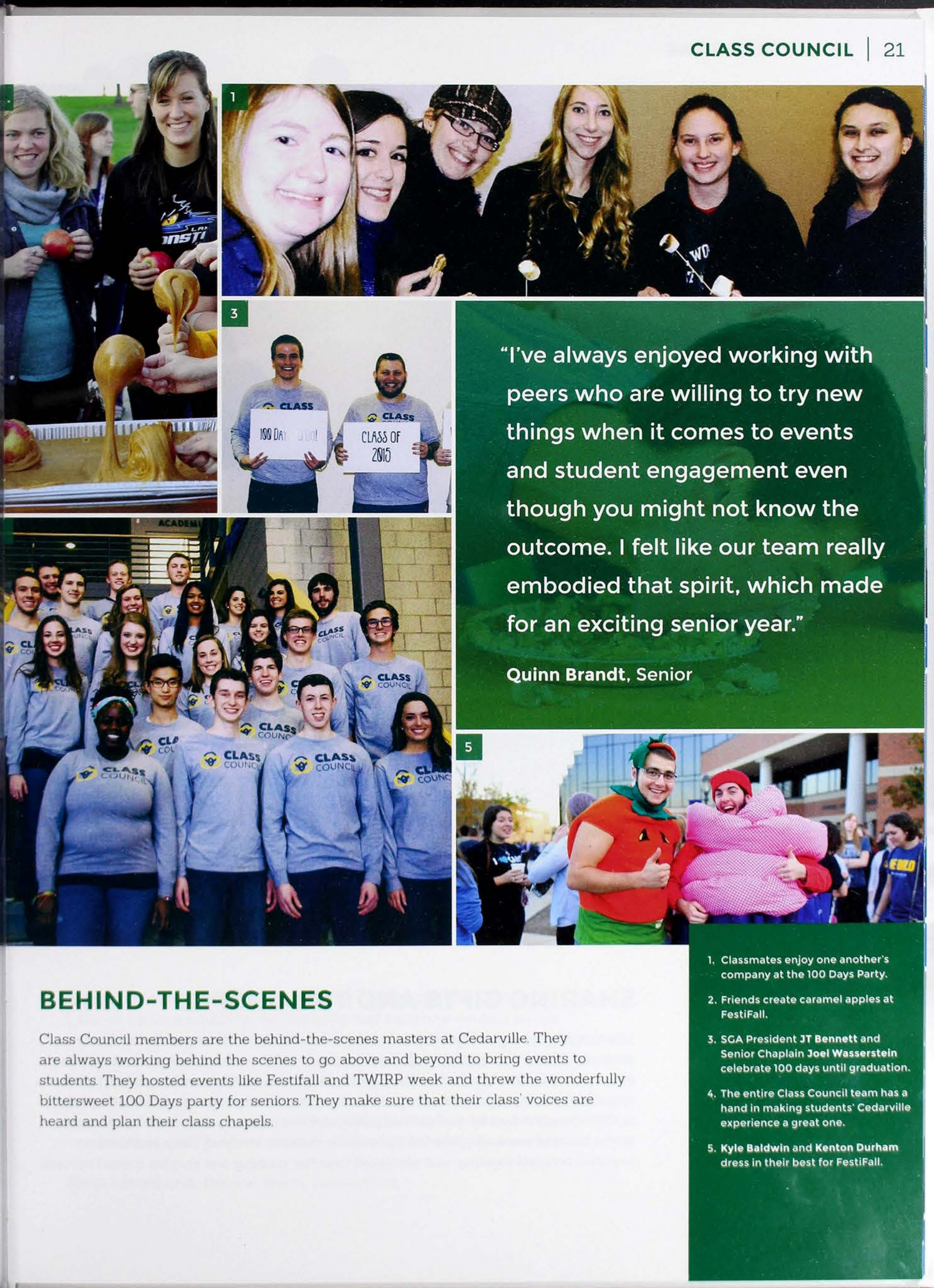



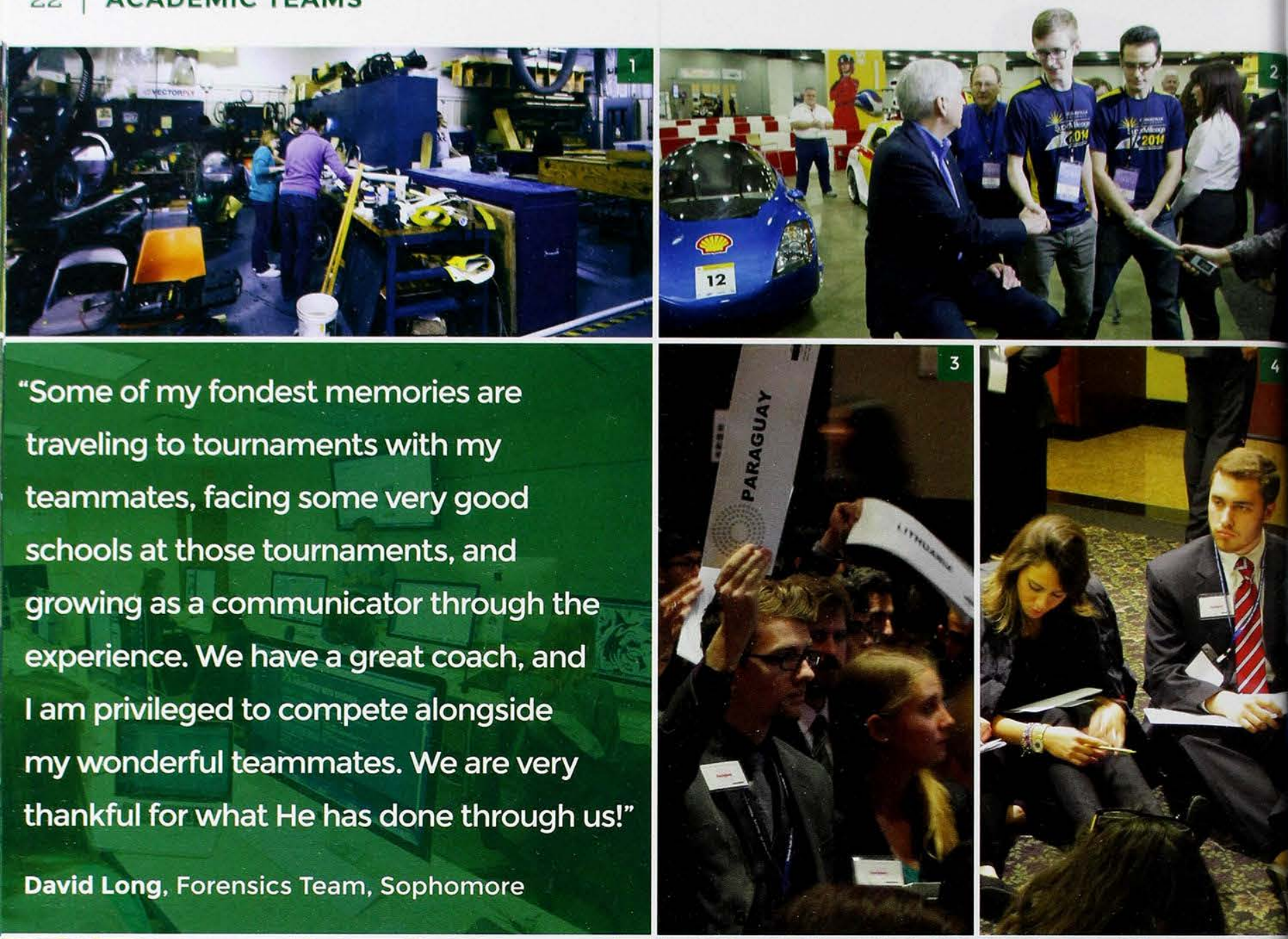

"Some of my fondest memories are traveling to tournaments with my teammates, facing some very good schools at those tournaments, and growing as a communicator through the experience. We have a great coach, and I am privileged to compete alongside my wonderful teammates. We are very thankful for what He has done through us!"

David Long, Forensics Team, Sophomore
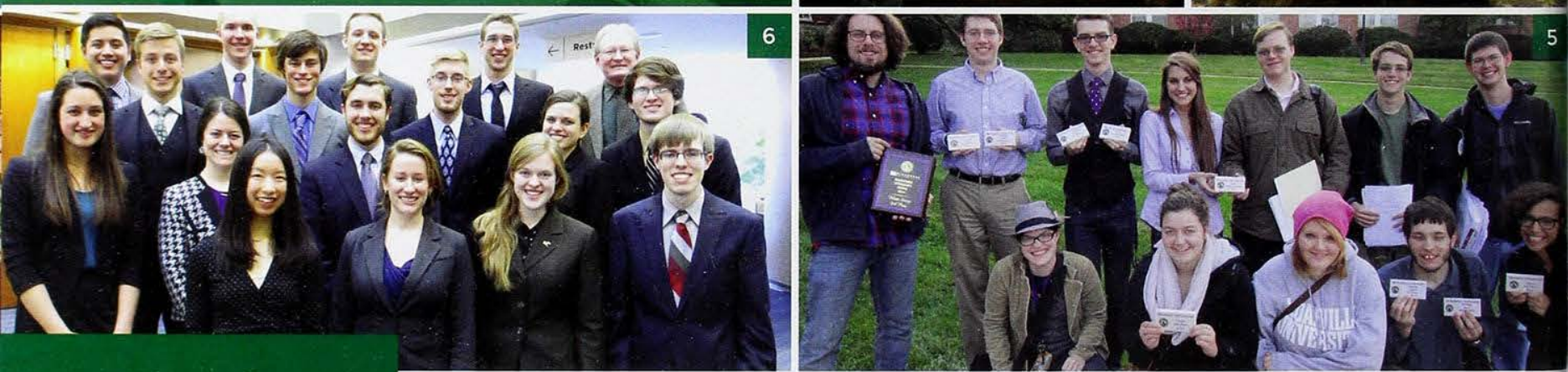

1. The SuperMileage team works hard in the shop.

2. SuperMileage team leader Tyler Dicks shakes Governor Rick Snyder's hand at the Detroit Auto Show.

3. Aaron Alford represents Paraguay at a Model UN tournament.

4. Carson Doyle discusses tactics with other Model UN members.

5. The Debate Team gathers to show off their awards.

6. Dr. Jenista advises Cedarville's Model UN team.

\section{SHARING GIFTS AND THE GOSPEL}

Whether it is through Model UN or Debate Team, SEAM or Forensics, Cedarville students had the opportunity to go into the community - and across the country - to share their gifts and the Gospel. Through academic teams, Cedarville students had the opportunity to travel to various regional and national competitions, often placing high in their divisions. Led by experienced professors and advisors, Cedarville academic teams became something like family to those students involved. They practiced together, traveled together, and competed together, pushing one another toward success. 


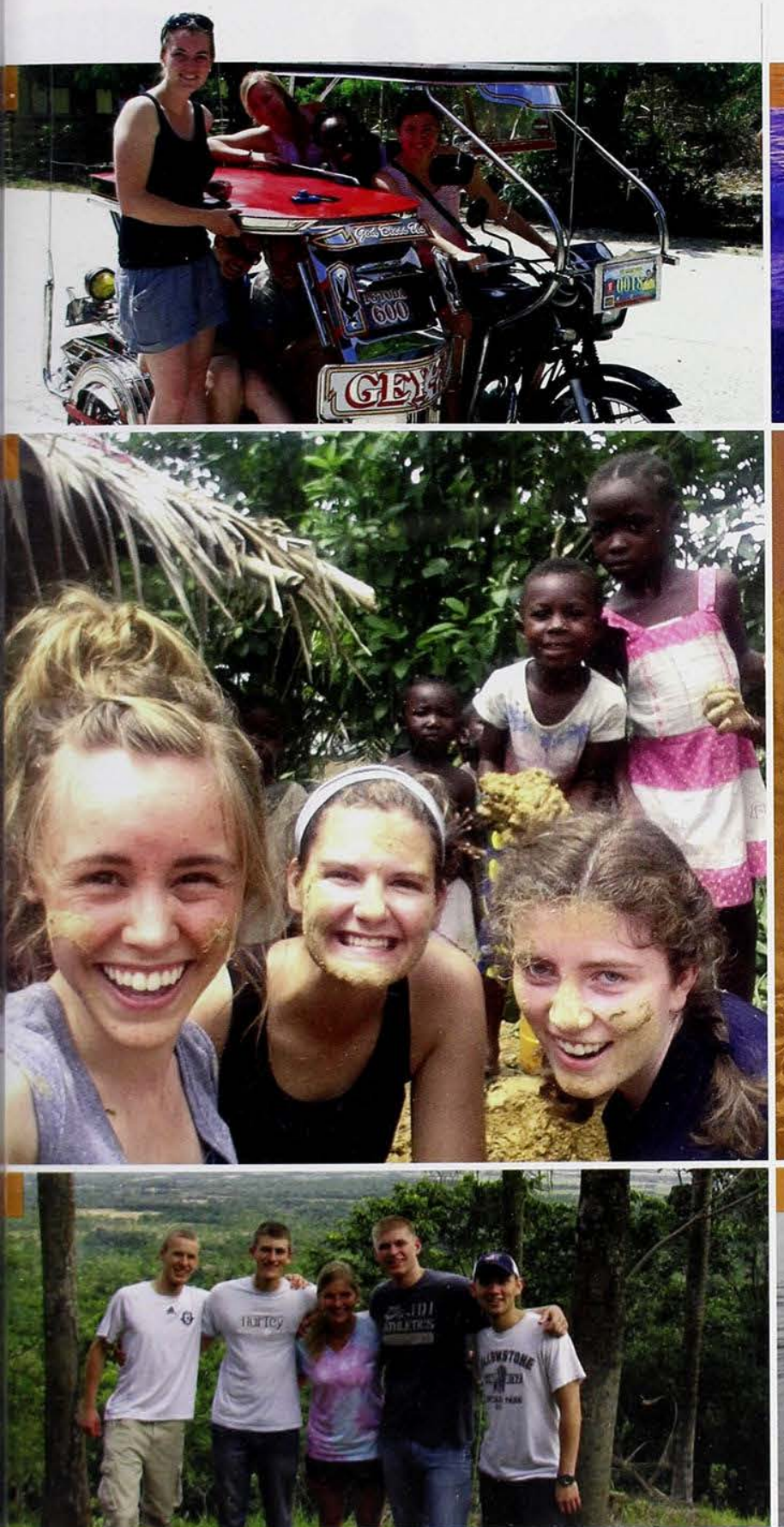

God was definitely moving in the people of Swaziland! His love and joy overflowed in people that we would normally think should be remorseful or bitter. God shattered our expectations of what serving in an area ravaged by HIV would be like. His perfect love casts out all fear:) During the months leading up to our departure our team prayed earnestly that God would teach us and that we would be listening. He absolutely did! Above all else $\mathrm{He}$ taught us humility beyond what we imagined. He didn't need a single one of us there but He chose to use us and for that we are thankful

Kevin Gahman, Senior, Swaziland Team

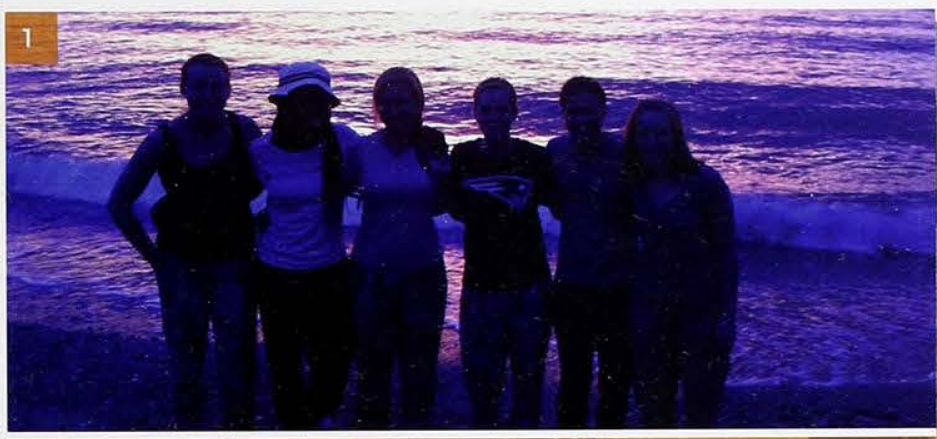

"Cataloging books for the Evangelical Seminary was exponentially rewarding because every book we put into the system was one more book a student could use to further their Christian education an education that follows them to everywhere they go."

\section{Rebecca Brumbaugh, Senior}

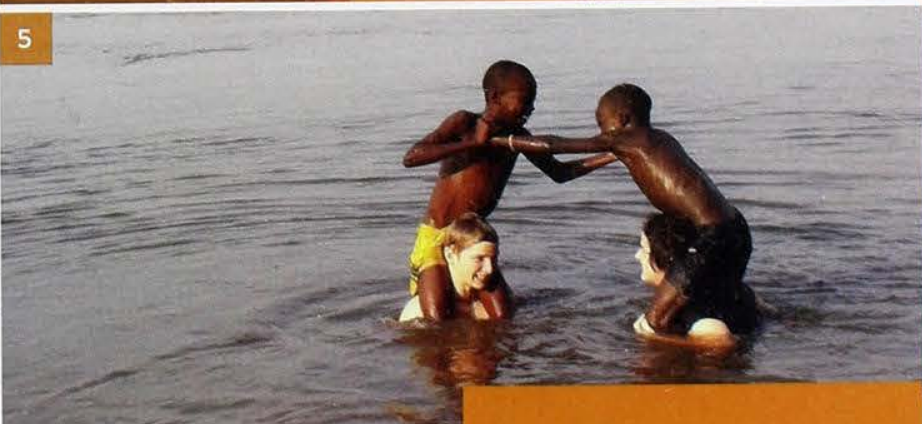

1. The sun sets on a beach in the Philippines behind a group of nursing students.

2. Sarah Mcculloch stands with her fellow team members in the Philippines.

3. Ella Kinsinger, Grace Revenaugh. and Victoria Myers smile with kids in the Republic of Congo.

4. Students travel to Paraguay for medical missions.

5. Sometimes, Jesus' love looks like a game of chicken in the waters of Congo. 

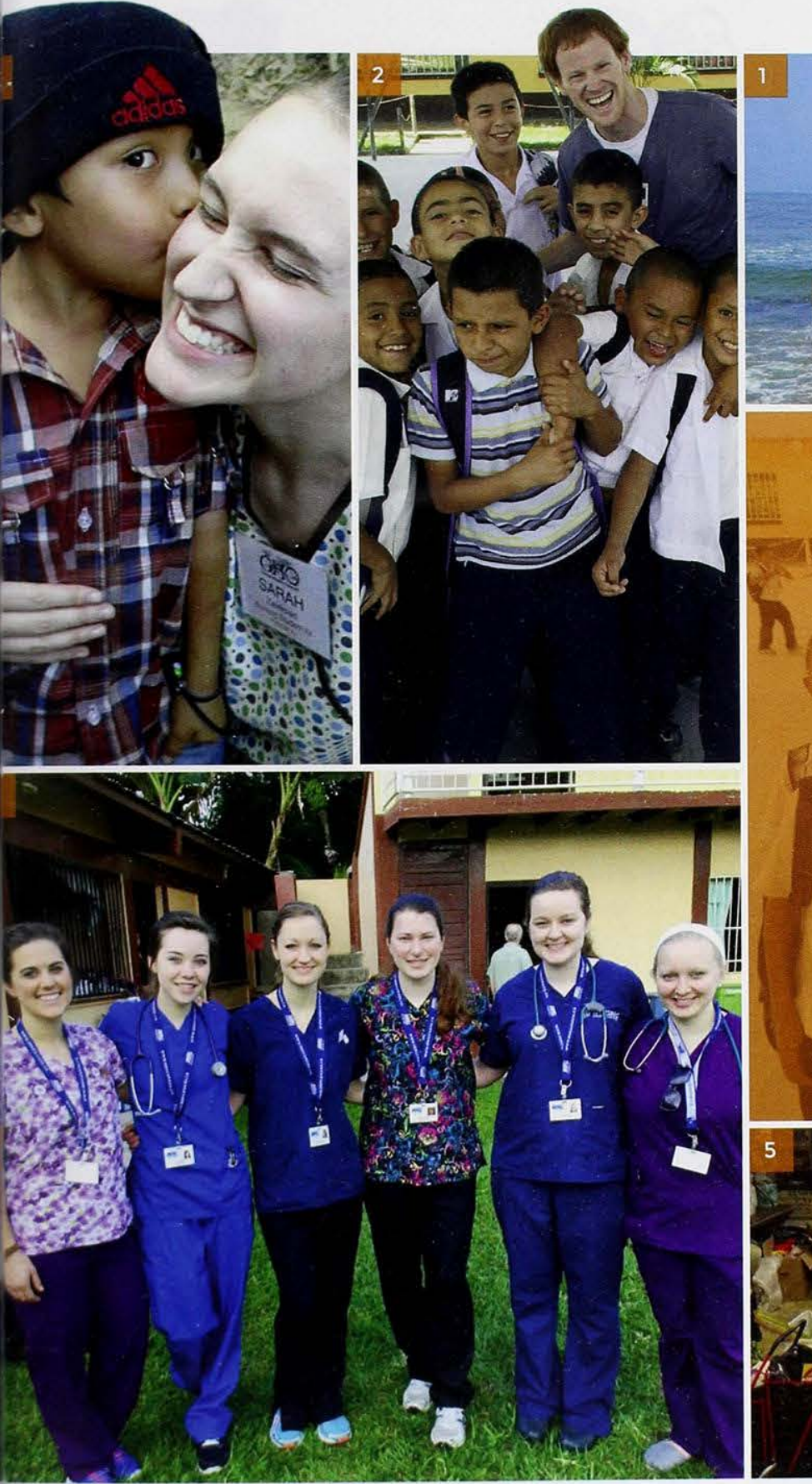

"My favorite part about Spring

Break in Honduras was being able to use what I've learned in pharmacy school to help treat people that needed medical help. Our group meshed so well together and became a family!"

Jonathan Wilkie

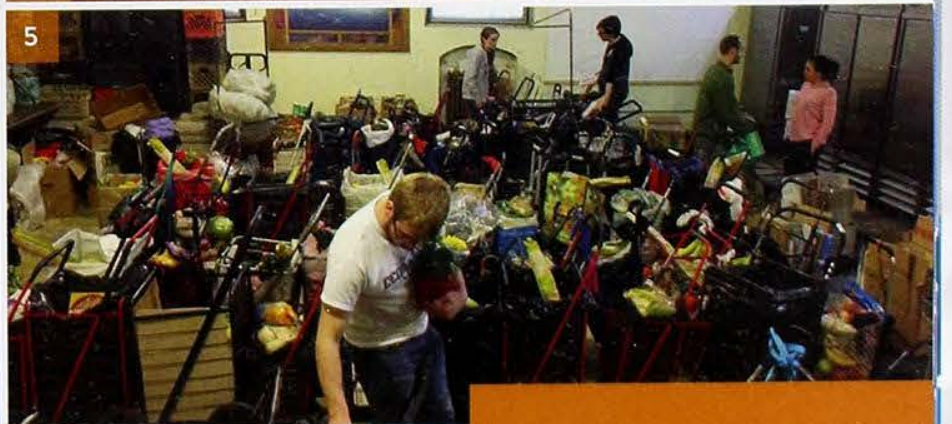

"I had the privilege of partnering with Cedarville and Global Health Outreach on a medical missions trip to El Salvador. We set up a clinic in a small village and medically served hundreds of people while sharing the Gospel. It was amazing to use my nursing skills and to share the Gospel with many hurting, broken people. The excitement the El Salvadorans displayed as they responded to the Gospel was incredible, and their joy was so encouraging! I was very blessed by this life-changing opportunity to show the love of Christ through medical missions in El Salvador!"
2. Jon Wilkie laughs with rough-housing boys in Honduras.

3. Sarah Zwirkoski accepts a kiss from her friend in El Salvador.

4. The team dons their scrubs while on a medical missions trip in Honduras.

5. The NYC team help pack grocery carts. 

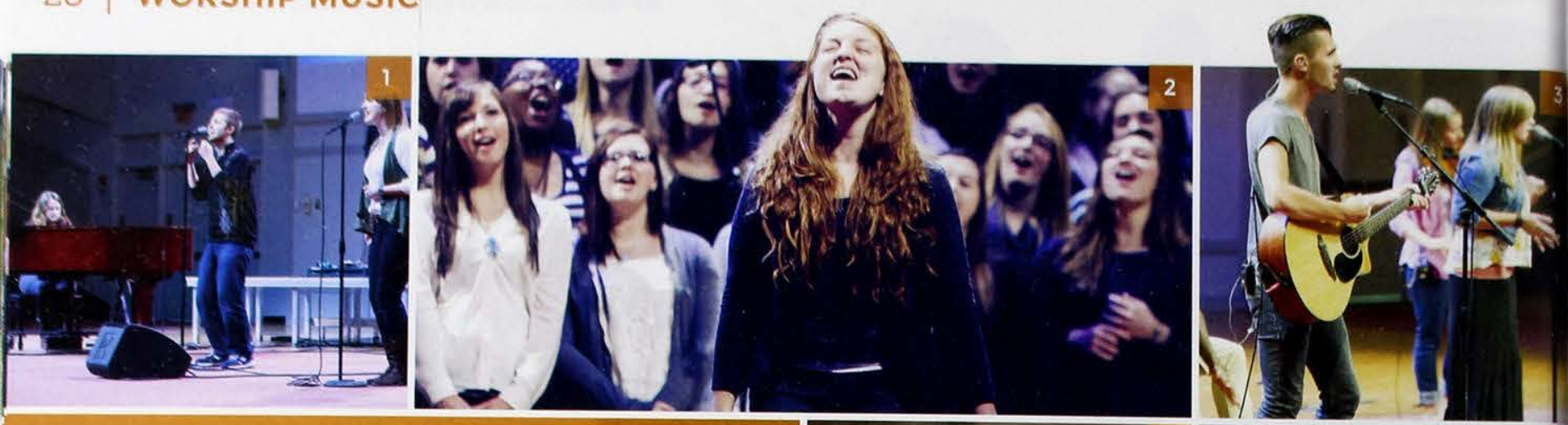

"During my time at Cedarville, I

was blessed to be able to serve

my fellow peers through music

and worship. Not only was it an

absolute joy, my experience as a

worship leader also helped me to

become a better leader."

Aaron Mittelo, Senior
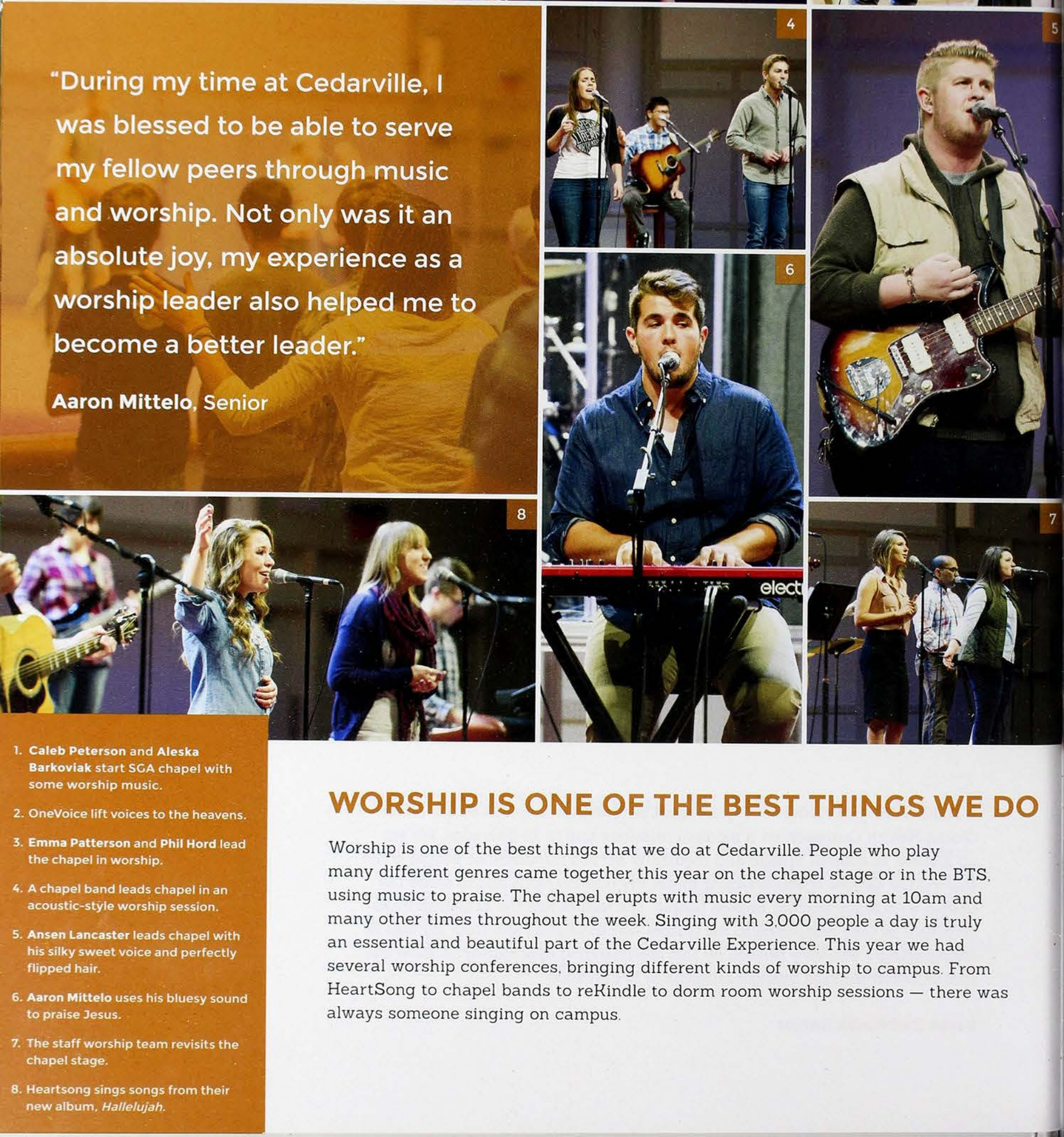

WORSHIP IS ONE OF THE BEST THINGS WE DO

Worship is one of the best things that we do at Cedarville. People who play

many different genres came together this year on the chapel stage or in the BTS,

using music to praise. The chapel erupts with music every morning at 10am and

many other times throughout the week. Singing with 3,000 people a day is truly

an essential and beautiful part of the Cedarville Experience. This year we had

several worship conferences, bringing different kinds of worship to campus. From

HeartSong to chapel bands to reKindle to dorm room worship sessions - there was

always someone singing on campus. 


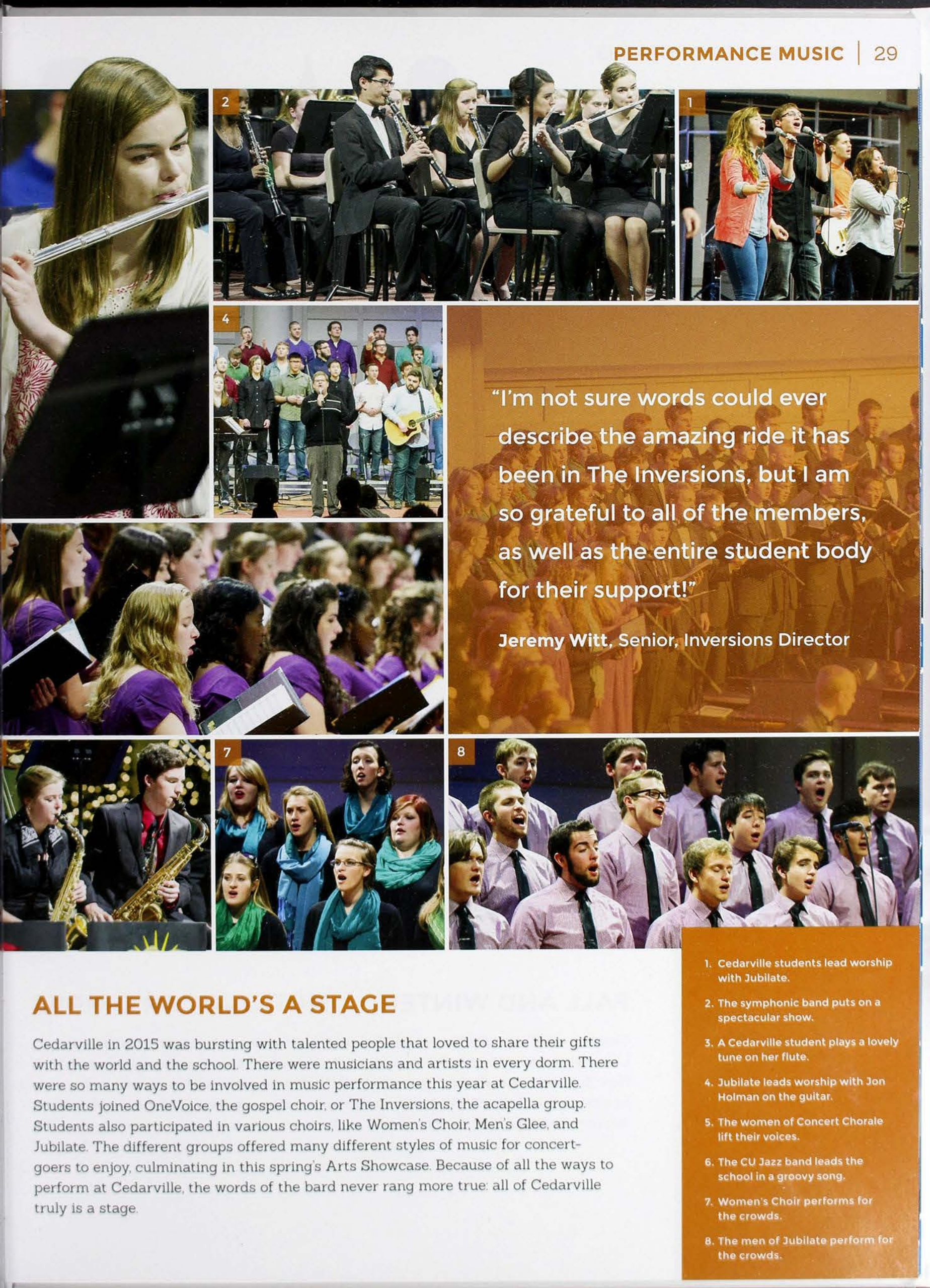



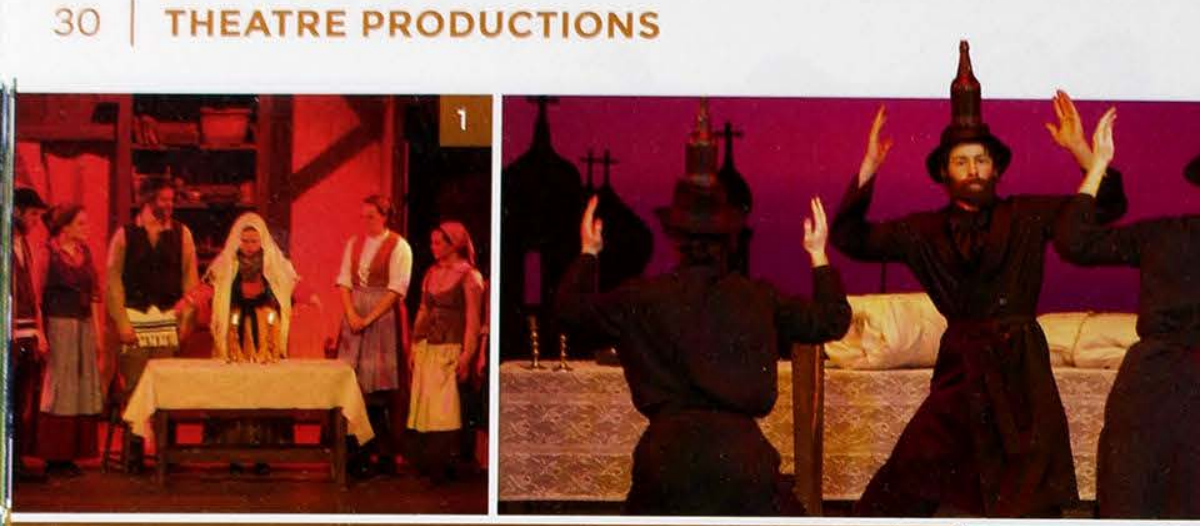

"Each production has stretched me as an actor and a human being. I've learned such valuable lessons to improve my craft, but I've also grown in how I perceive others and myself. I m amazed by God's redemptive work through our meager attempts at story-telling."

Emma Kowatch, Sophomore
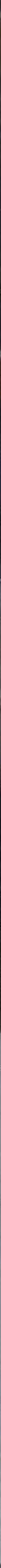

8
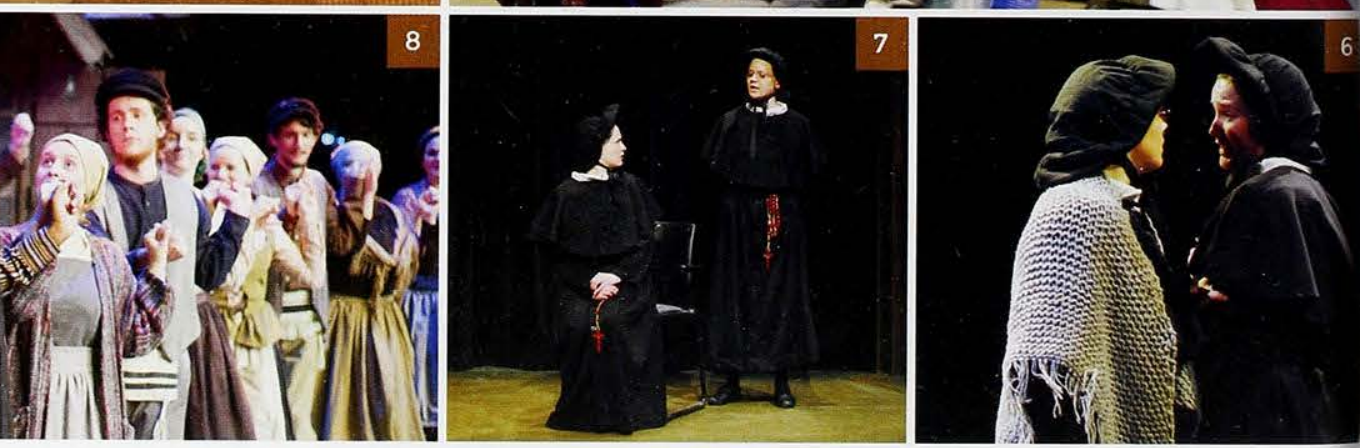

\section{FALL AND WINTER}

This fall, the Cedarville University Theatre Department produced Little Women, based on the novel by Louisa May Alcott. A show about four sisters growing up in New England in the nineteenth century, Little Women gave the department a chance to showcase its talent. With its universal themes of family, love, grief, and hope, Little Women proved to be a favorite among audiences. 


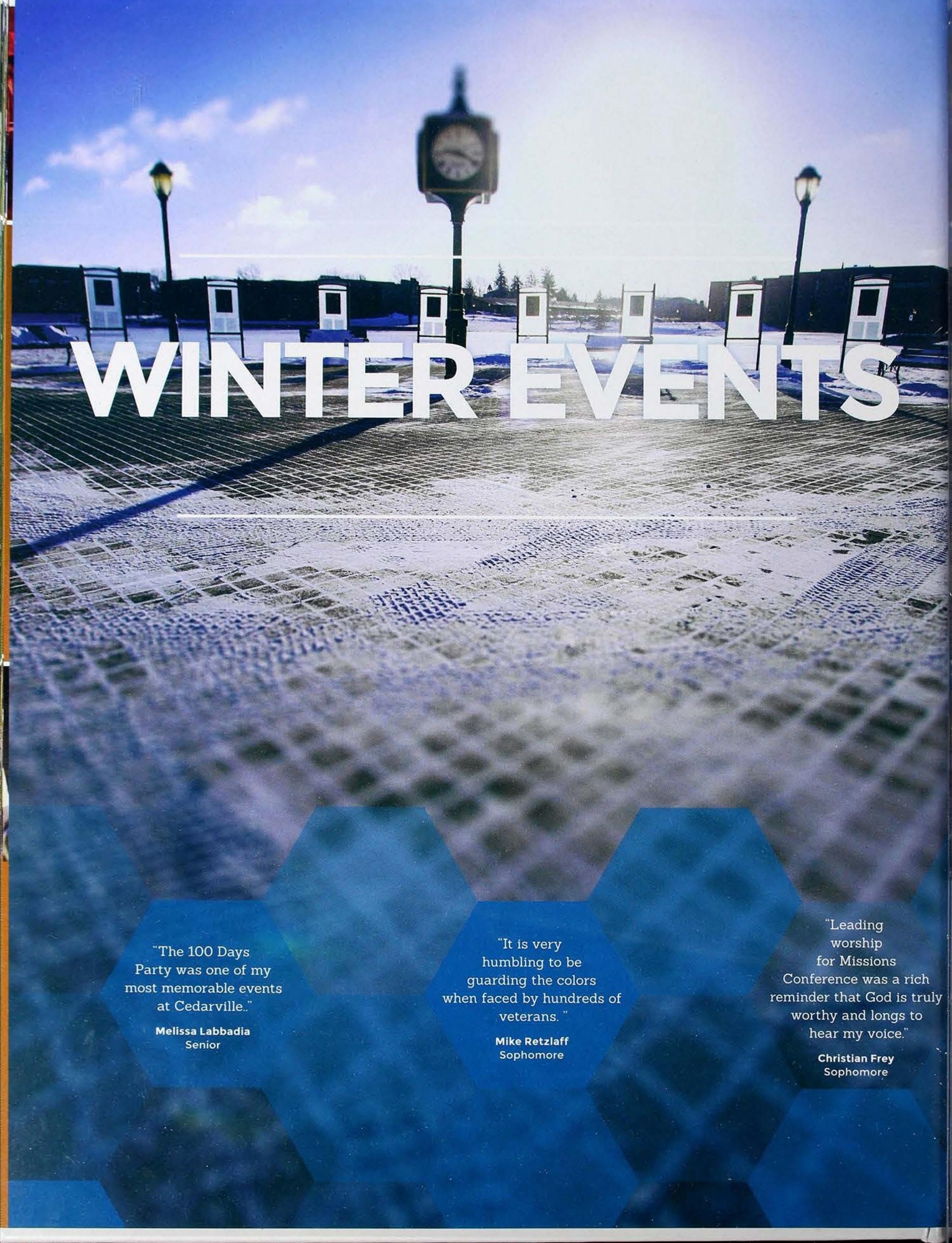




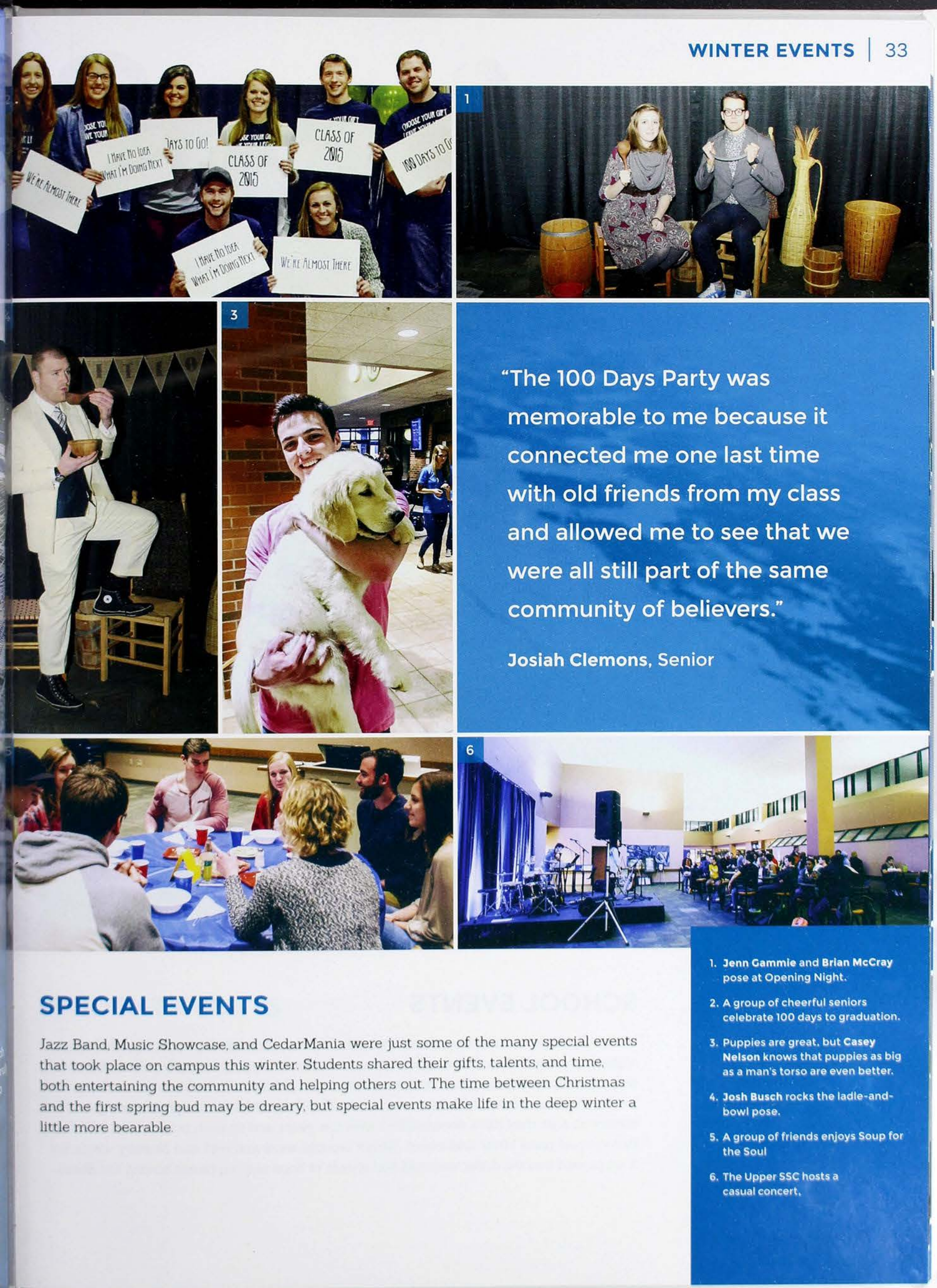




\section{WINTER EVENTS}

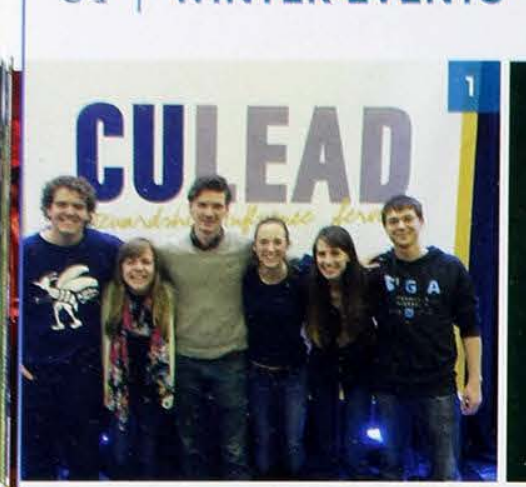

\section{"The 100 Days Party was a ton of fun! It}

was a great time for our class to come together and celebrate our past four years at Cedarville. For myself and those who were involved in planning the event, it was very exciting to see

\section{so many familiar faces again and} hear where and what everyone was planning for after graduation."

Phil Hord, Senior

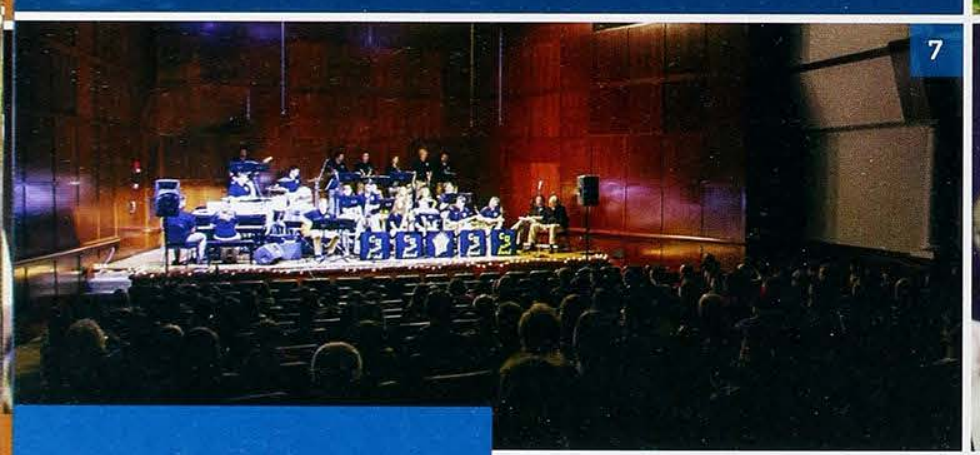

1. Current and future campus leaders enjoy the CU Lead Conference.

2. D.A. Carson preaches during chapel.

3. Missions Conference guest JD Greear speaks during chapel.

4. ROTC members present the colors at Veteran's Day Chapel.

5. Christian Frey leads the chapel in worship.

6. The orchestra plays as part of Music Showcase.

7. The CU Jazz Band serenades an audience.

\section{SCHOOL EVENTS}

Winter Spirits start to slump into snowbanks unless someone comes along and brings a glimmer of sunshine. Cedarville tried to remind us with inspiring chapels that the sun will shine again. In Missions Conference, we were told that we could do great things and be the hands and feet of Christ in the world. The Seniors had a moment to cling to the memories that they have accumulated over the years and to each other at the 100 Days Party, equal parts bitter and sweet. Winter brought snow and cold and blustery winds, but if we peeked into the drifts, we could find shards of hope and happiness among the flakes. 

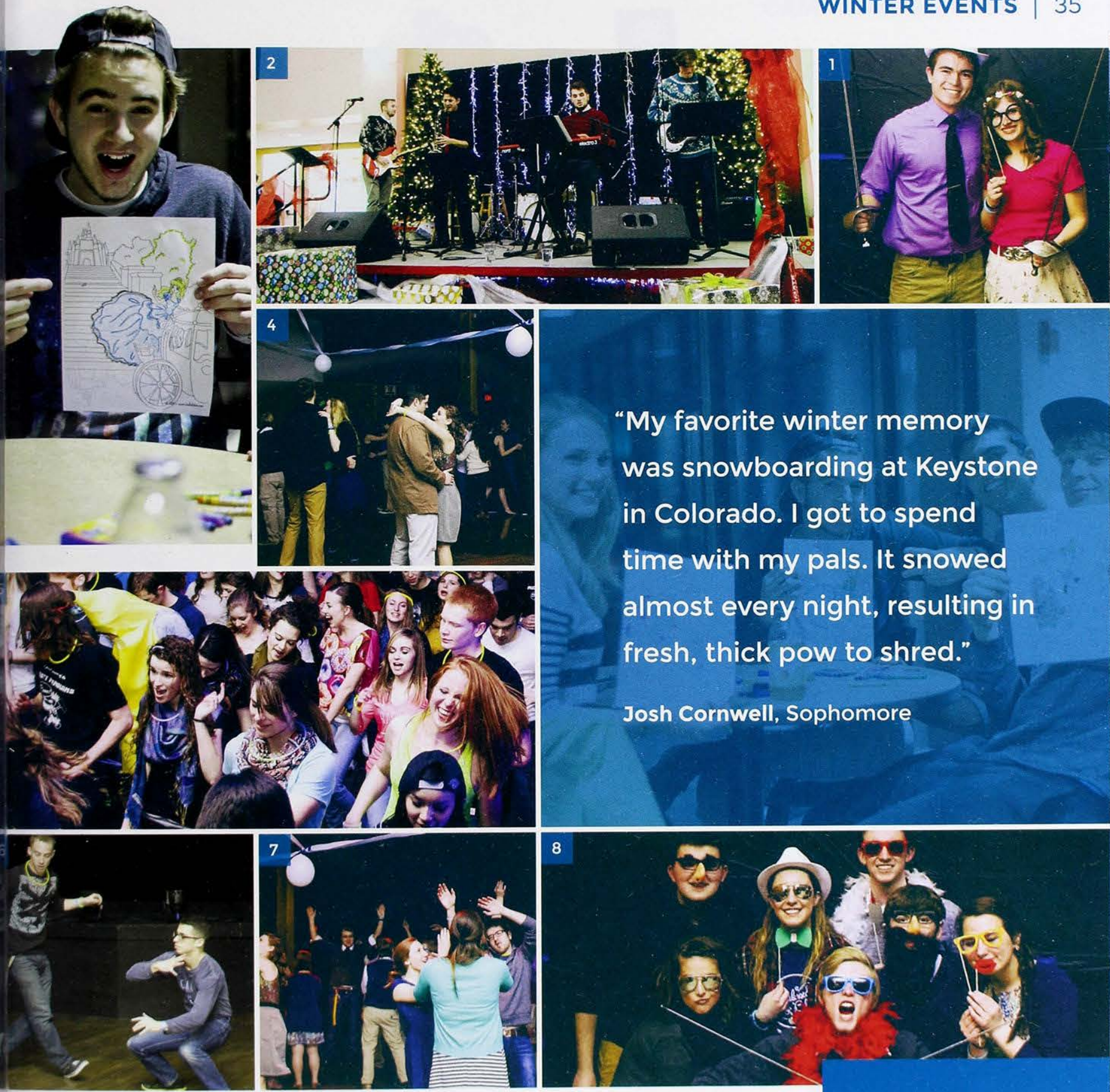

“My favorite winter memory

was snowboarding at Keystone

in Colorado. I got to spend

time with my pals. It snowed

almost every night, resulting in

fresh, thick pow to shred."

Josh Cornwell, Sophomore

\section{STUDENT EVENTS}

We threw on our khaki pants and went to the Sadie Hawkins dance, among other events, this winter. Students supported Makarios with dances and ALT Nights, sporting our Mak Tees. We had the chance to dress up to the nines for Opening Night. SCAB.

SGA, and various orgs kept life busy for students this winter 

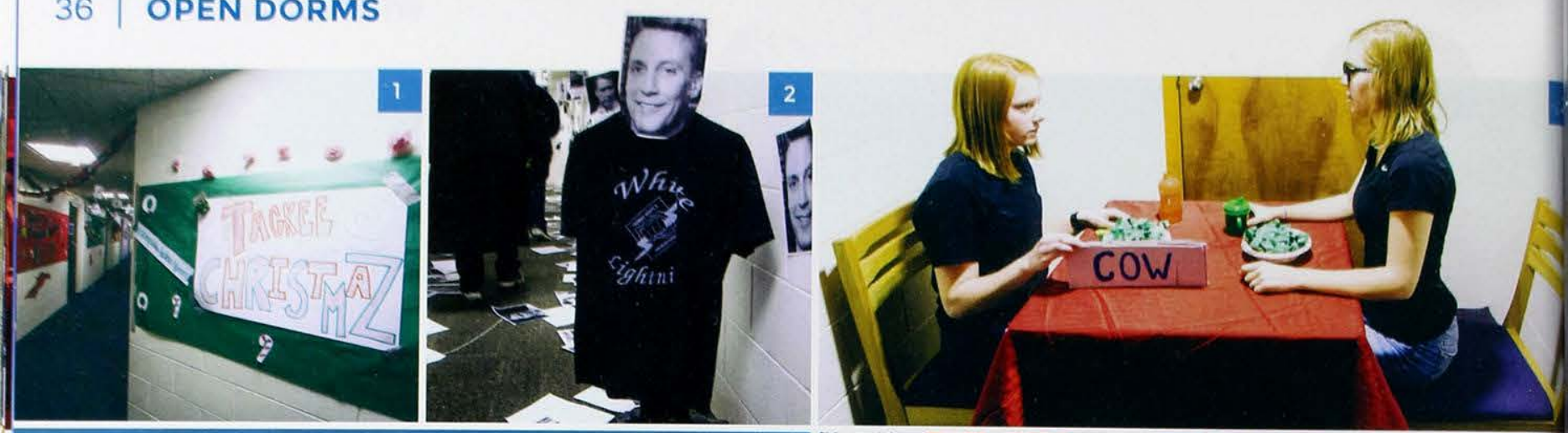

\section{"Open Dorms are great for playing} games and hanging out in a more comfortable environment! The last open dorms we watched Jeopardy and had a fight with moon sand. We spent most of the time cleaning up the sand."

\section{Sarah Bruce, Senior}

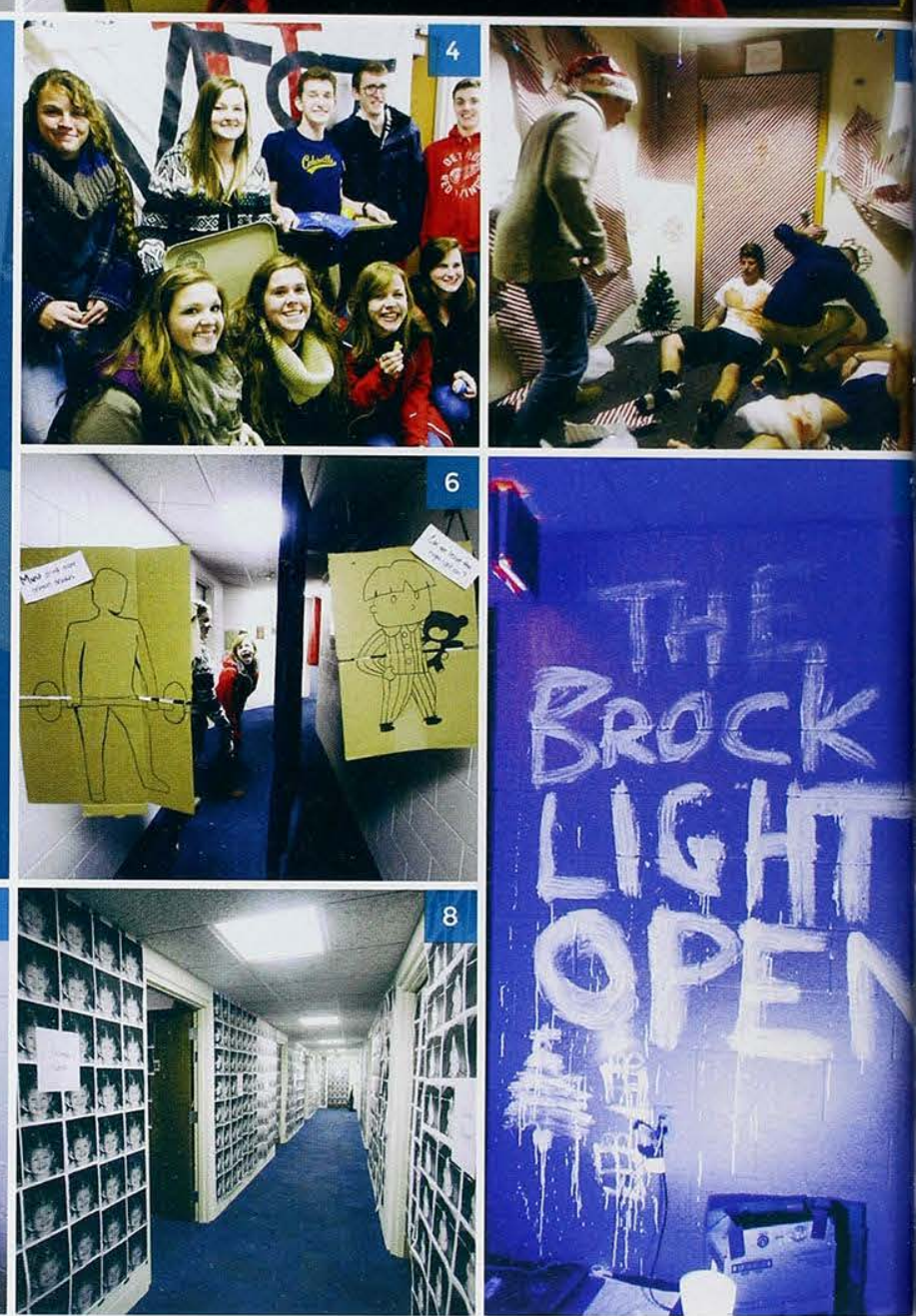

1. Welcome to McKinney's Tackee Christmas!

2. A terrifying number of Dr. Whites greets students as they enter this hall.

3. A Printy unit recreate popular YouTube videos for their Christmas Open Dorm.

4. A group of friends enjoys Campus Christmas Open Dorms.

5. -Season's Bleedings!" Love, Lawlor.

6. St. Clair gets creative when they build a Choose Your Own Adventure hall.

7. Rarely lacking in creativity, Brock men create a black light open golf tournament.

8. In case you ever wanted your embarassing baby photos plastered on the walls - don't worry, Johinson's got you covered.

\section{CHRISTMAS ON THE CAMPUS}

Open dorms were the time at Cedarville to cram as many people as possible into a stinky Lawlor room to watch a movie that would be completely ignored by everyone talking. They offered a different kind of fellowship than typical at Cedarville, as well as inducing panic by $400 \%$ if someone was so unlucky as to forget and be in the shower and suddenly hear different voices outside the bathroom. Panic was also caused by the sudden realization that it had been several days since room-checks, the room had been reduced to a disaster area again, and "the sisters are coming in about ten minutes, so shove it all under the bed" Christmas open dorms were a unique chance to stand in the snow and cold for a few minutes of pure Christmas bliss. Some standouts this year were a gingerbread house construction site, a room covered in coffee sleeves from all over the world that had been collected over the past four years, a throwback to the darkness and heavy cologne that was a Hollister store, and a journey with Mario to find Princess Peach. However, those creative ones are great, but Im a fan of the ones that give me free coffee. 


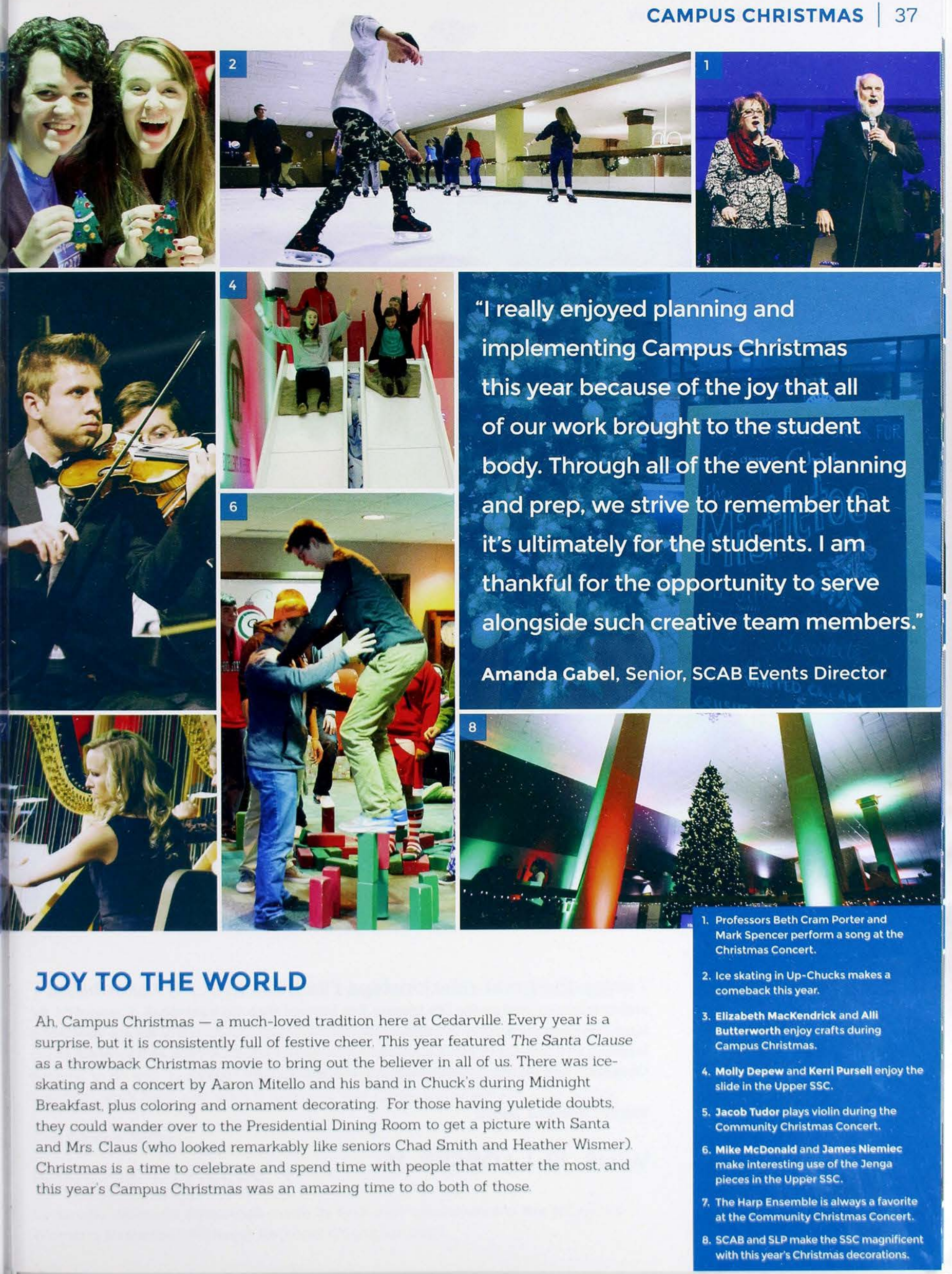




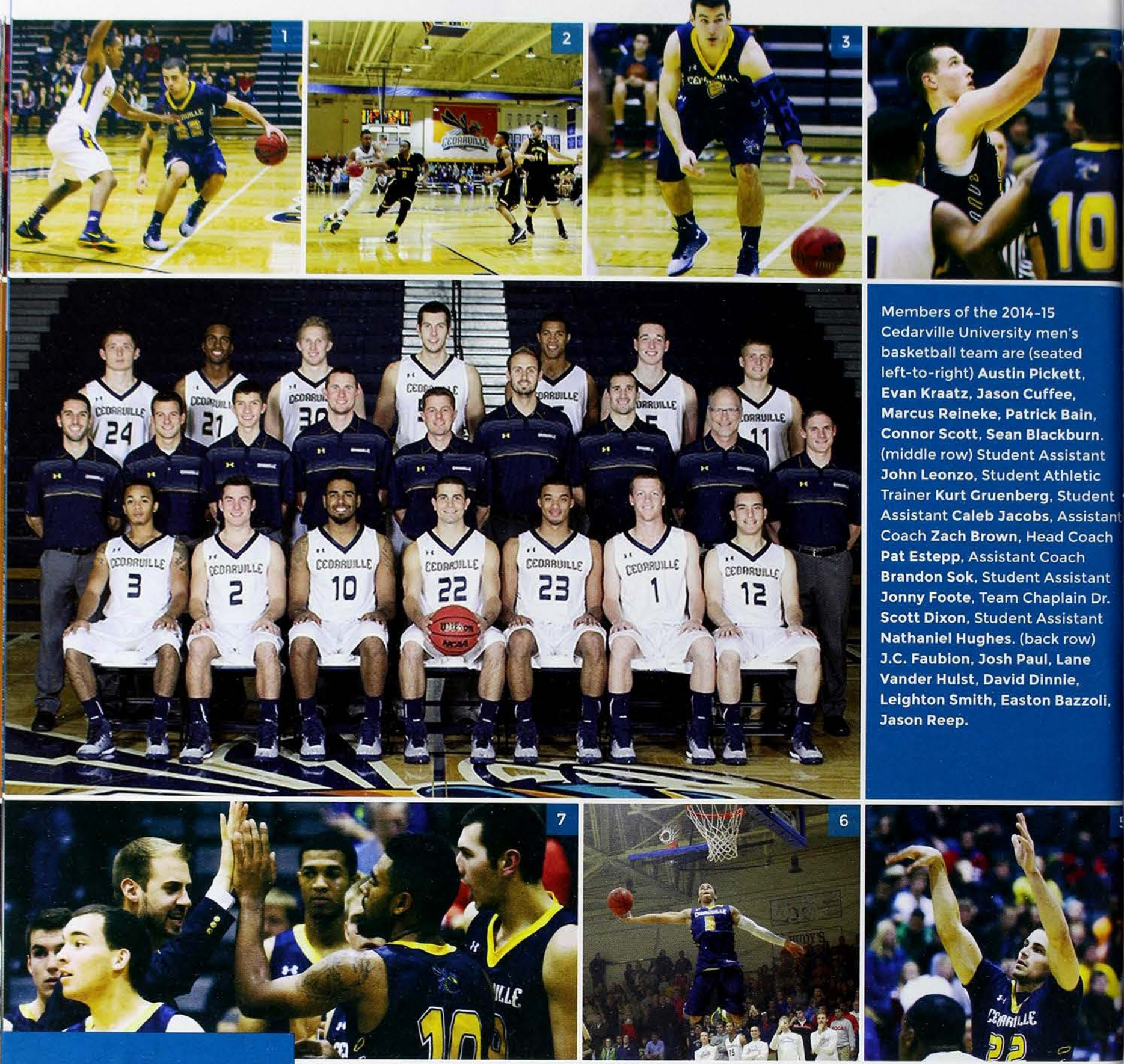

1. Marcus Reineke maneuvers around the opposition.

2. Jason Cuffee charges into a swarm of defenders.

3. Evan Kraatz looks for an open teammate.

4. Easton Bazzoli looks on as his teammate goes for a foul shot.

5. Reineke takes a shot.

6. Austin Pickett soars high for a dunk.

7. Jason Cuffee high fives Coach Brandon Sok.
"I enjoy the great relationships I've built with my teammates and coaches, as well as the life lessons I've learned through basketball. The season is long, and we go through a lot with each other; through the diversity we are constantly learning new lessons in life. It's rewarding because I will look back at my career at Cedarville and realize it molded me into the person I am today."

Marcus Reineke, Senior

WINS: 12 | LOSSES: 15 

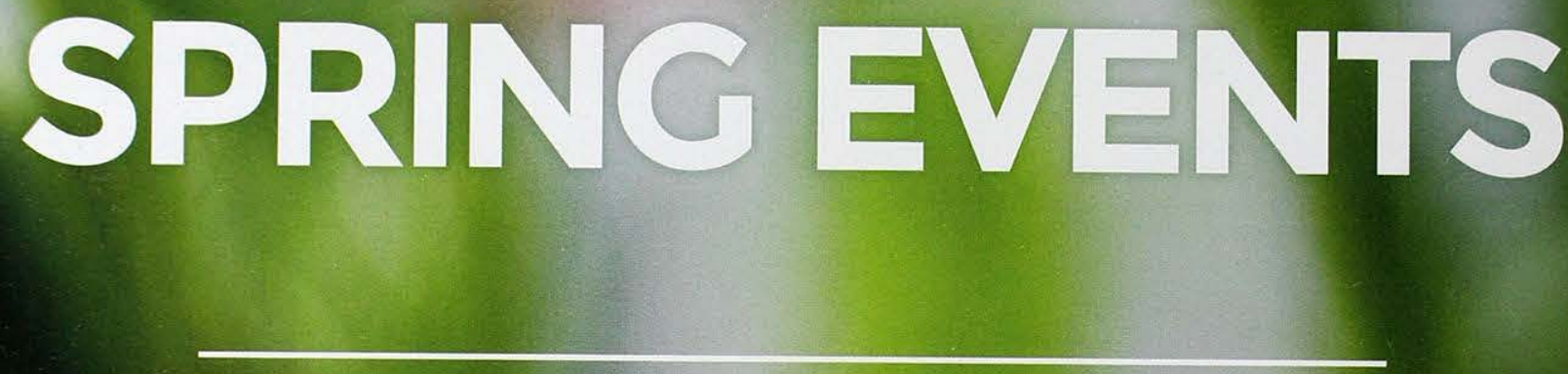

"I love the smell of rain and the promise of new life. Seeing everything go from death to life is a wonderful reminder of our life in Christ."

$$
\text { Peyton Green }
$$
Junior 


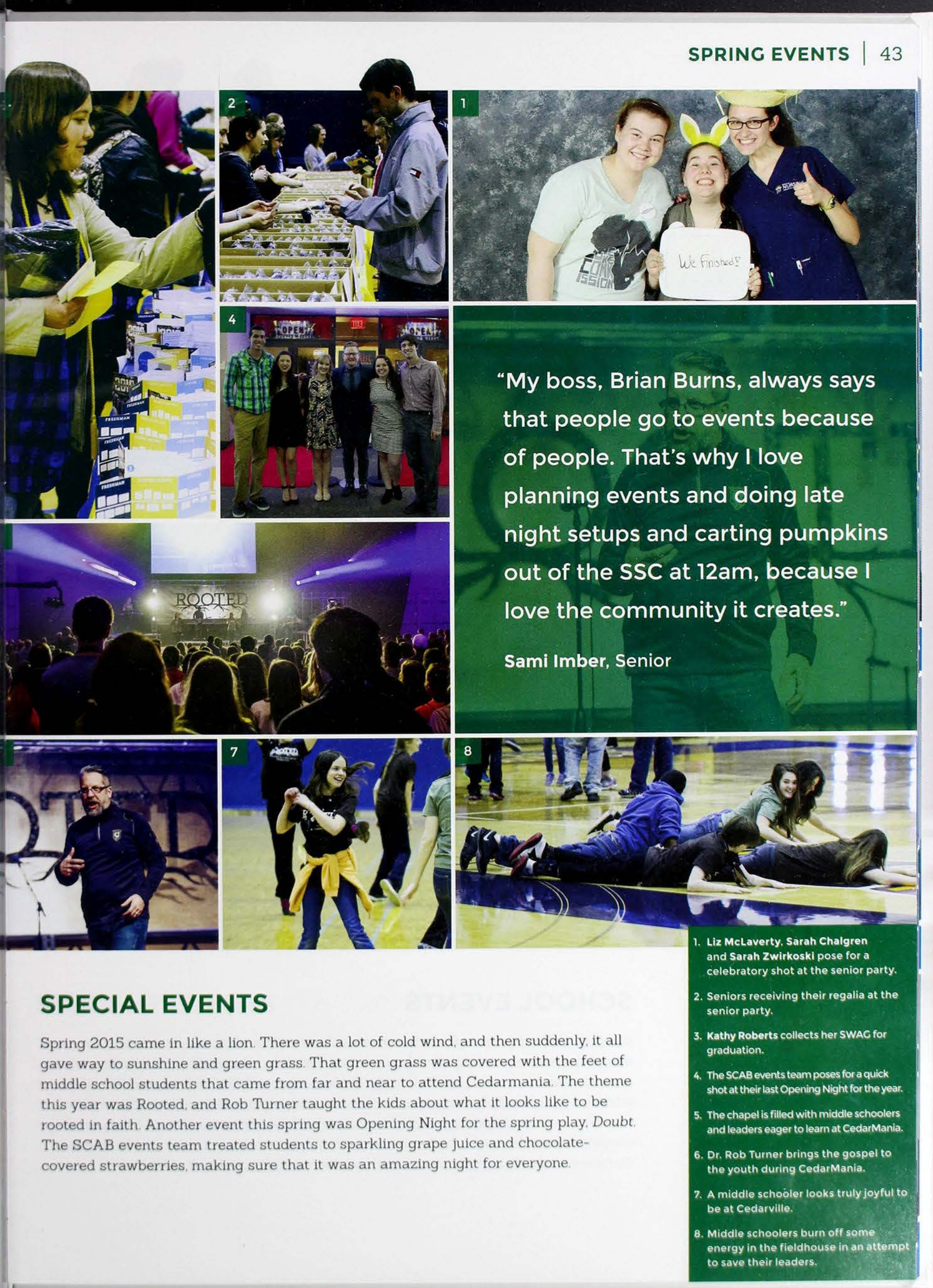




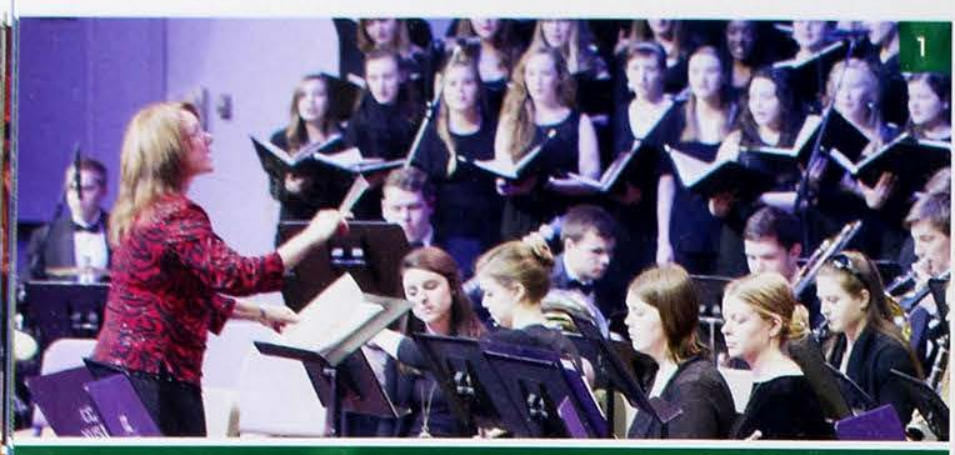

"Spring is such a wonderful time at

Cedarville because after five months

of ice and the coldest wind on earth,

you start to doubt if you'll ever be able to walk outside without a jacket again. There is something truly magical about not needing to scrape your car off in the morning anymore."

Jennifer Langton, Senior

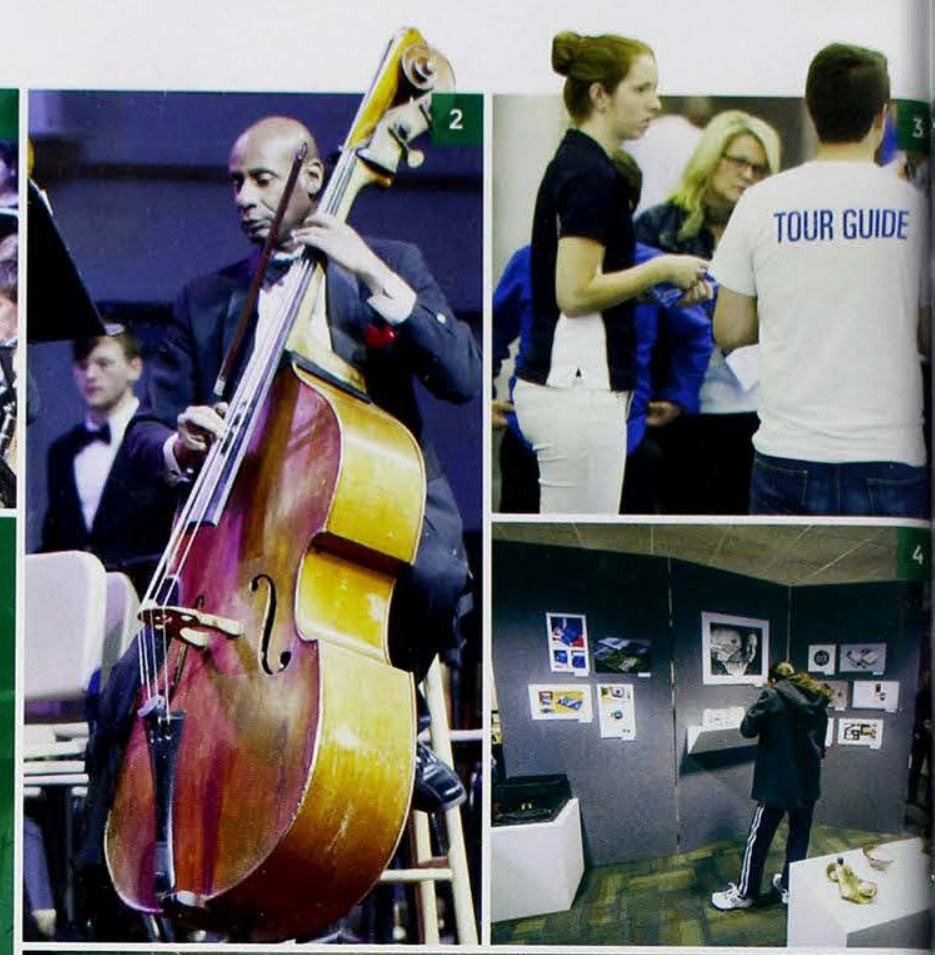

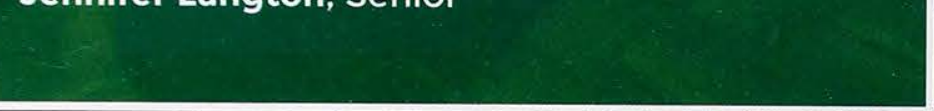
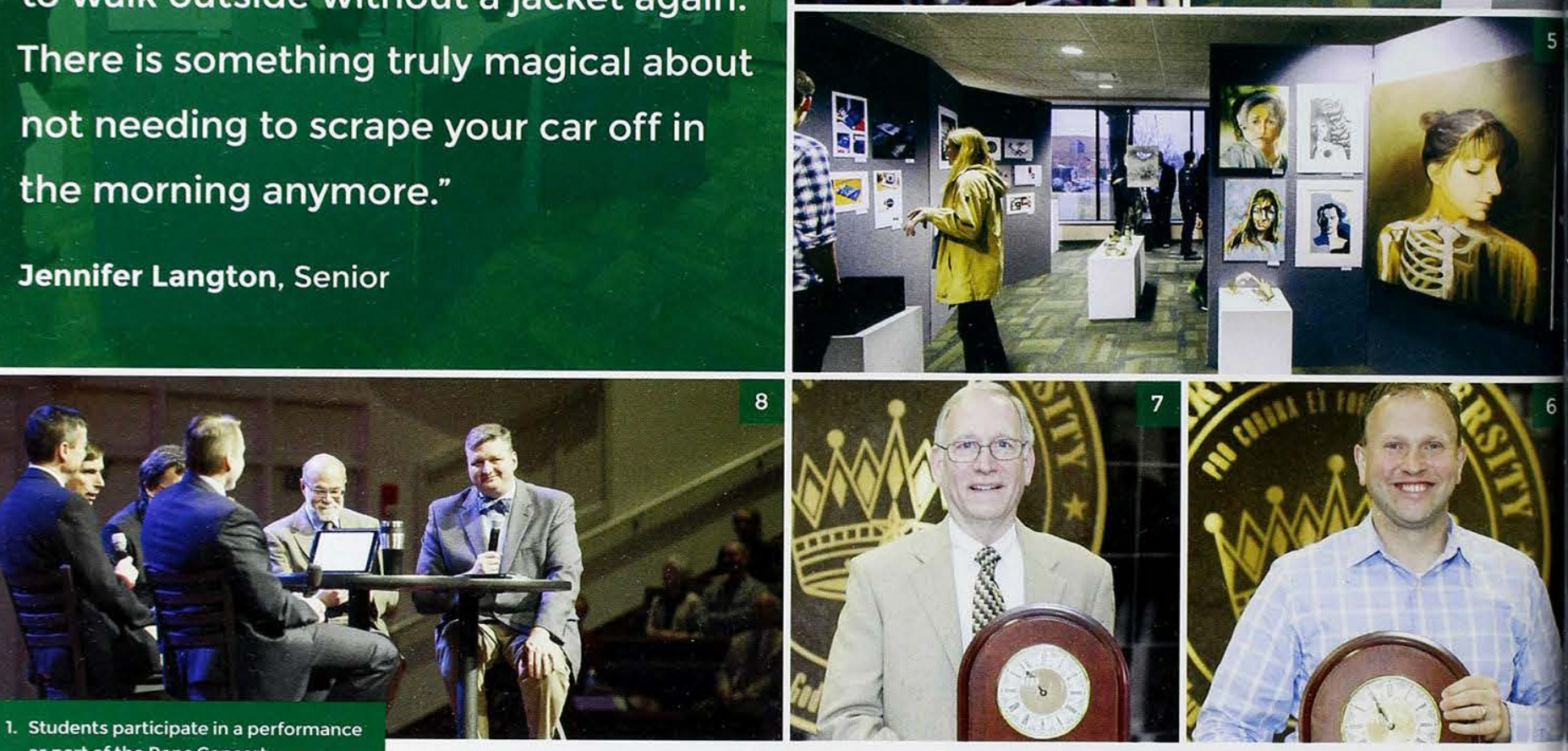
as part of the Pops Concert.

\section{SCHOOL EVENTS}

Grace Sincock and Ryan Frantzis lead a group of prospective students on a tour.

4. A student takes in a piece at the Juried Art and Design Exhibition.

5. Students discuss art on display in the Upper SSC.

6. Brian Burns was awarded the Staff Member of the Year Award.

7. The Faculty Member of the Year Award was awarded to Mark Klimek.

8. Dr. Mark Smith participates in a discussion with Bereans at the Gate in chapel.
Bringing tours of new students to see what Cedarville is, that new excitement for the end of the year, and the blooming pear trees with that odd smell that no one can quite explain - another spring at Cedarville. Students enjoyed JS, SoFresh, and ELLIV. They attended the spring play, concerts, and watched orgs on campus initiate their new members - featuring crazy costumes and awkward encounters. Events like special chapels and conferences challenged us to think about current issues and to celebrate members of the Cedarville family, both students and faculty/staff alike. 

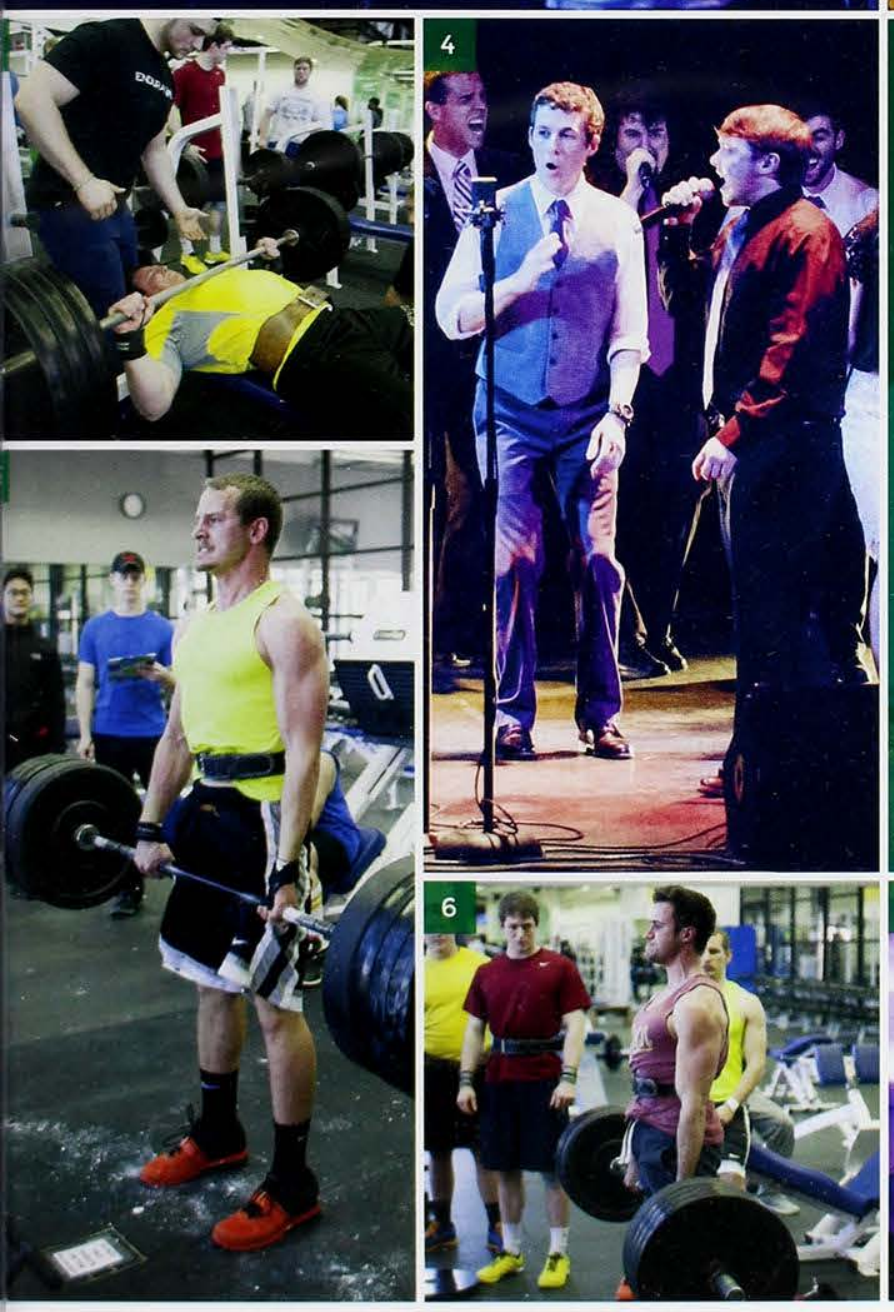

“Leading a worship band is such a unique blend of musicality, fellowship, and ministry. I love that it's an exciting and diverse vehicle to express our love and gratitude to God."

Emma Patterson, Senior, Leader of ReKindle

\section{STUDENT EVENTS}

This spring, Cedarville students put on some new, interesting events. The Mini Arnold lift competition allowed students to show off the strength they'd been working all year to obtain. There were also worship nights, which gave students the chance to worship God with their peers, led by their peers. Heartsong released a new CD, making us all hope that there is an angel in heaven that sounds like Michael Pettus. 

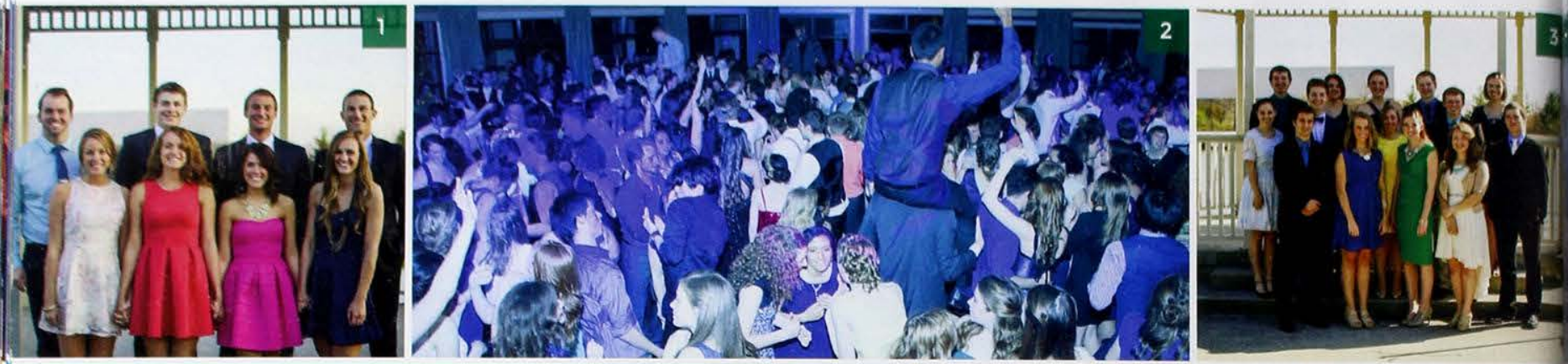

“My favorite part about planning JS

was that we weren't planning for ourselves - we were planning to meet the needs of others. It was awesome being able to give back to the Seniors and give them one big night to celebrate the past four years."

Evan Stark, Junior

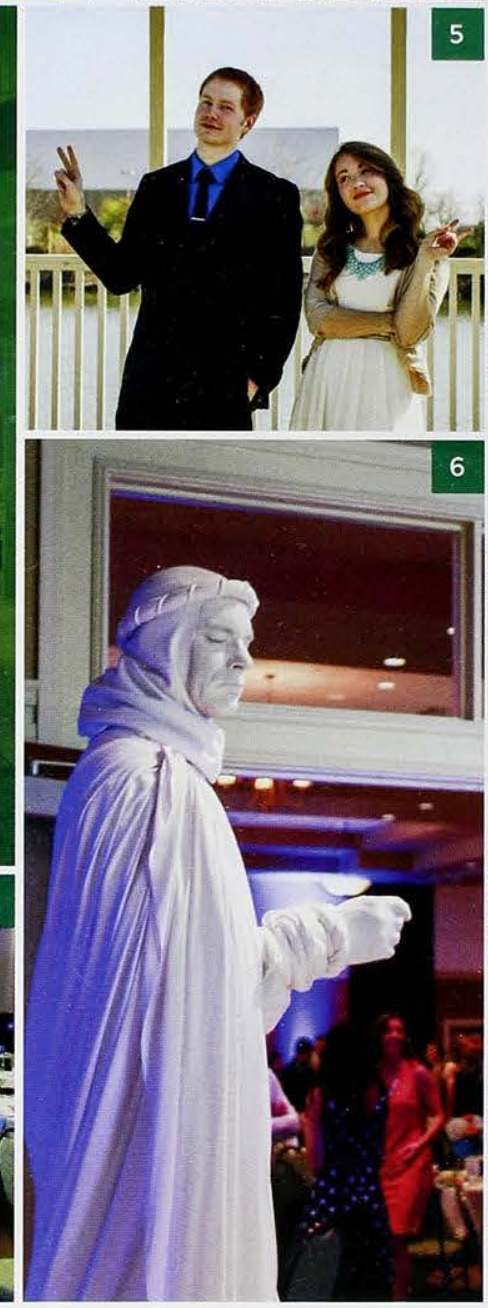

5

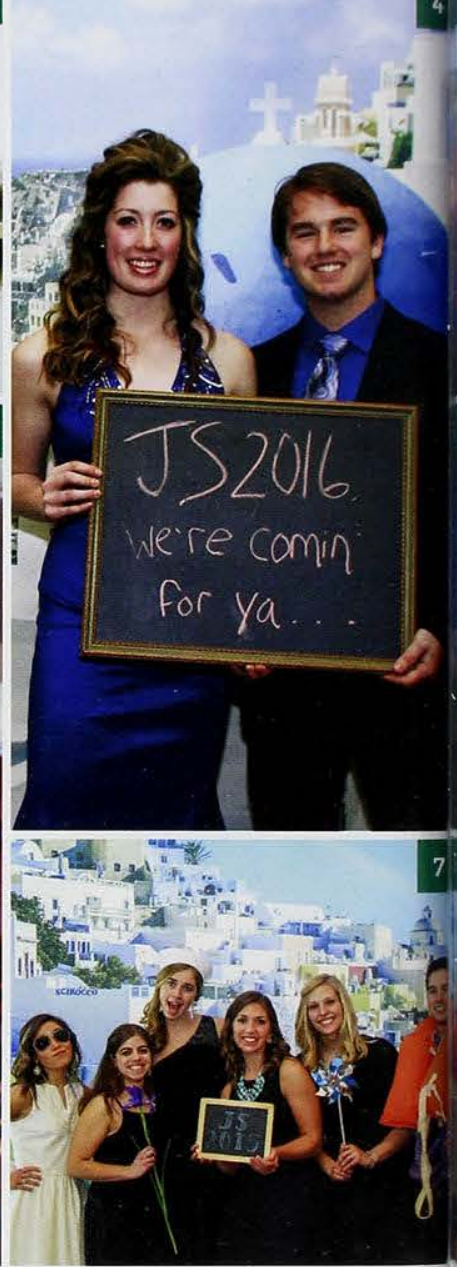
enjoy one last big night.

2. If JS teaches us anything at all, it's that Cedarville students know how to dance the night away.

3. The gazebo on the lawn on the Savannah Center served as a perfect pre-dinner photo op.

4. Taylor Buckley and Kenton UImer look forward to next year's event.

5. Andrew Spencer and JoHanna Sanders snap a photo before dinner.

6. Is this a statue, or a person? How brave are you?

7. Friends pose for a pic in the photo booth.

\section{THE GRANDE TOUR}

This year, the JS Committee took juniors and seniors on a getaway on the Mediterranean. Harkening back to the days when young men and women would travel the coastal countries as a rite of passage, the special night served as a reminder of the rite of passages seniors would soon face. The evening was a success, full of food, entertainment, and dancing for all. 
48 | ELLIV
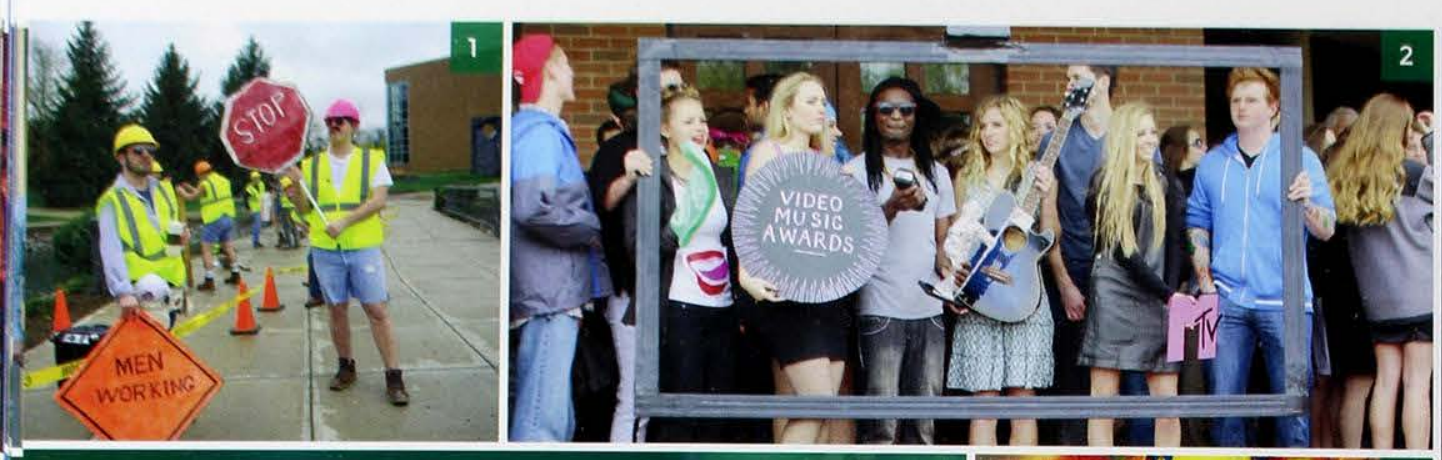

\section{"When the night of Elliv came and I was} able to see all of our hard work pay off, I learned that no matter how long and tiring the journey was, it was worth it. Elliv is something that has deeply impacted the student body, whether they are in the crowd, in the show, or winning an award voted on by their peers." Jenna Pretty, Junior

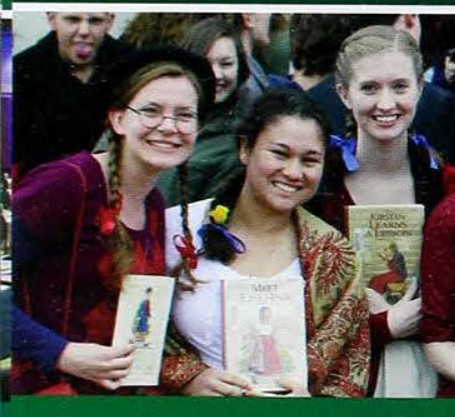

1. The winners of this year's costume contest were "Men Working:"

2. The "Video Music Awards" werea runner-up for Favorite Costume.

3. Caleb Peterson sings "Feelin' Good," which won Favorite Act at Elliv this year.

4. These Disney Princes and Princesses graced Elliv-goers with their presence.

5. Students sing as part of the "Ain't it Fun" act.

6. Abby Israel sings "Survivor" for her final Elliv performance as a student.

7. Brett Muschott plays guitar for a mashup of "Beautiful Soul" and "Check Yes, Juliet:-

8. Grace Littlefield, Alex Rivera, Katie. McKenna, Christine Nietert, and Erin Scott dressed up as our generation's favorite American Girl dolls.
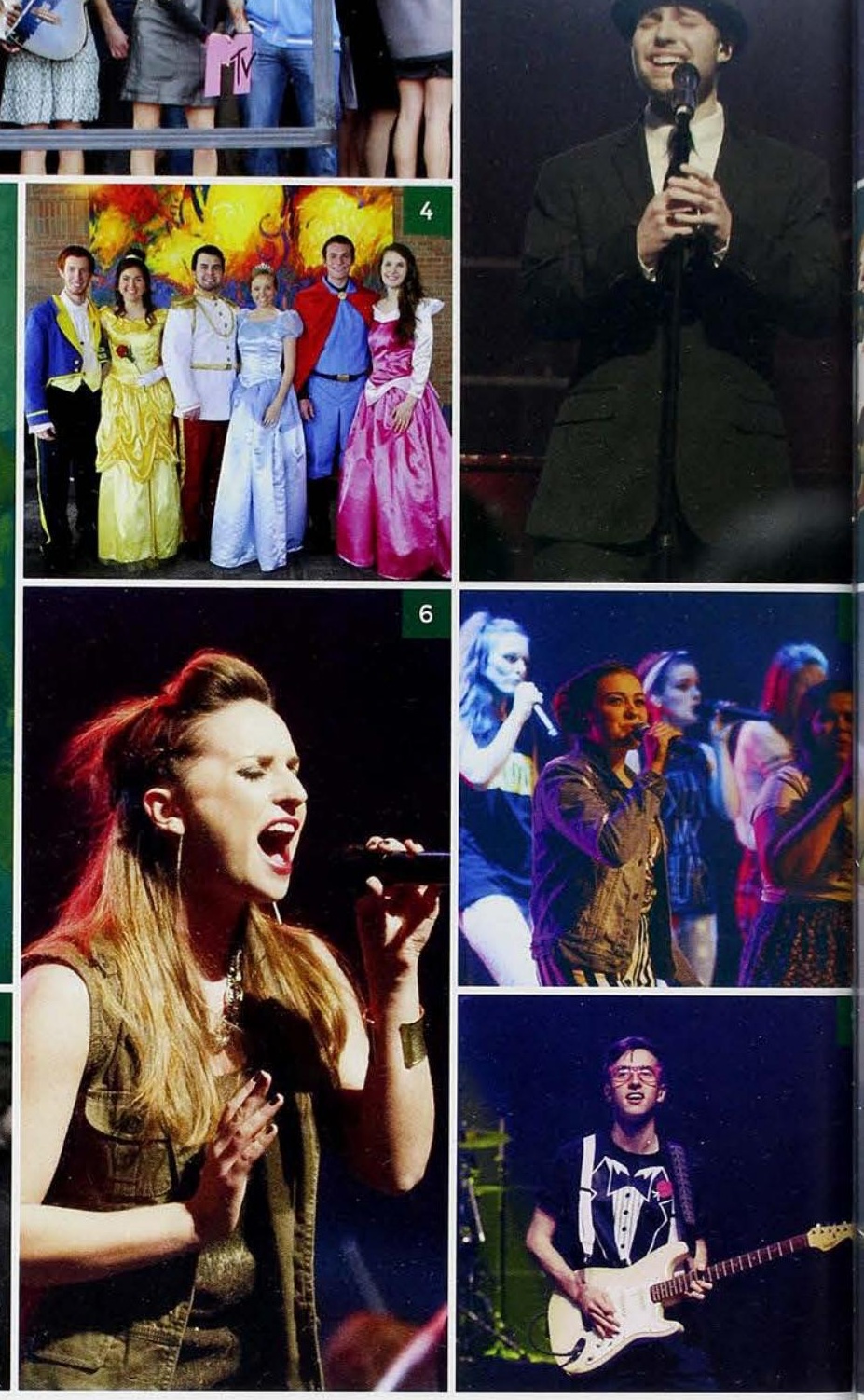

\section{REWIND}

Elliv was a blast to the past this year! Students, staff, faculty, and even alumni enjoyed a show packed with the greatest hits from the past fifteen years. From $\mathrm{N}^{*}$ Sync to Jesse McCartney to Adele, there was a little something for everyone. The theme, dubbed "Rewind," celebrated the last fifteen years of Elliv, which began as a studentled awards show spoof back in 2000. The event has grown to become the largest and most anticipated student event of the year, and for good reason. Complete with dancers, singers, and even a few slick guitar tricks. Elliv launched students into finals week with a bang. The show closed out with this year's hit "Shut Up and Dance" by Walk the Moon - the perfect anthem for the final week of school. 
54 BASEBALL
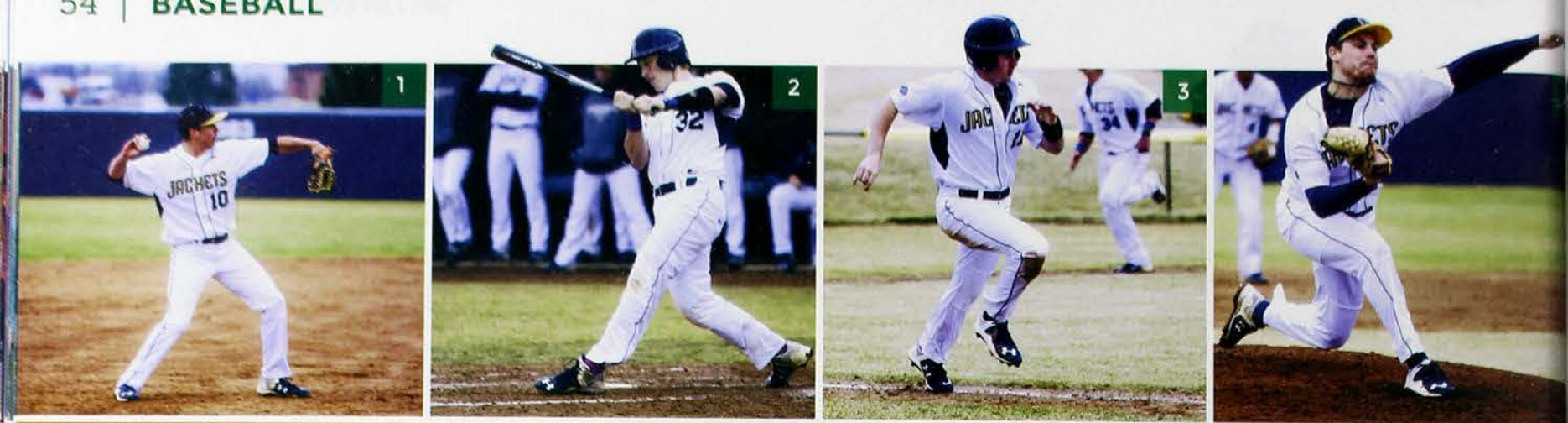

Members of the 2015 Cedarville University baseball team are (front row left-to-right) Jordan Adams, Joey Chapman, Nate Robinson, Colton Potter, Tyler Hurt, Marshall Johnson, Marc Russell, Thad Ferguson, Spencer Hutchinson. (middle row) Eli Weldy, David Bancroft, Nathan Bancroft, Garrett Baker, Zach Huskey, Sean Larkin, Steve Cardwell, Sam Summerlin, Jorda Ammon, Peter Martin, Connor Hamilton, David Lenhardt. (back row) Head Coach Mike Manes, Jesse Bush, Josh Kneeland, Joel Blodgett, Drew Johnson, Harrison Martin, Jaden Cleland, Cole Swigert, Jesse Froese, Evan Sutton, Student Assistant Julio Miranda, Assistant Coach Ben Galbreath. (Not pictured: Assistant Coach Randy McKinion Scott Kneeland)
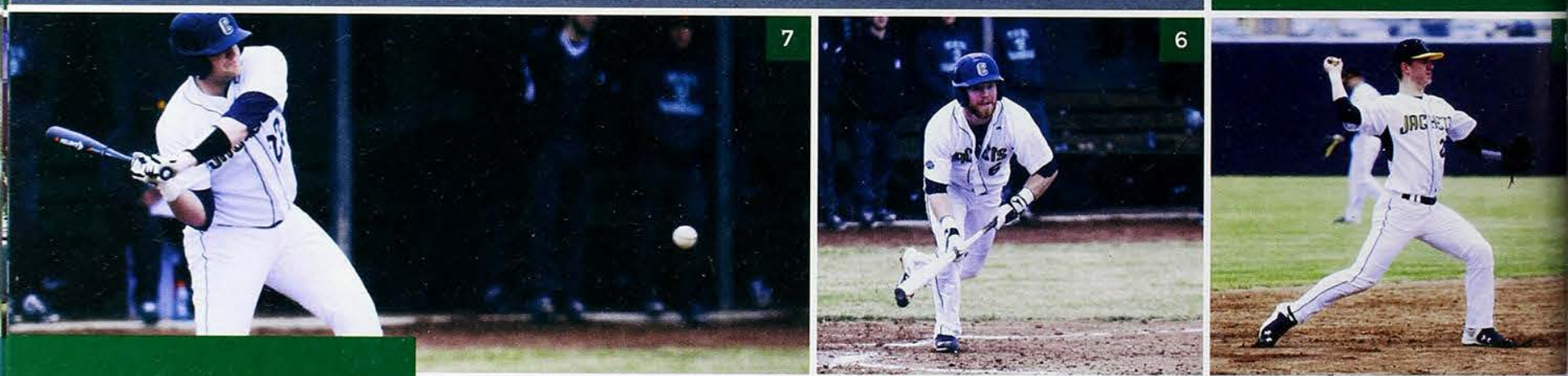

1. Drew Johnson searches for an open teammate.

2. Jaden Cleland hits the ball.

3. Joey Chapman and David Lenhardt make a run for the next base.

4. A pitch from David Bancroft.

5. Marc Russell launches the ball to a teammate.

6. Sam Summerlin races for first!

7. Steve Cardwell takes a swing.
"Being able to play varsity baseball at Cedarville is a huge privilege. Not only do I play alongside talented teammates, but I've also made great friends that I hope to have for a lifetime.

Evan Sutton, Sophomore

WINS: 21 | LOSSES: 26 


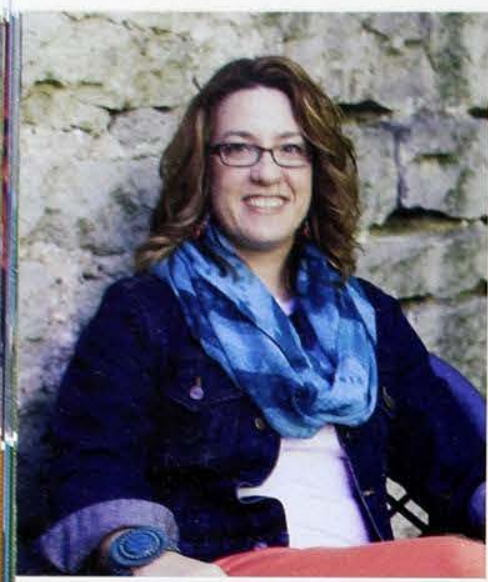

Cynthia Messer

Faculty Advisor

Cyndi is an associate professor of English and has been the faculty advisor for yearbook for fifteen years. She teaches composition, literature. grammar, and methods courses She is the program coordinator for the AYALA major and enjoys working with future English teachers. She also enjoys spending time with her three children and husband of twenty years.

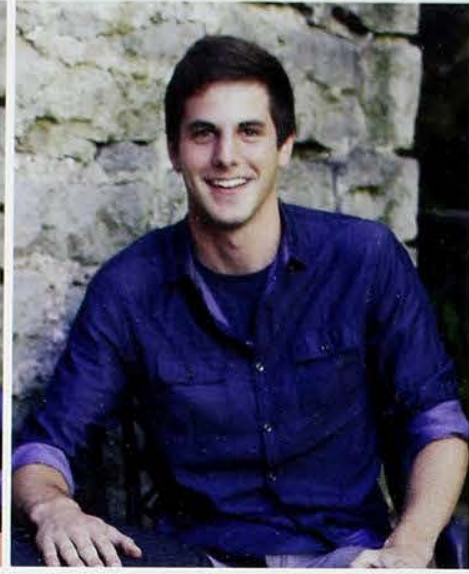

David Wright

Editor-in-Chief

David is a senior information technology management major from Fremont, $\mathrm{NH}$. This is his second year working with the Miracle Yearbook as Editor-inChief. He has enjoyed the privilege of working with an extremely talented staff and would like to thank his editors and the rest of the Yearbook staff for their hard work this year.

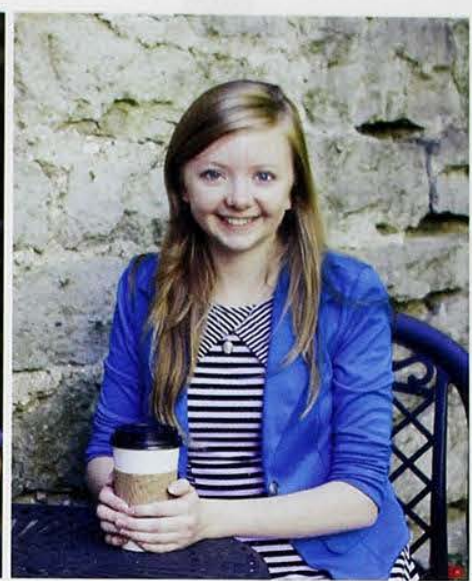

\section{Courtney Raymond} Copy Editor

Courtney is a senior applied communications major from Salem, $\mathrm{OH}$. This is her second year as copy editor. Courtney enjoys stories in all forms, writing, and being involved in theatre. Someday she hopes to teach at a university, publish some poems, and perhaps be a librarian. She is incredibly grateful for Jenn Langton and all her hard work as copy assistant. courtneyraymond.wordpress. com

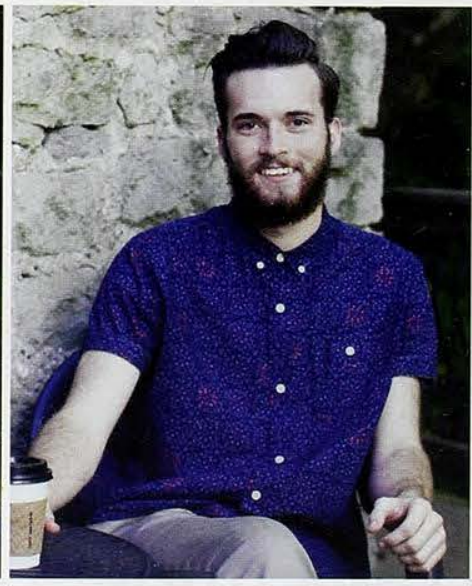

Peyton Green

Layout Assistant

Peyton is a sophomore graphic design major from Lewes.

Delaware. He is an avid air breather and coffee taster. He also loves being creative and designing, both of which he gets to do in yearbook. He is thankful for the opportunity to work on yearbook and is looking forward to continuing to work for them next year

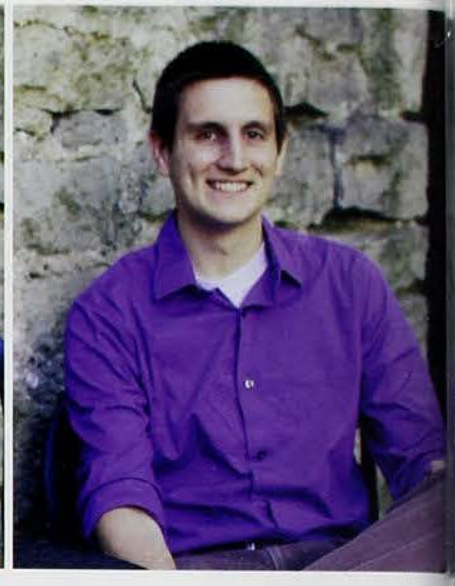

Maitland Gray Layout Editor

Mait is a senior graphic design major and web design and marketing minor from Hudson, Ohio. His second year working with the yearbook staff has been a great experience. Layout design is an area that he has always enjoyed. He would like to pass on the role of layout editor to Peyton Greene and thank him for all his work on the yearbook.

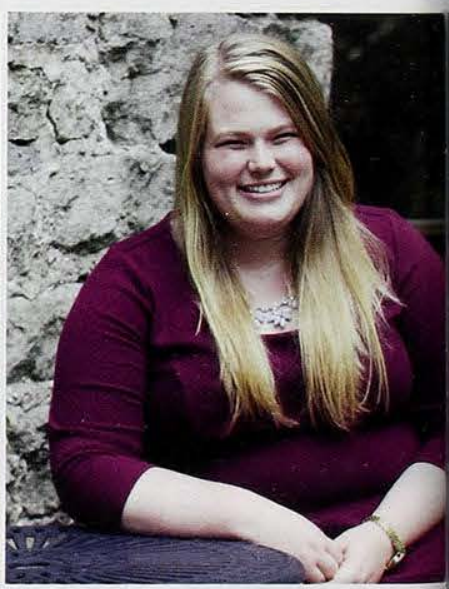

Jennifer Langton

Copy Assistant

Jen is a senior social work major from Cadillac, Michigan. She loves writing and making people smile and how she can do both of those through the yearbook. She has loved working as Copy Editor Assistant with Courtney for the past two years and is looking forward to her future after graduation

shoutforhisglory.blogpost.com 


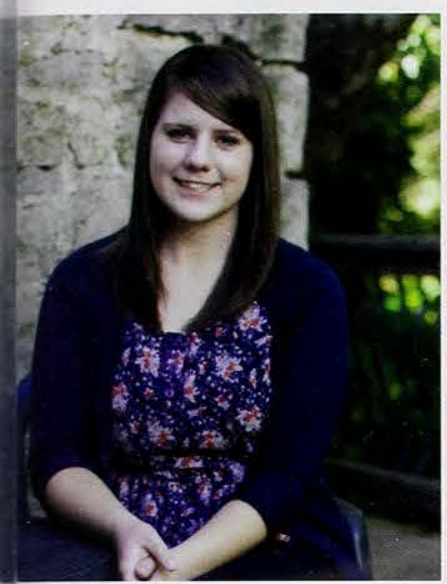

Jillian Philyaw

Shotography Editor

illian is a senior graphic design najor and web design minor

rom Peoria, IL. This is her third rear working with yearbook and irst year as photography editor. Jillian has loved working with Kyria and Tianle this year, and she would like to thank them or their dedication to providing quality photos for yearbook.

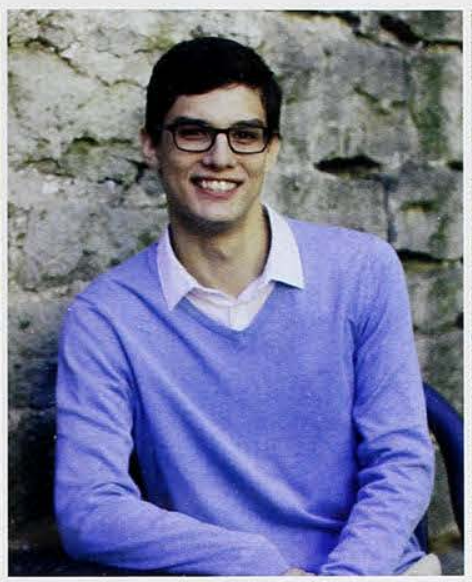

Ricardo Casteñeda

Marketing Director

Ricardo is a Senior marketing major from Warsaw, IN who currently hails from Kansas City, MO. His passions include Market Research, Brand Development, and Customer Service. Ricardo dreams of starting his own business in the future and hopes to pursue a doctoral education. He would like to thank the entire yearbook staff for making his year as the Marketing Director an absolutely wonderful experience.
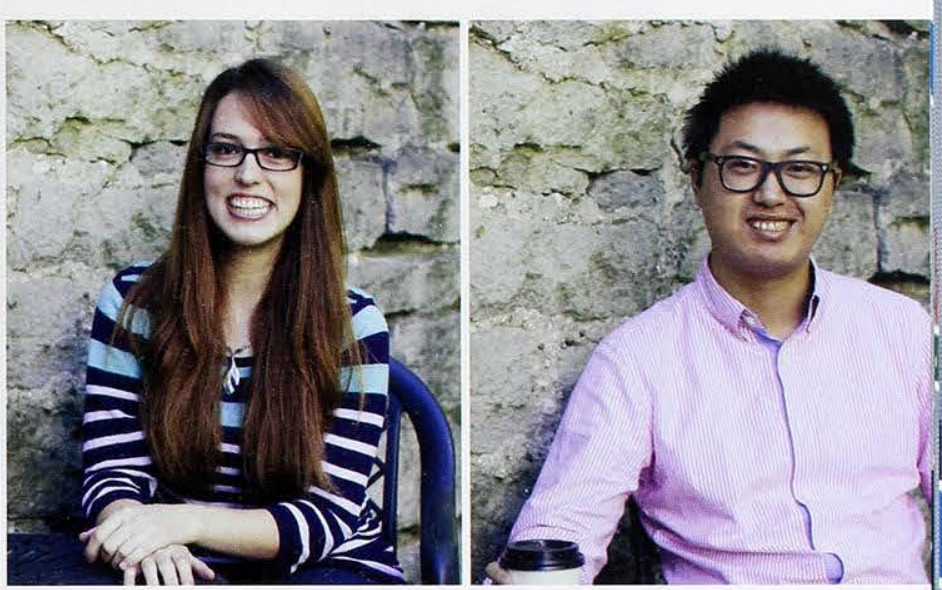

Kyria Luxon

Photographer

Kyria is a photographer from northern Kentucky. She is a sophomore graphic design major and is excited and delighted by all things made of light and color. When she gets her degree. she plans to go to China and start a home for orphaned and abandoned kids, using photography, design, or both to help support herself and the children
Tianle Li

Photographer

Tianle is a sophomore business management major from Hangzhou, China. He loves traveling and capturing the beauty of the world through his camera. He enjoys working as yearbook photographer and serving our community in his position.

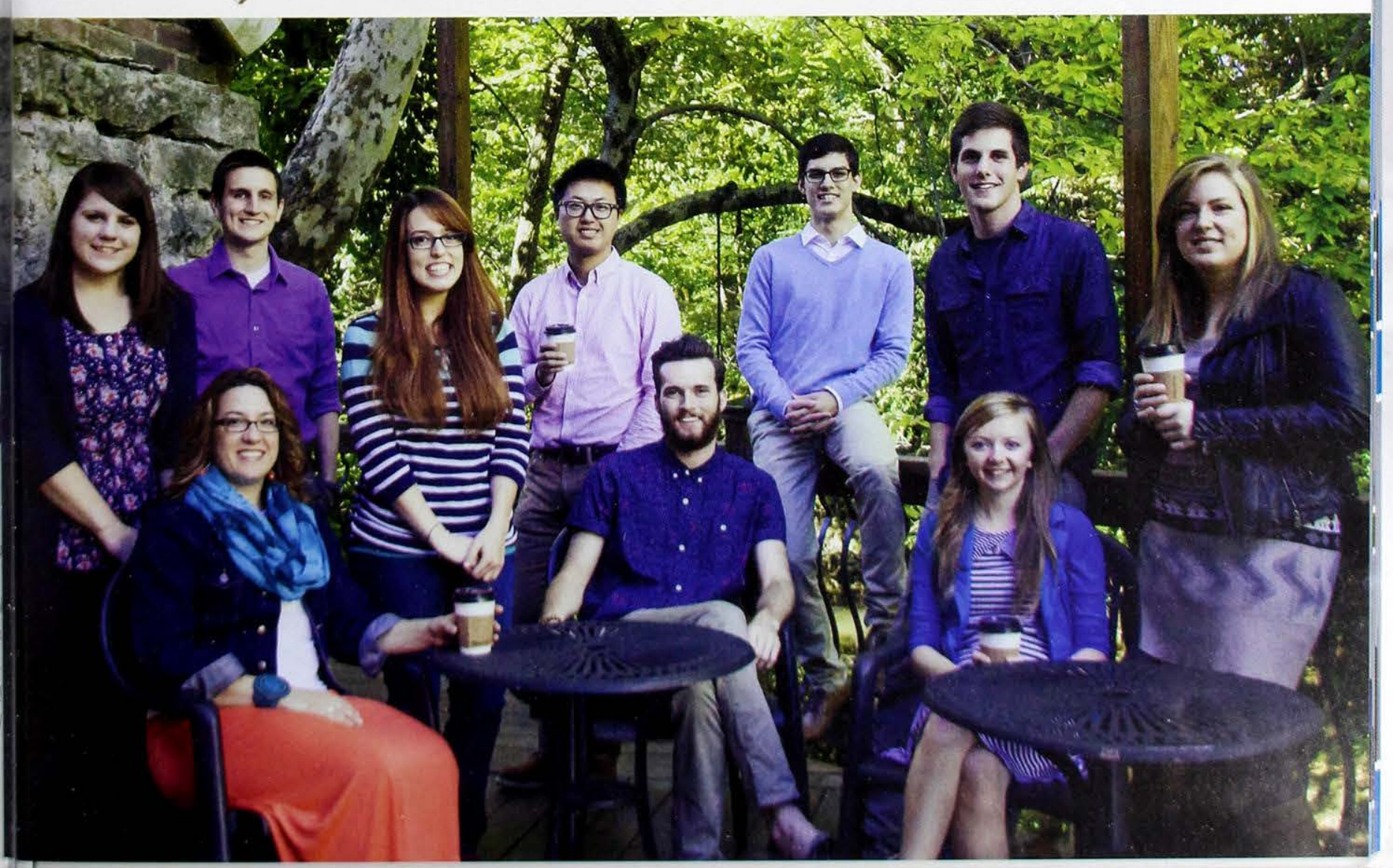




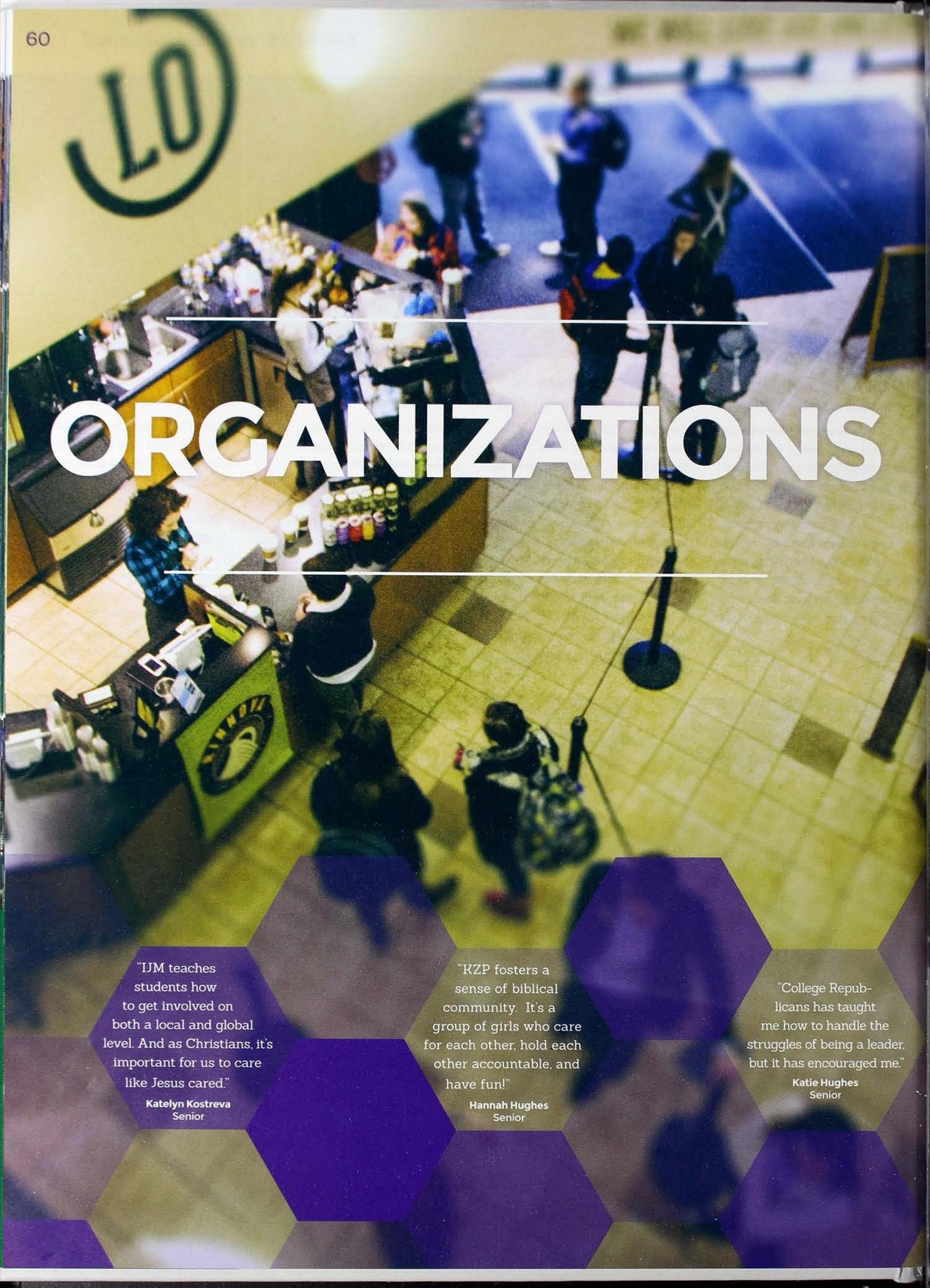


Pas

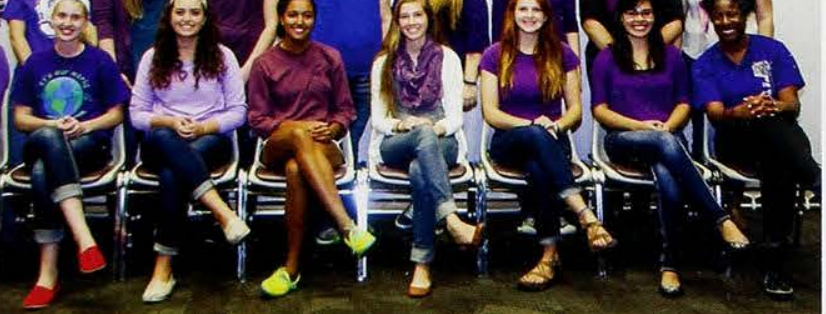

EPSILON ALPHA PI I Social work org serving the community \& building relationships

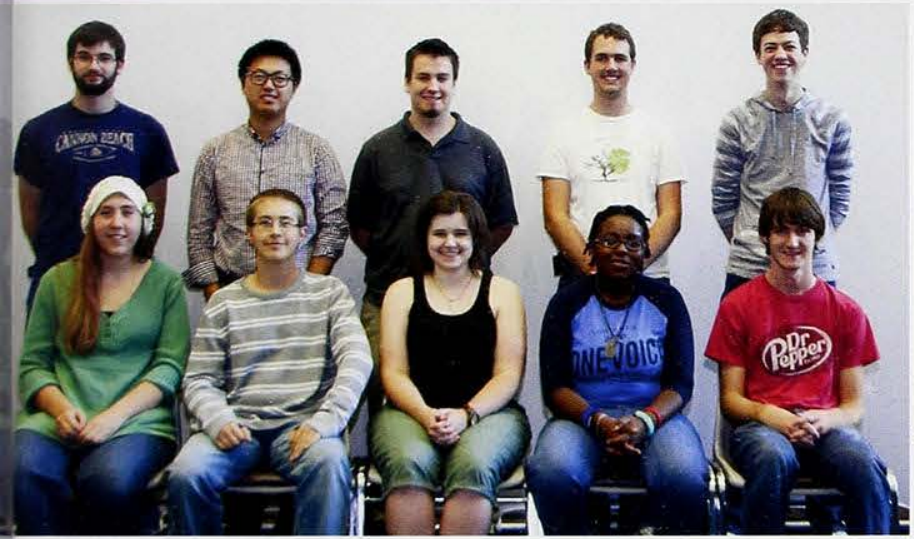

FILMGATE MEDIA I Dedicated to helping students through the creation of media

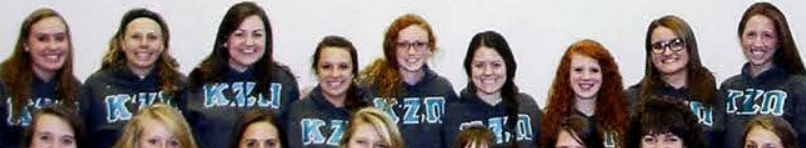
129.100 c.

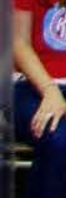

\section{?}

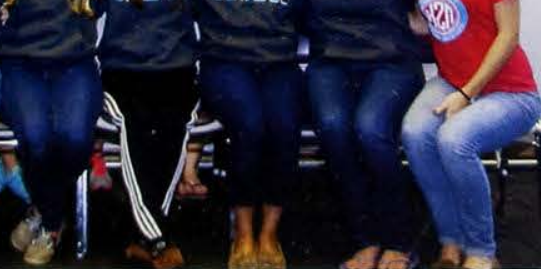

KAPPA ZETA PI | Women's social and fellowship org

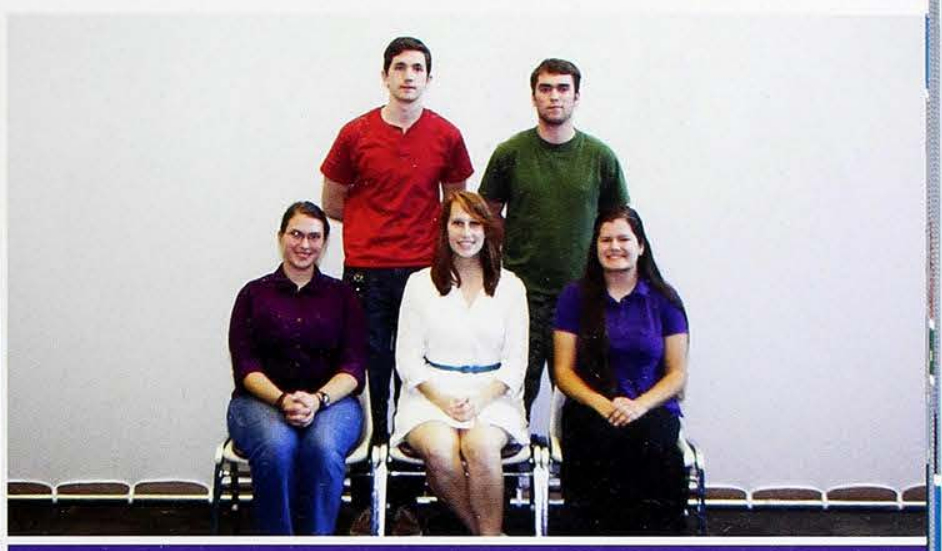

EPSILON PI LAMBDA | History and Government org
MU KAPPA / Cedarville's chapter of the national organization to unite missionary kids

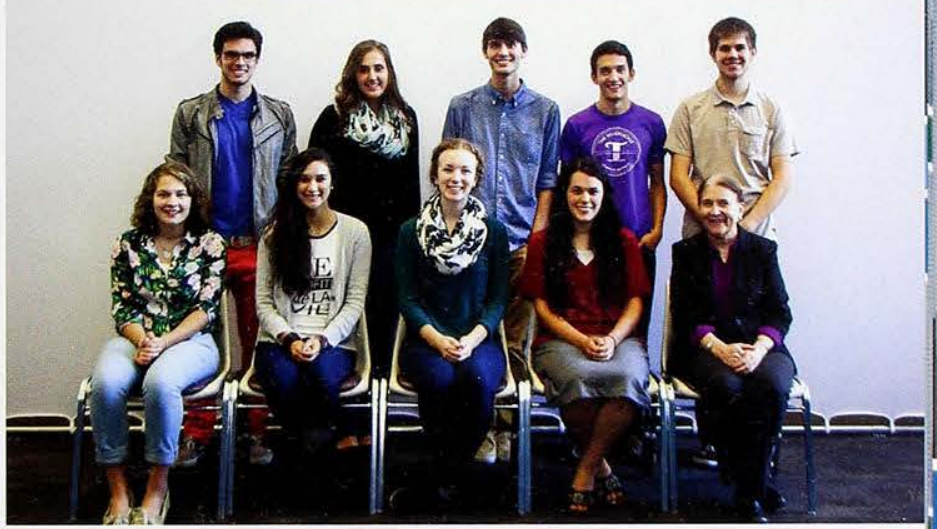

FRENCH CLUB | Promoting knowledge of French language and culture on campus

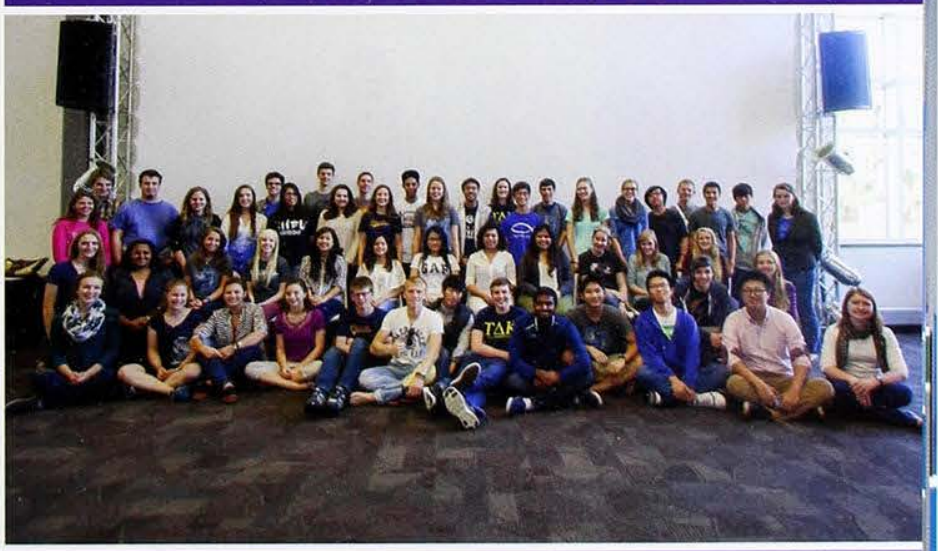

MU KAPPA I Cedarvilles chapter of the national organization to unite missionary kids
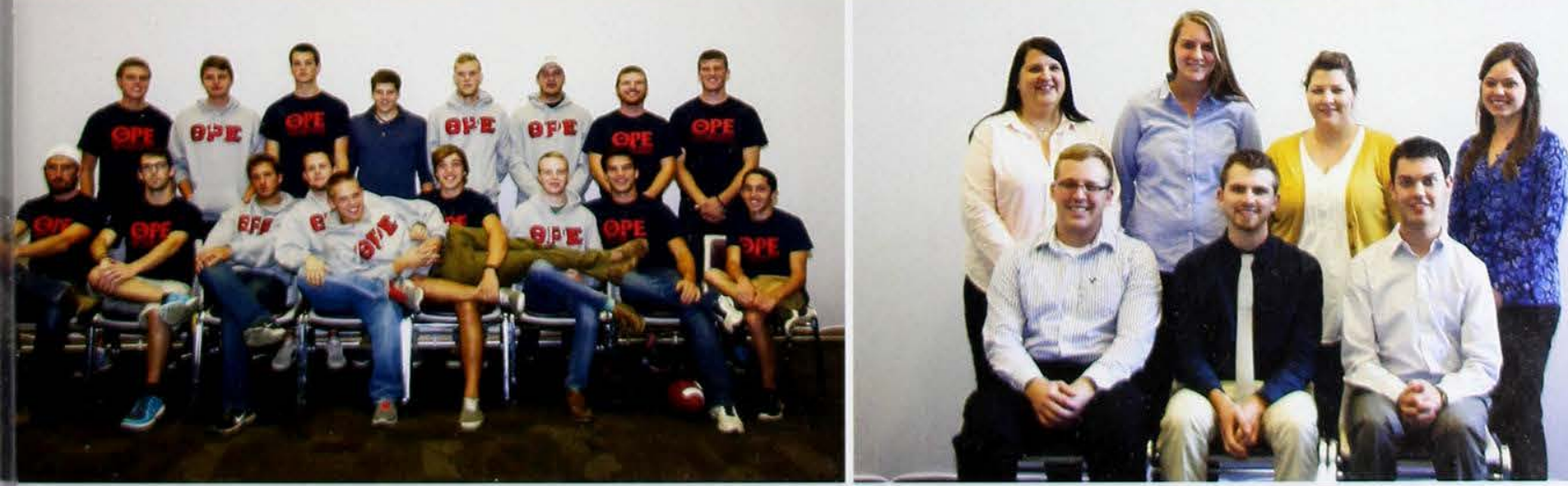


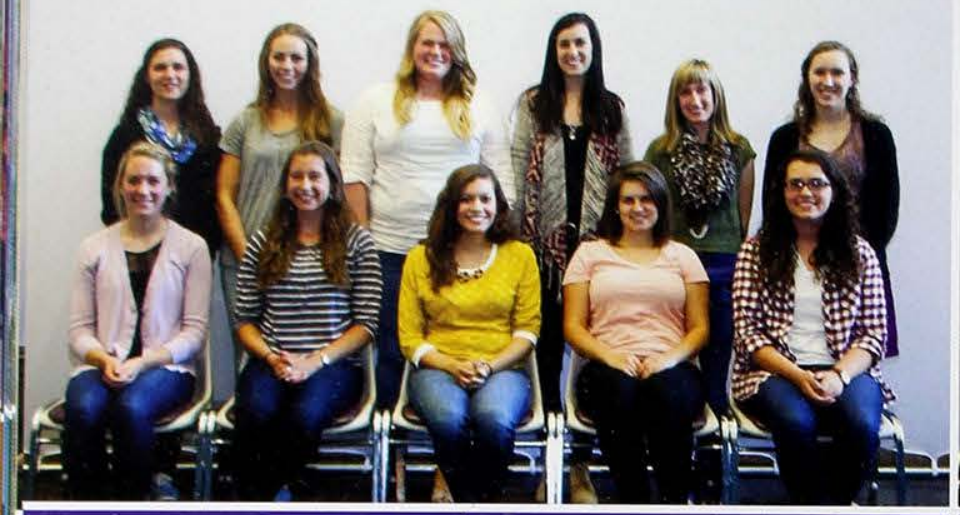

PHI ALPHA | Social Work Honors Society

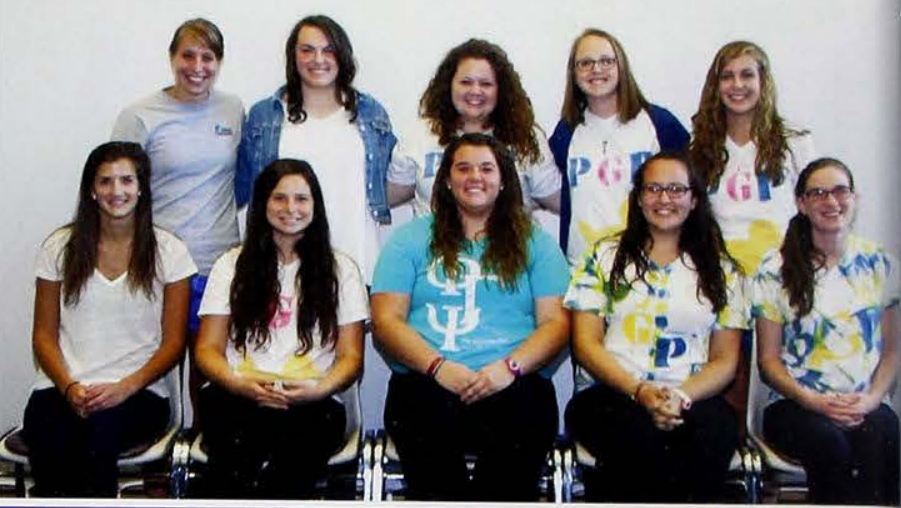

PHI GAMMA PSI I Women's social and fellowship org

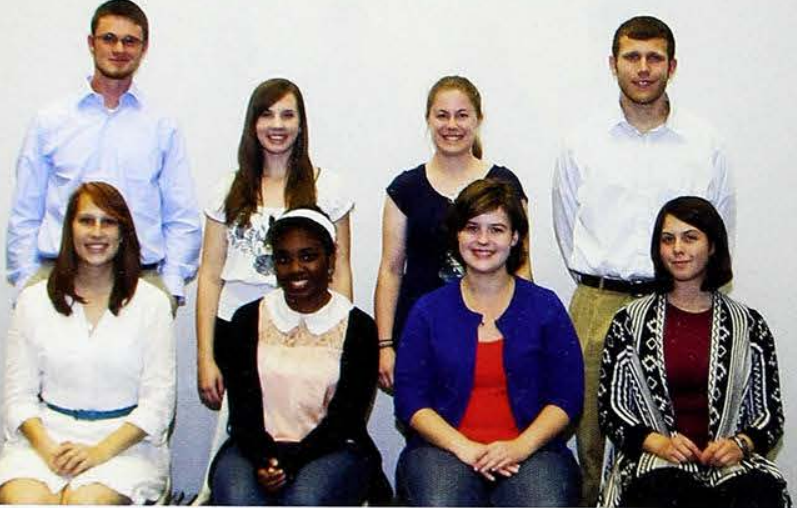

SAAB | Student Academic Advisory Board
(8) $\int^{2}$ a

$1-N \times 1-1+1$

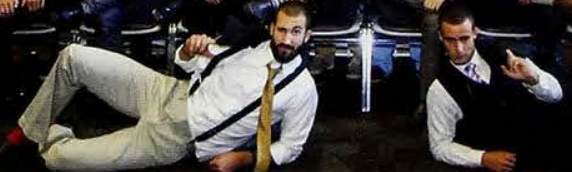

SIGMA PHI LAMBDA | Christ-centered brotherhood, honoring God and loving others

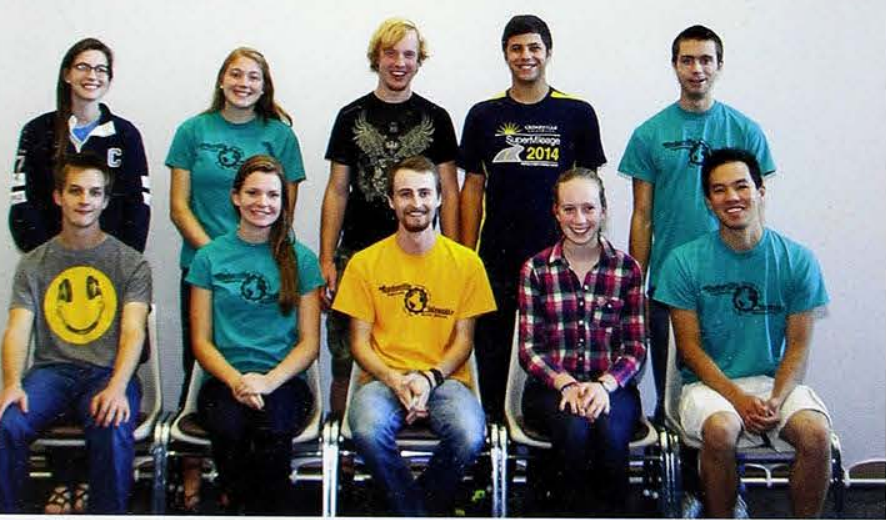

SEAM | Society of Engineers Aiding Missions

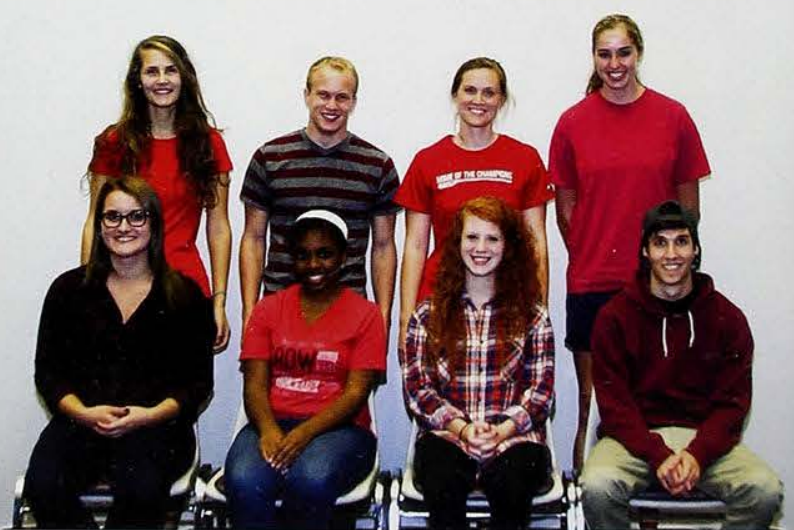

SPW I Society of Professional Writing
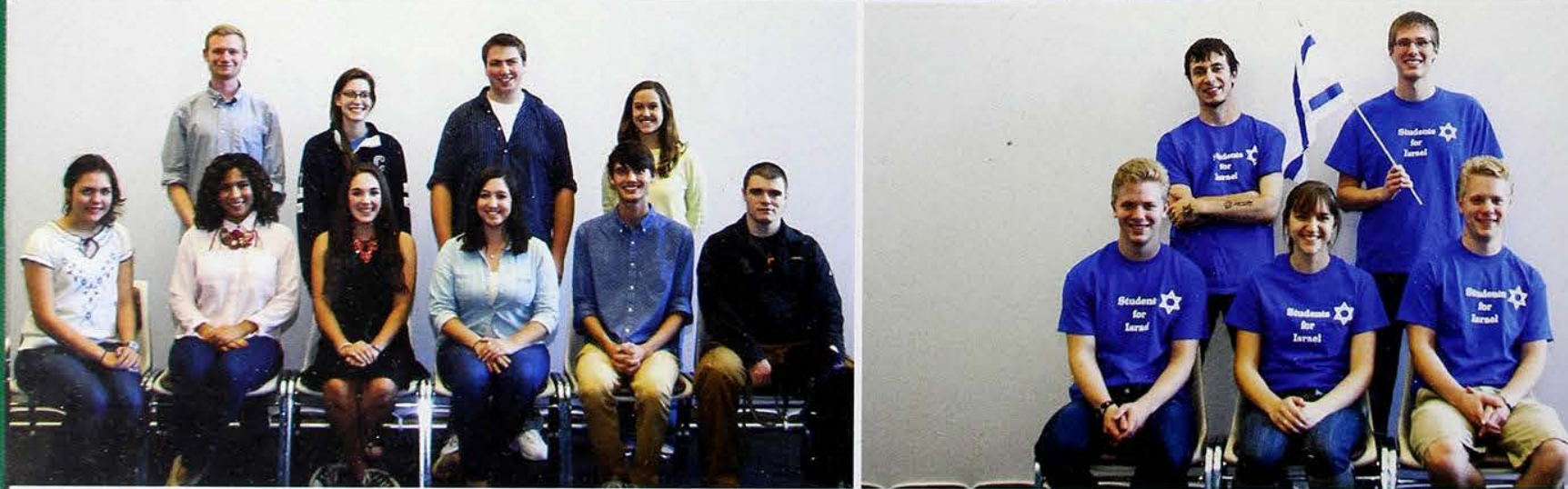



\section{CHAIRS AND DEANS}

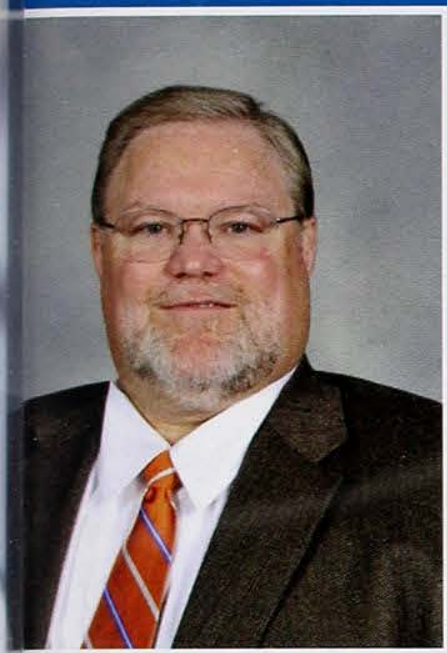

Douglas Anderson Chair of Pharmacy Practice

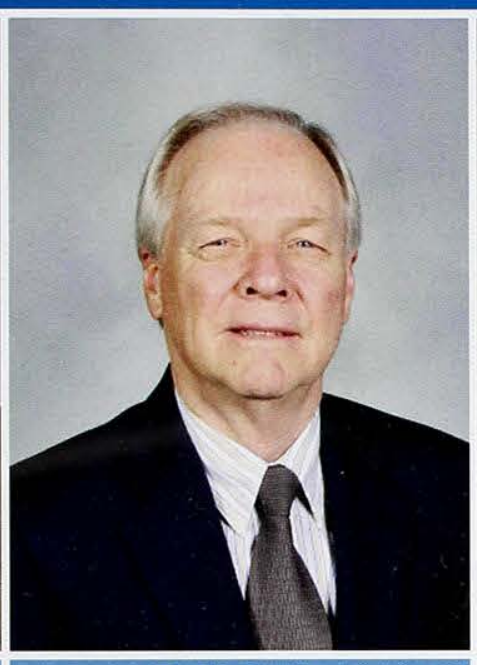

Lynn Brock

Dean of Library Services

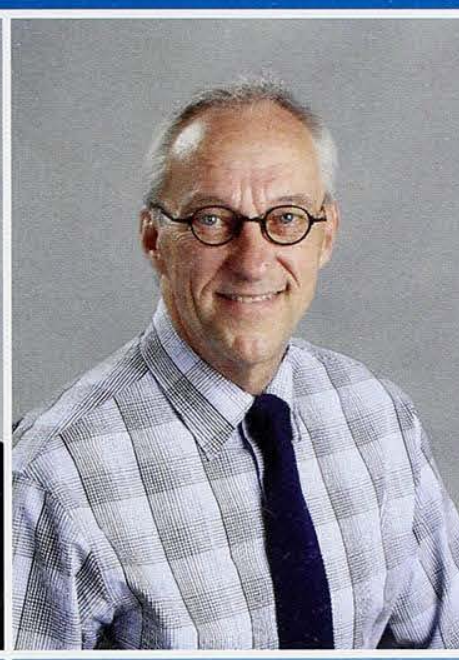

Terry Chamberlain Chair of Art. Design, and Theatre

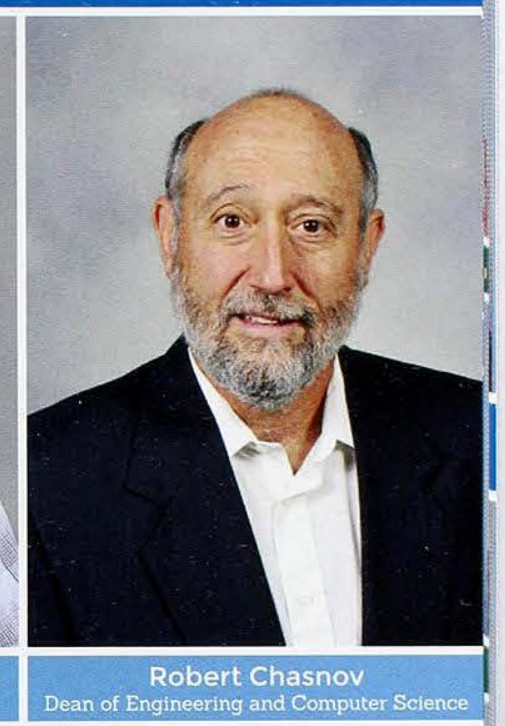

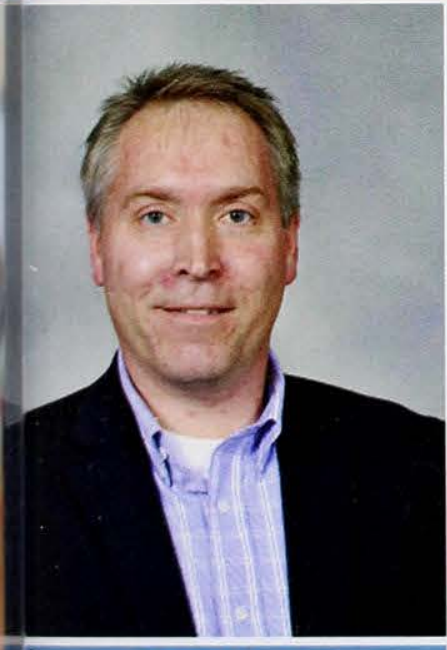

Jeremy Ervin Dean of Education

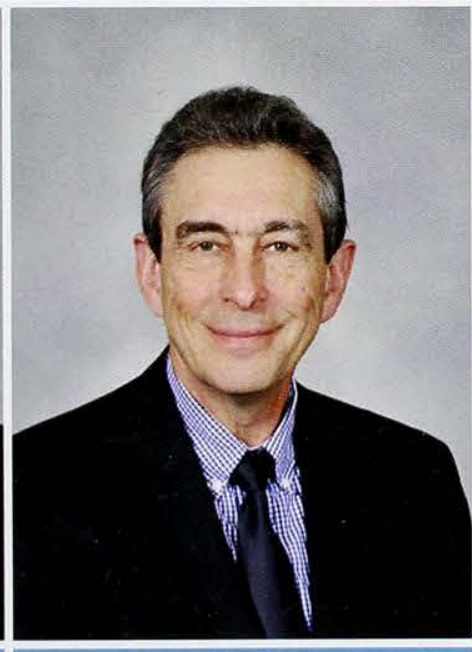

Dennis Flentge Chair of Science and Mathematics
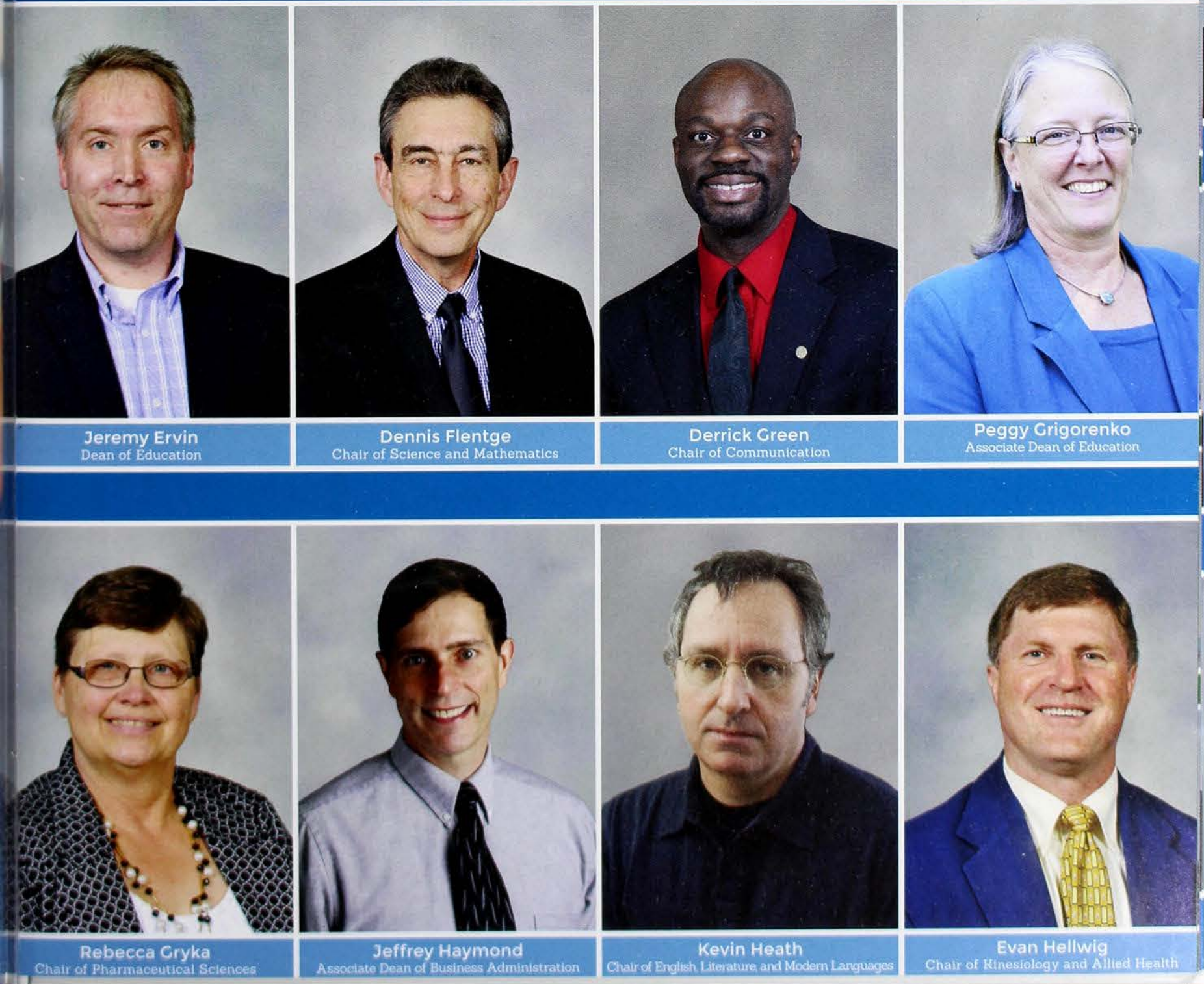
68 | FACULTY AND STAFF

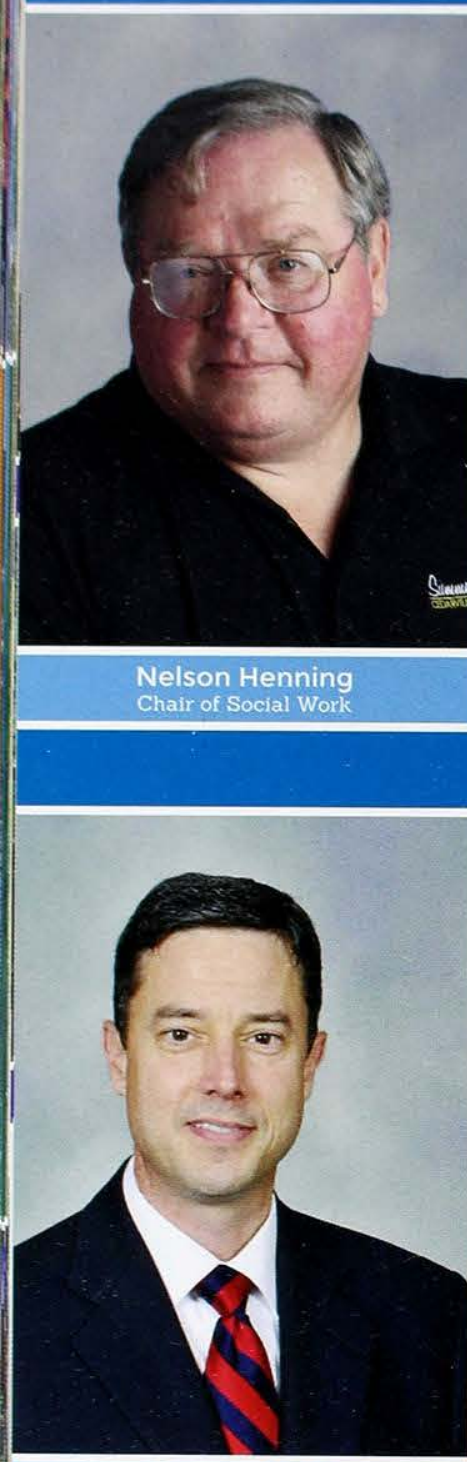

Thomas Mach

Chair of History and Government

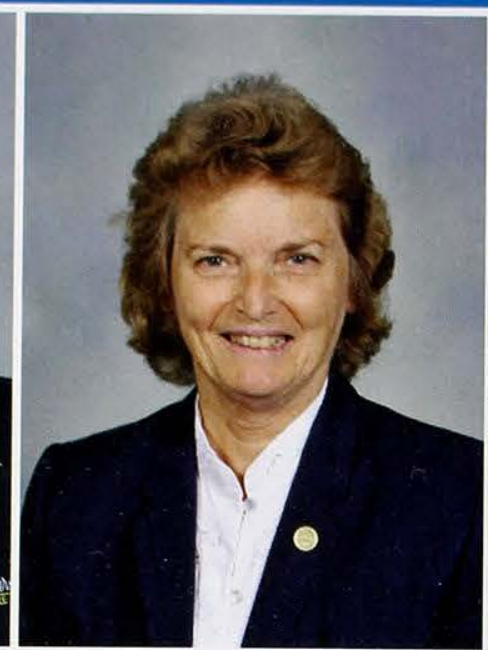

Pamela Johnson Dean of Undergraduate Studies

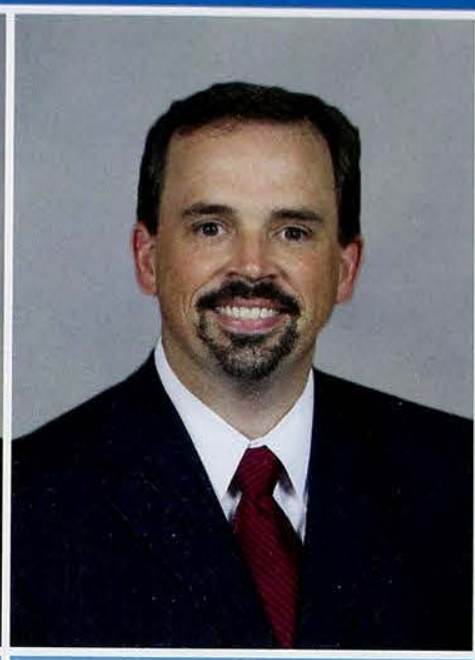

Jason Lee Dean of Biblical and Theological Studies

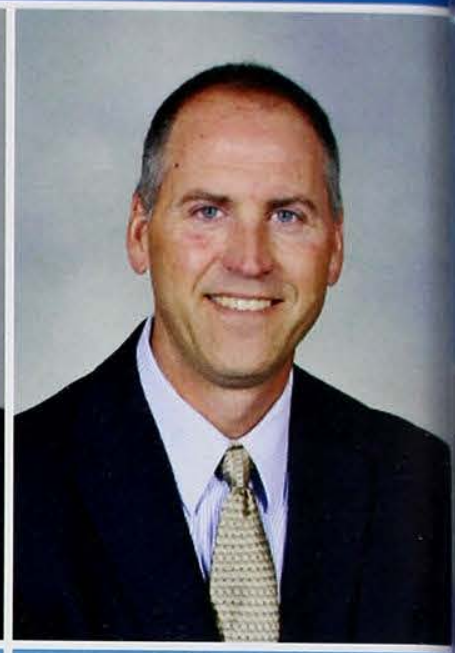

Jeffrey Lewis Associate Dean of Pharmacy Practice

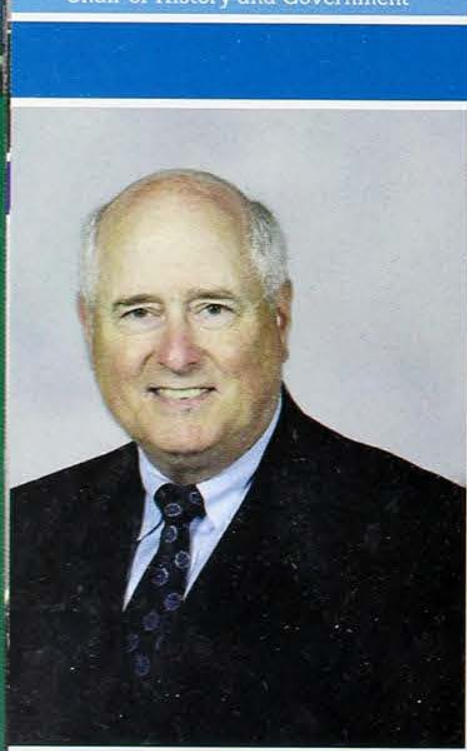

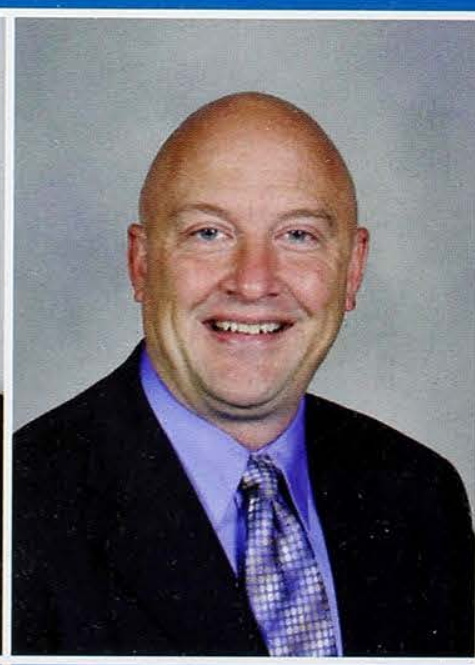

Marc Sweeney Dean of Pharmacy

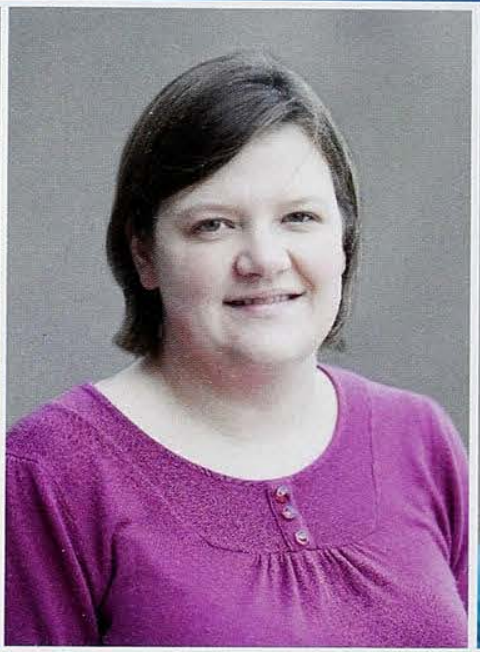

Angelia Mickle Interim Dean of Nursing

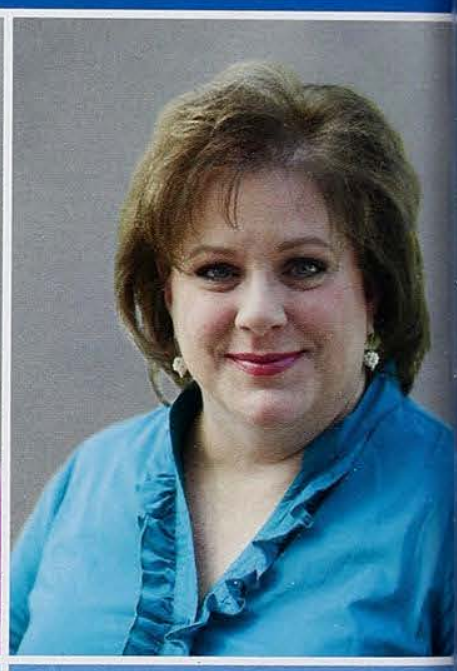

Beth Porter Chair of Music and Worship
ASSISTANT DEANS Randall McKinion Daniel Sterkenburg Stephen Gruber Samuel SanGregory Randall Johnson Amy Voris

Ginger Cameron 

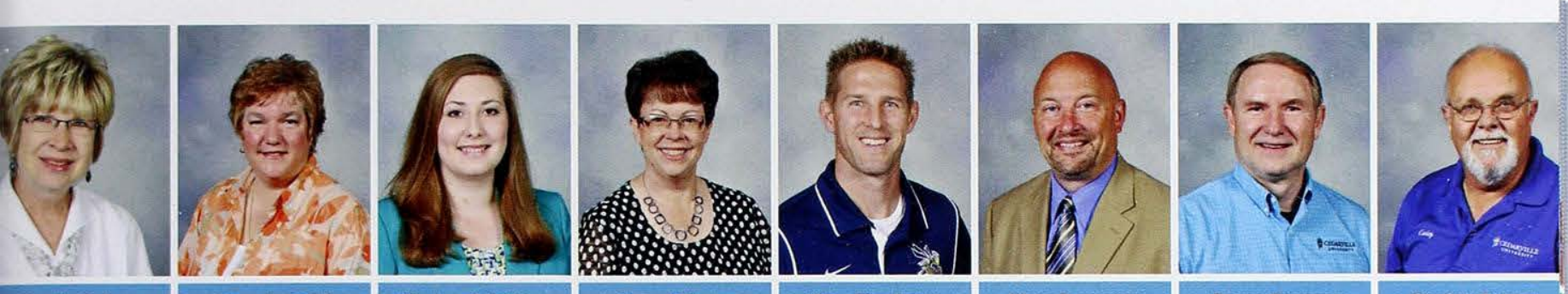

Jackie Pyles Brenda Reid

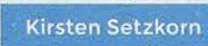

.

Wes Stephens Marc Sweeney

Bruce Traeger

Cooley Turner

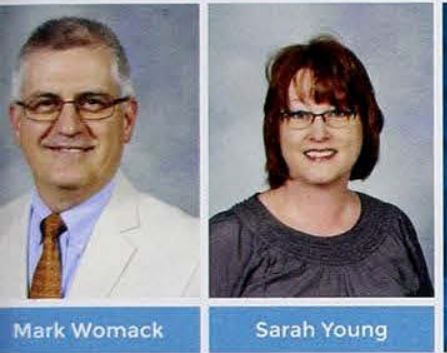

"Do you know what I remember about being a student?-We wore skirts all the way to the ground -so we could hide-pants under them!"

\section{Luann Nicholas}

Library ILL Services

Sarah Young

ADMINISTRATIVE COUNCIL

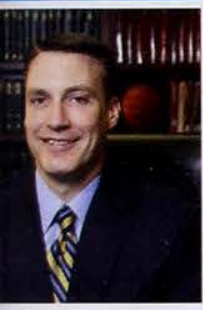

Thomas White President
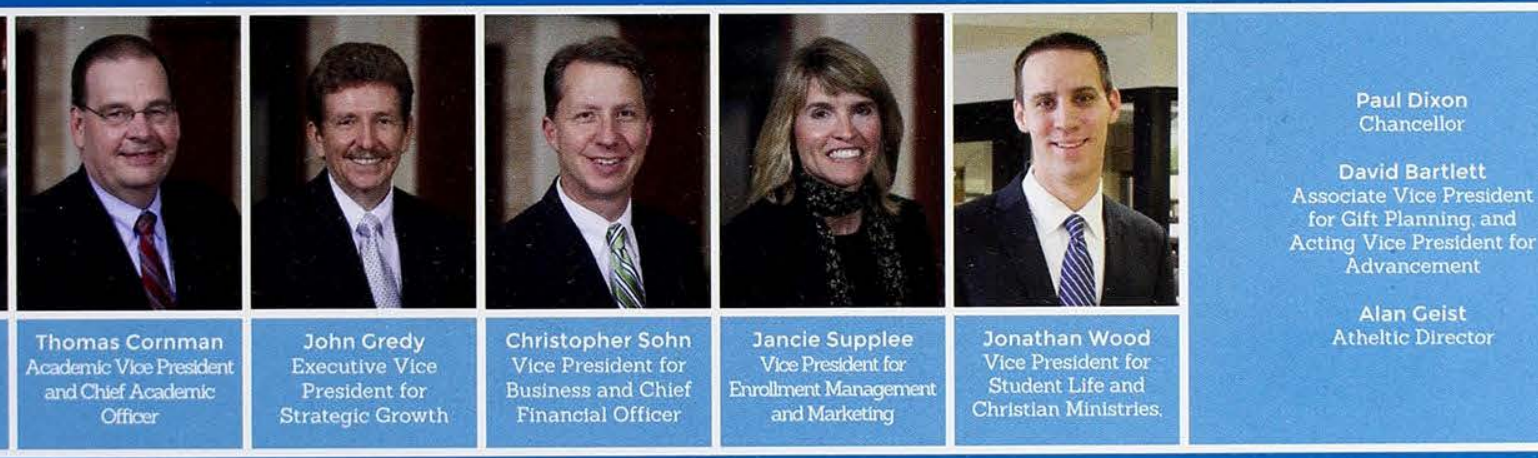

TRUSTEES

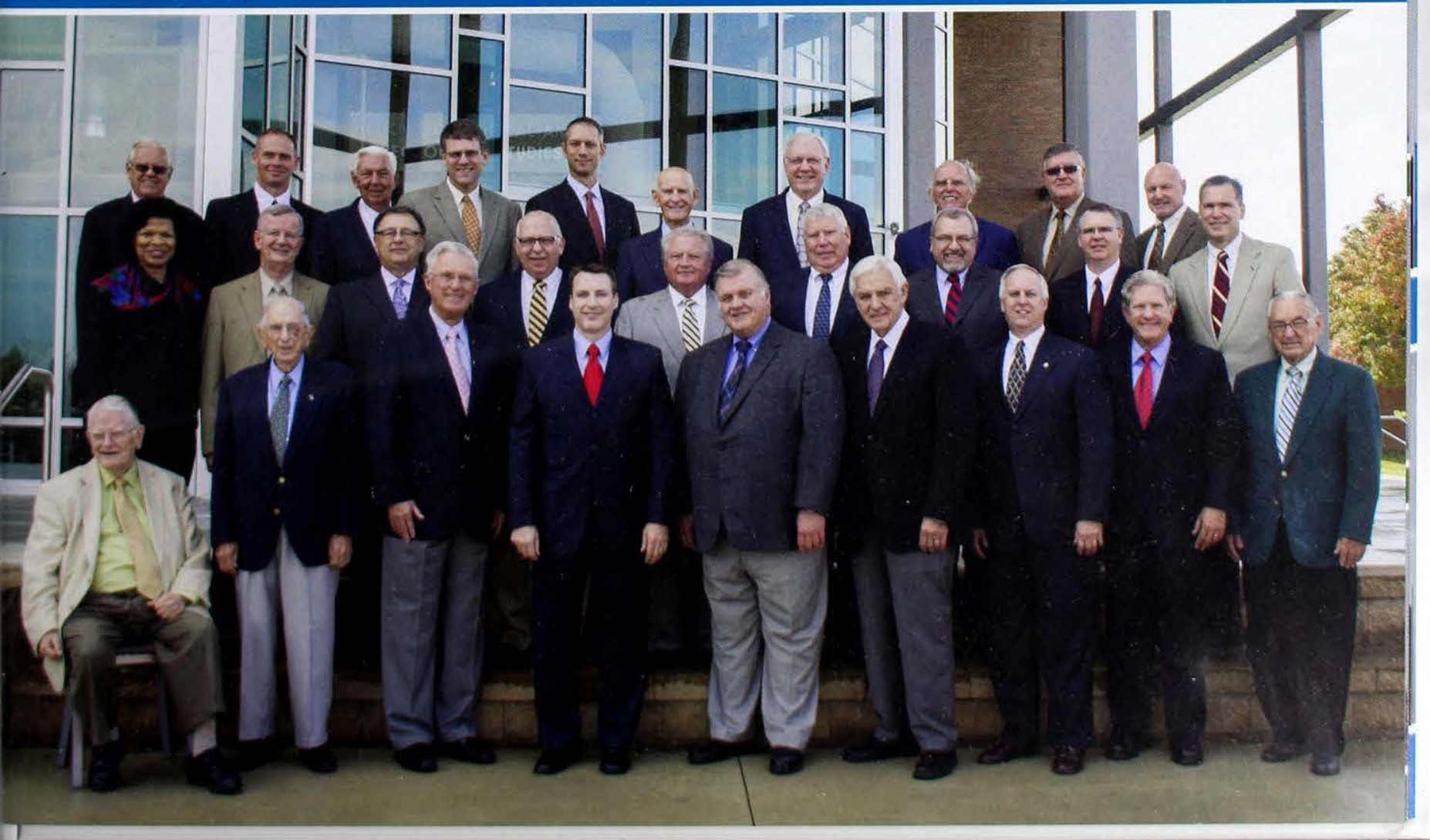




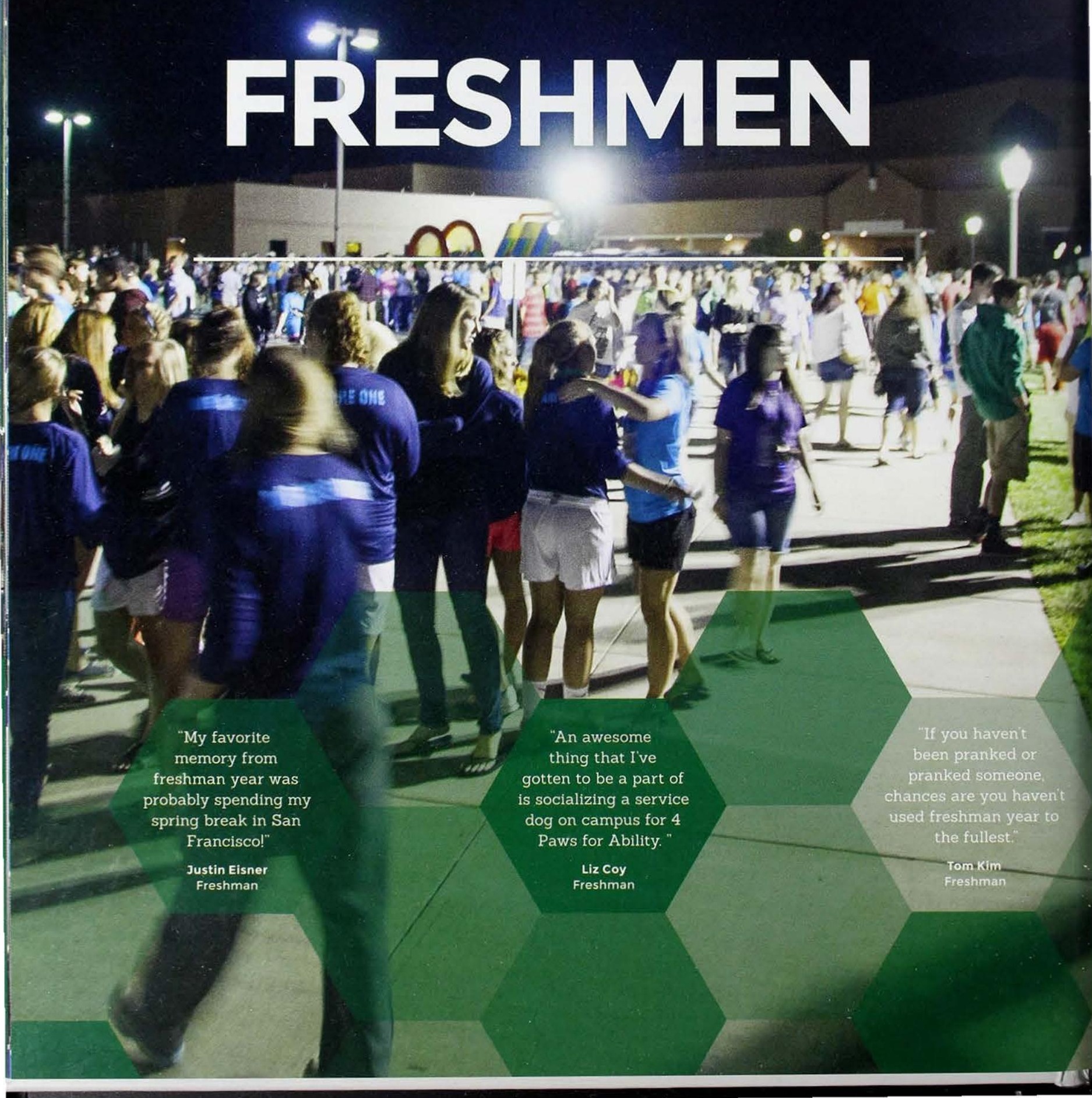




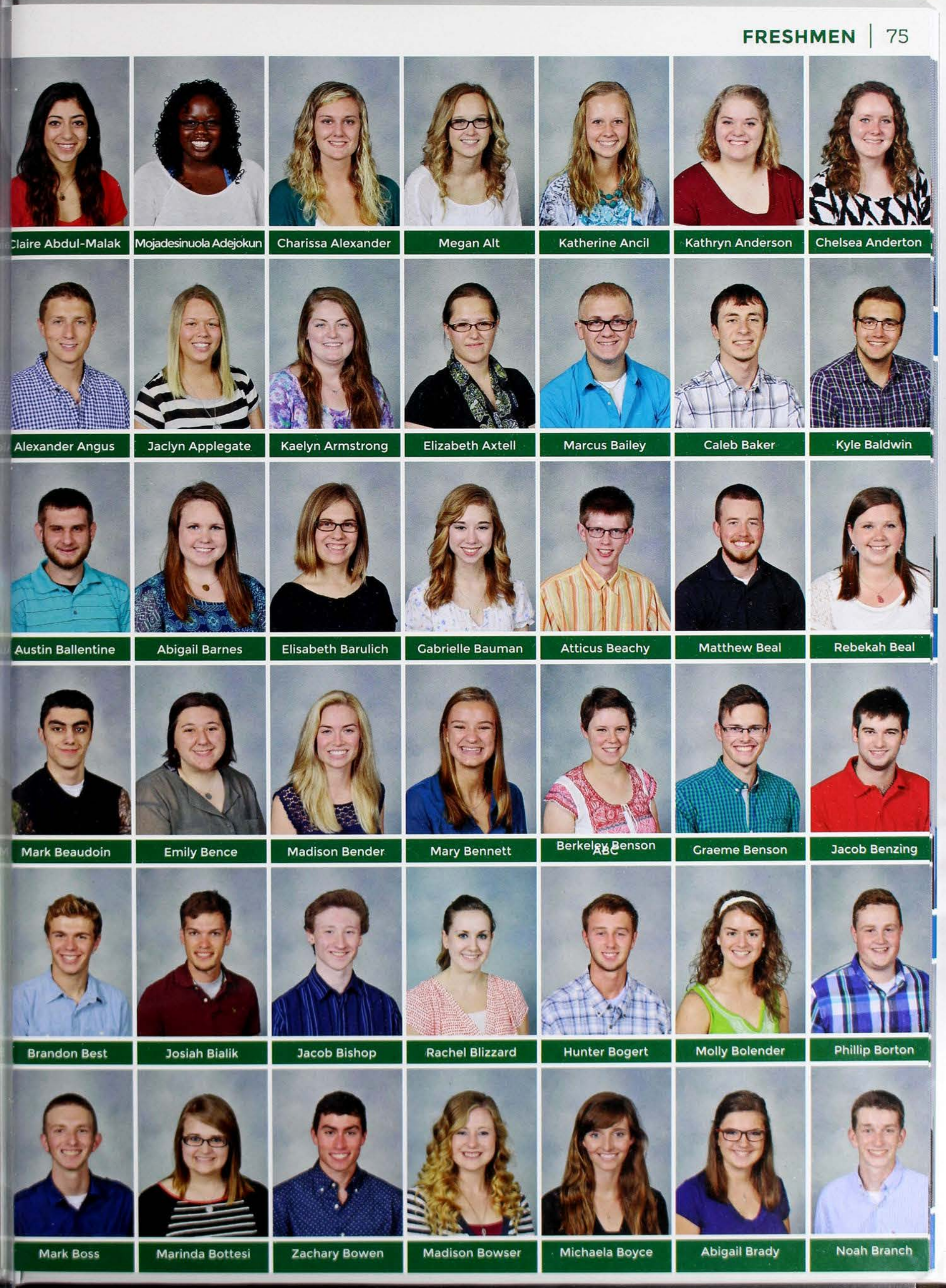


76 | FRESHMEN

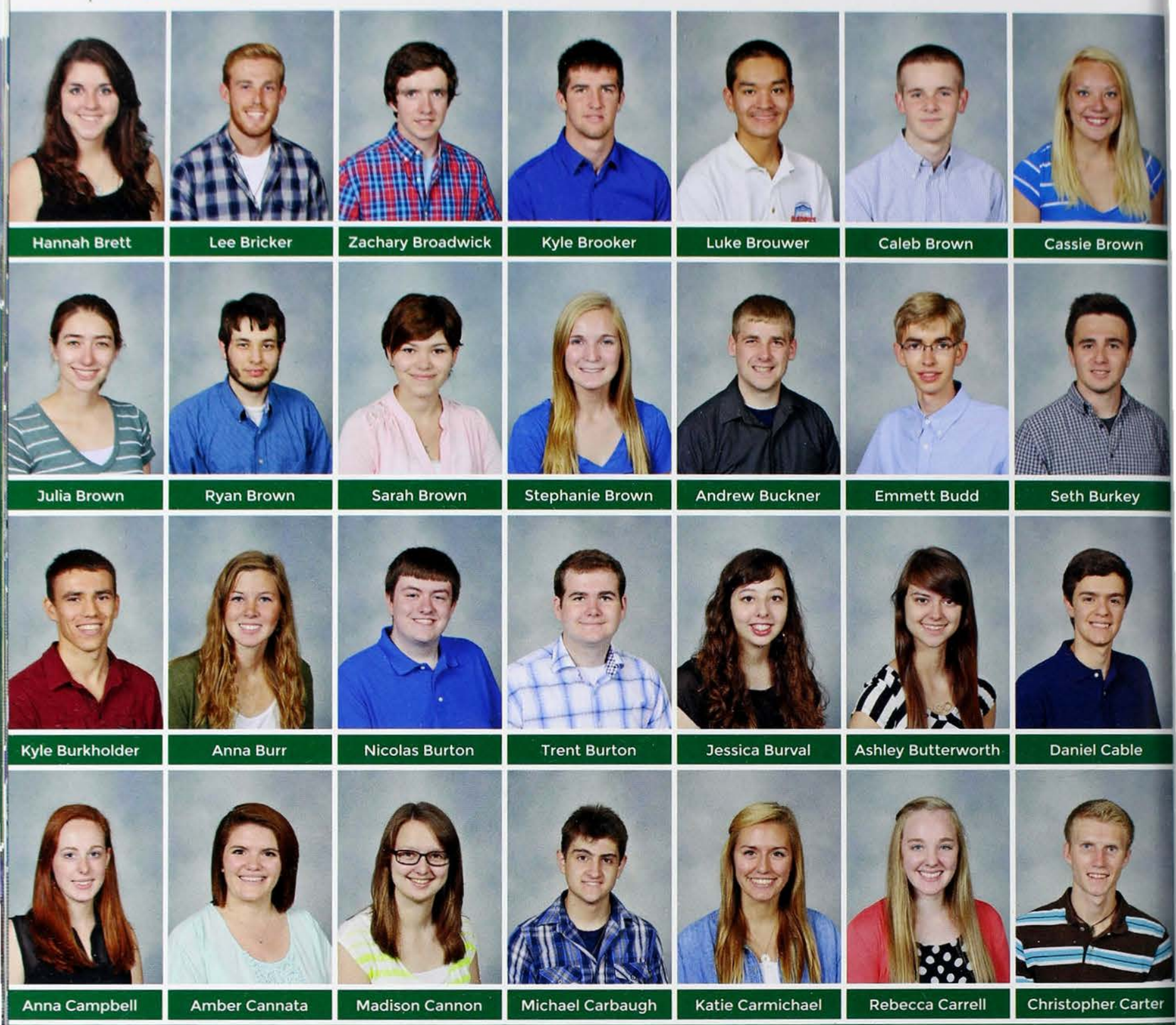

"For me, being a freshman has been about discovering who God created me to be. All of the little life things like eating in Chuck's with friends, worshiping together in chapel, meeting people in class, laughing at DTR shows, or studying in the HSC have worked together to shape the person I am becoming. I couldn't be more grateful."

Amy Searl, Freshman 




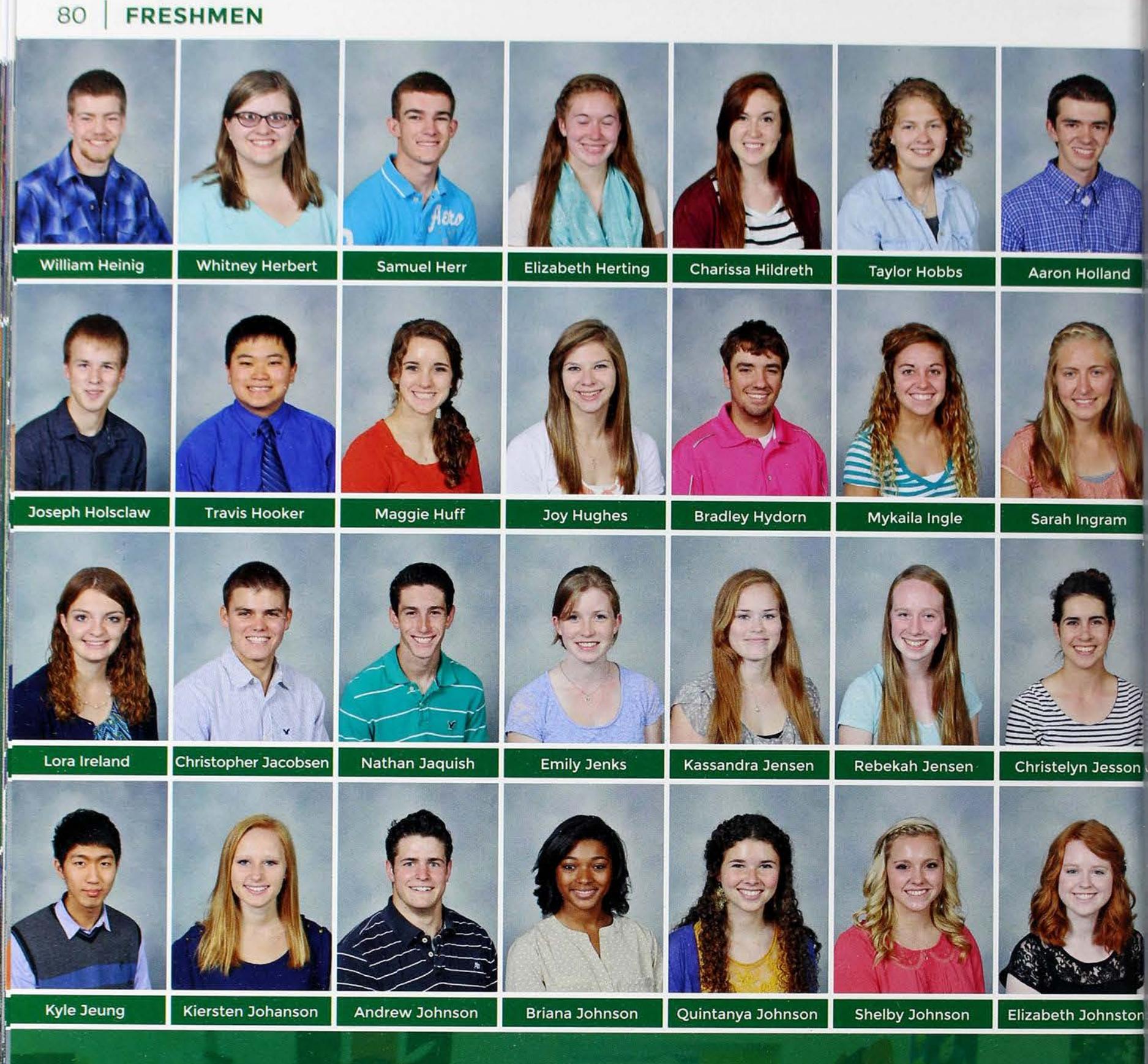



82 FRESHMEN

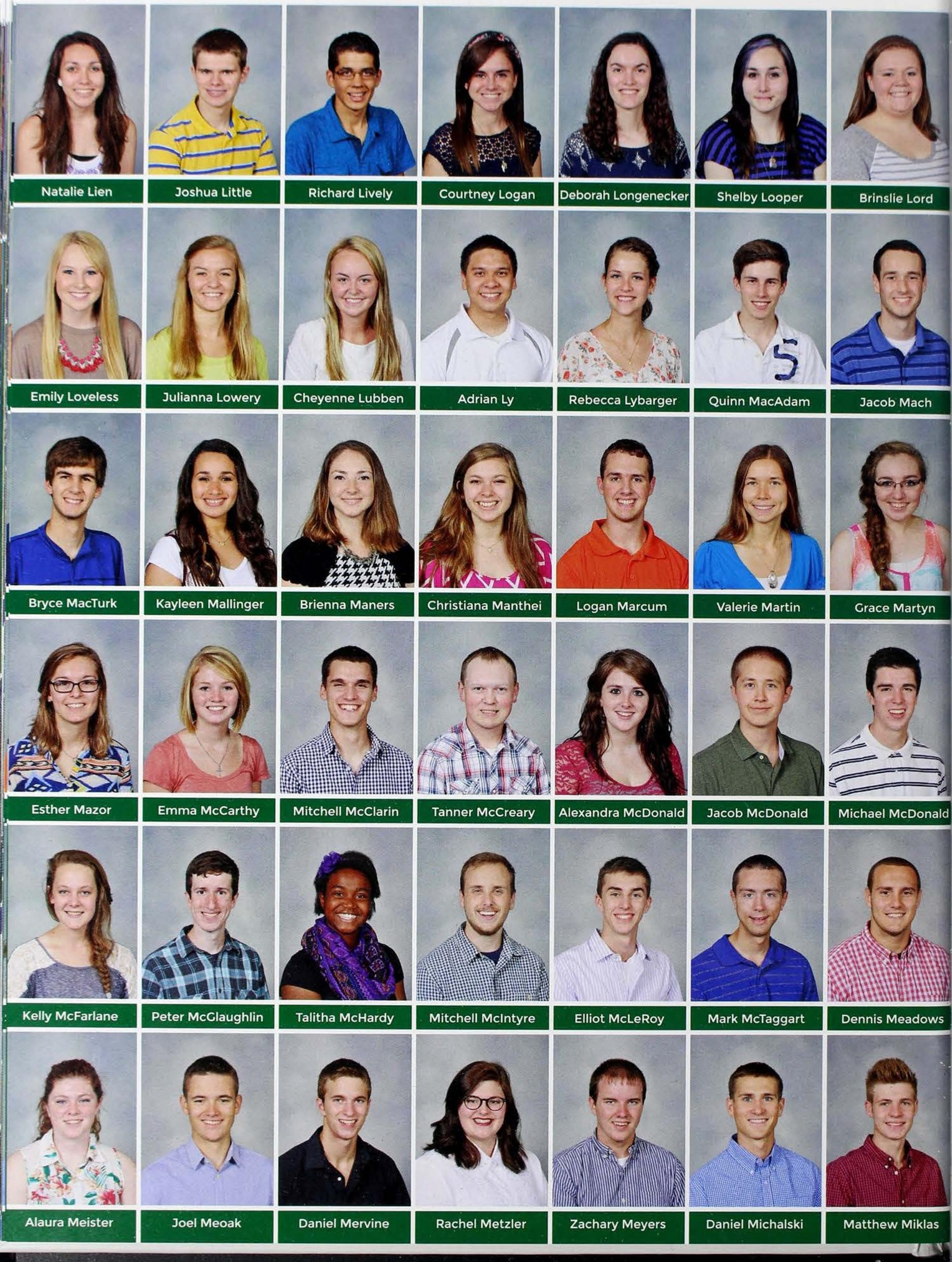






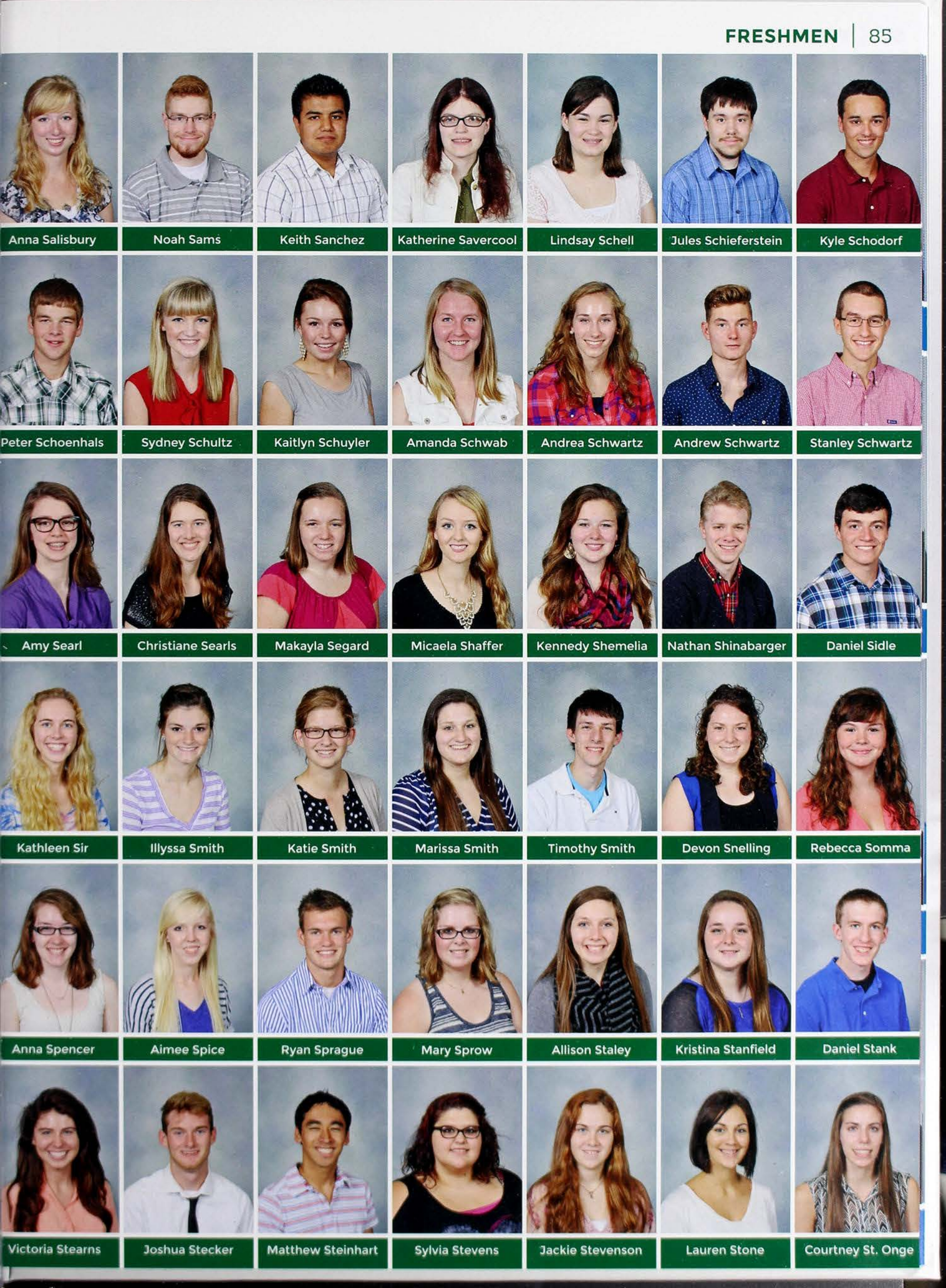




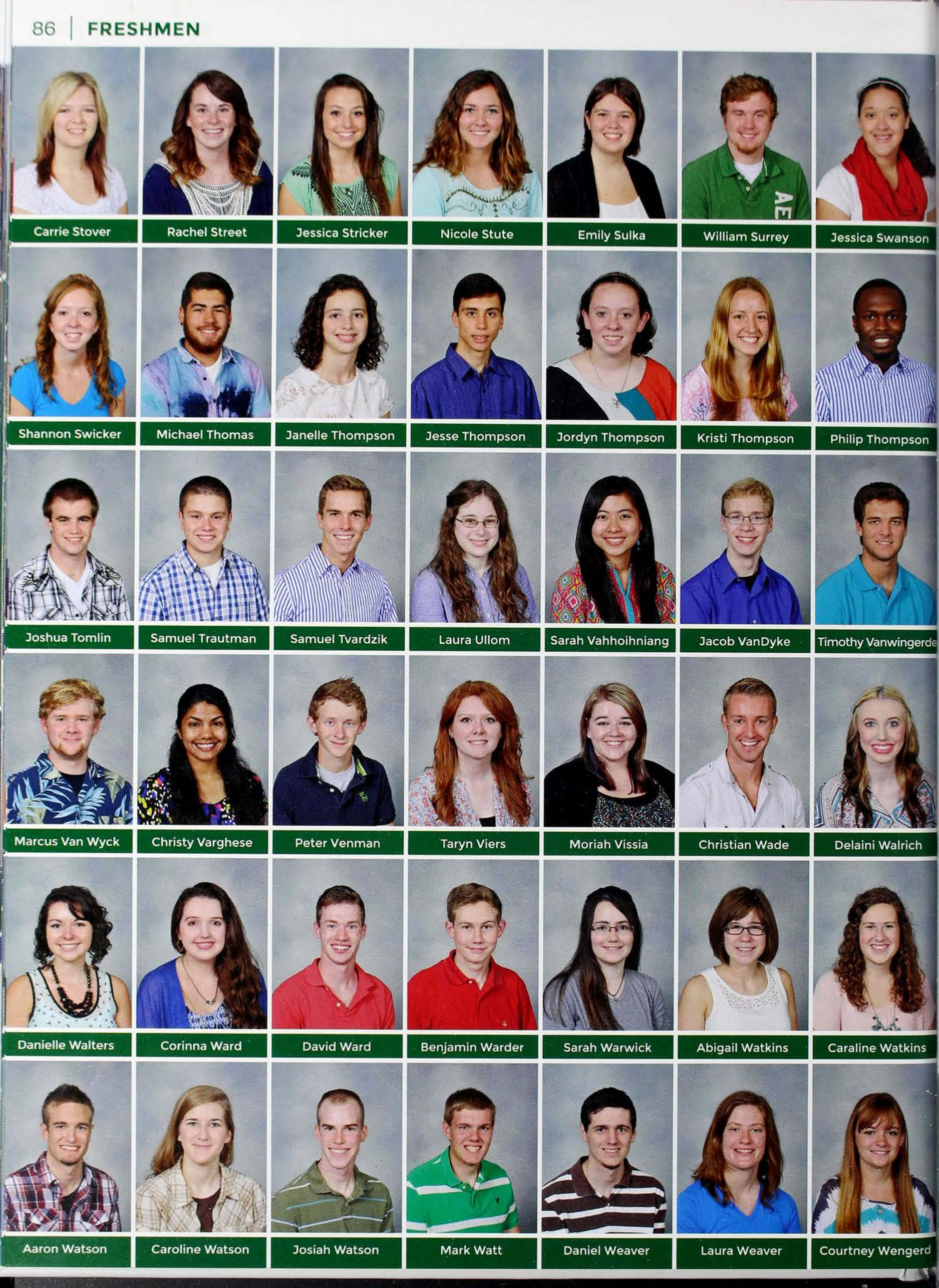




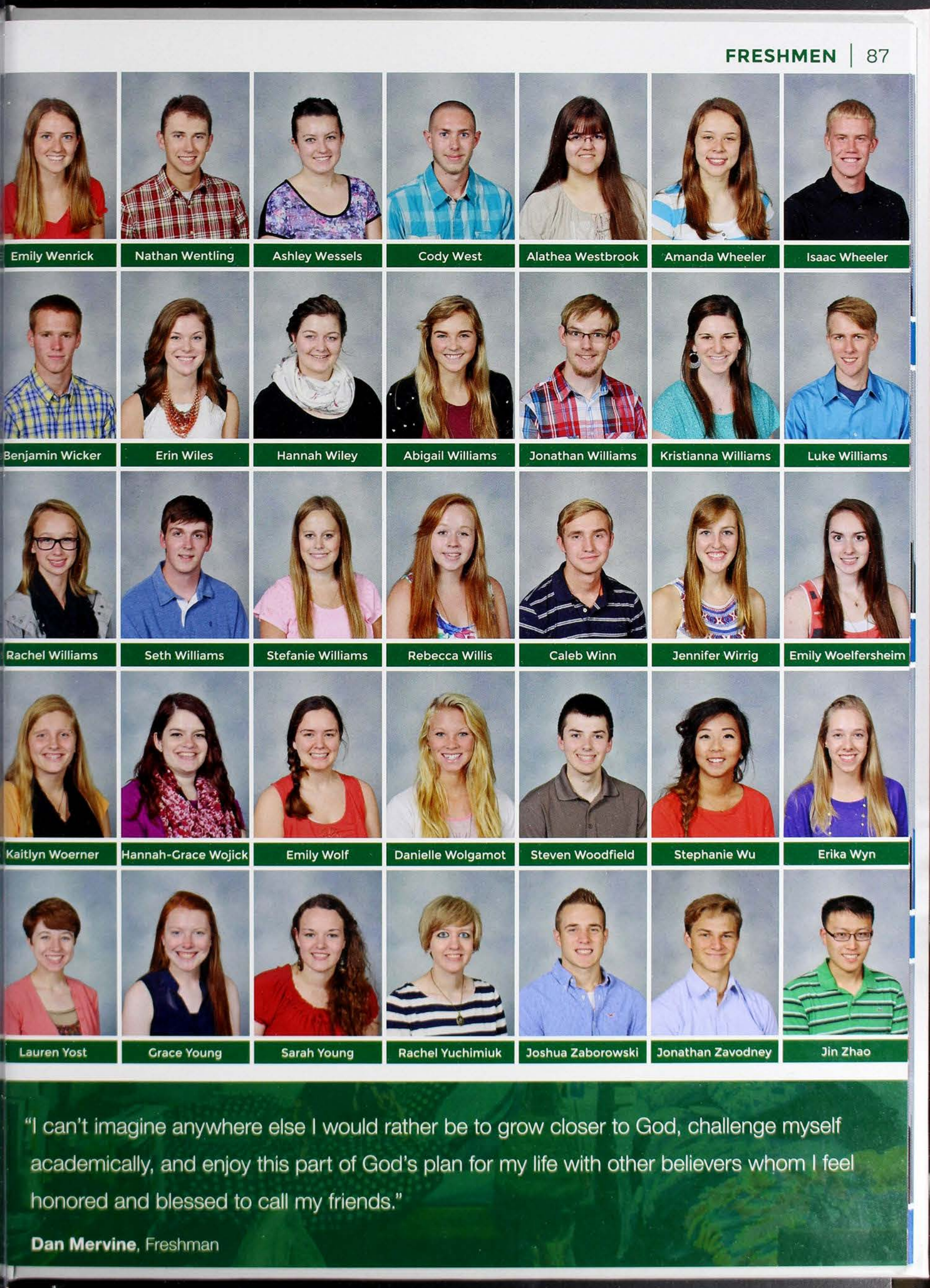



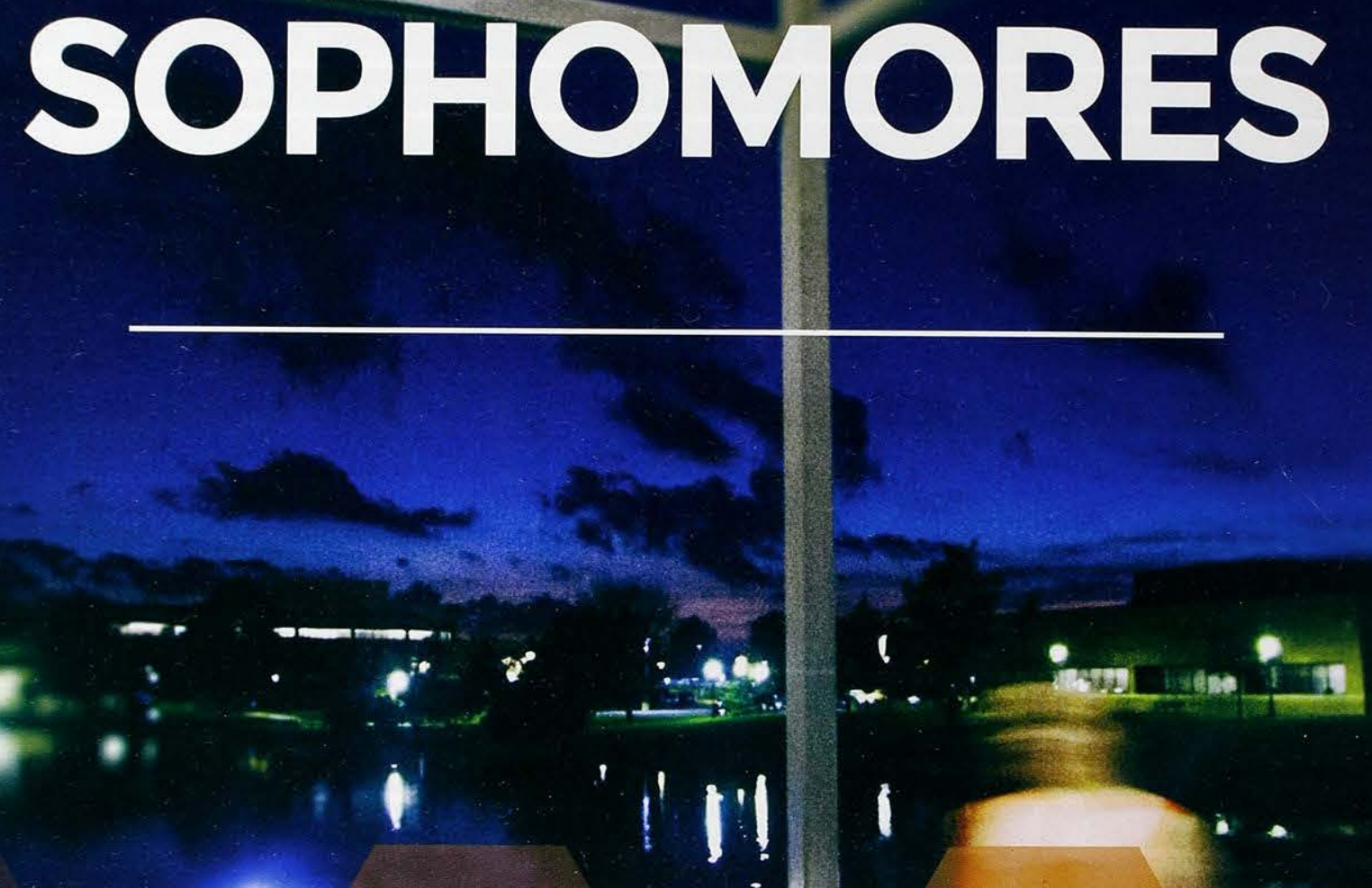


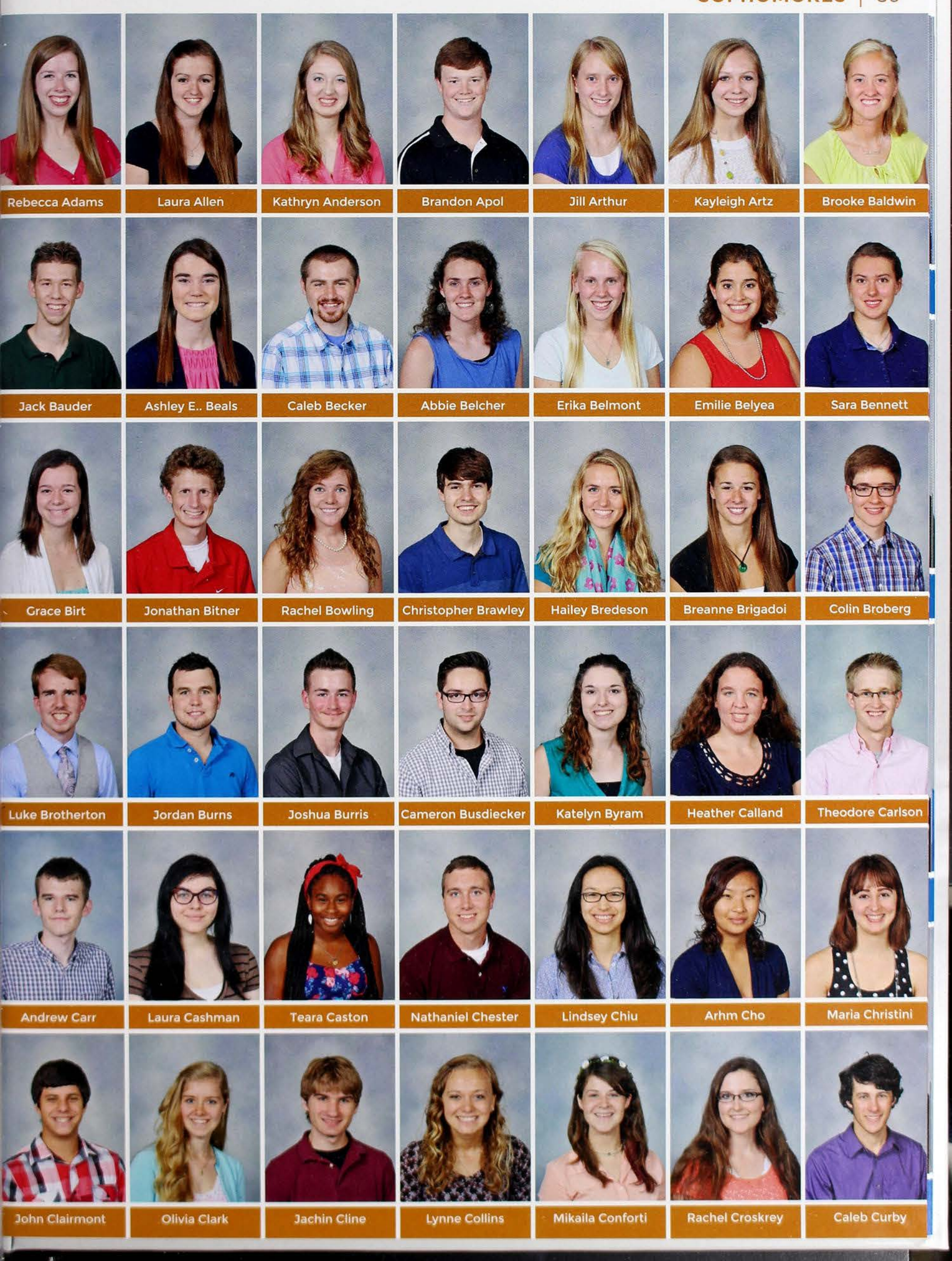




$$
\begin{aligned}
& \text { RBOPORO } \\
& \text { PRABR? }
\end{aligned}
$$

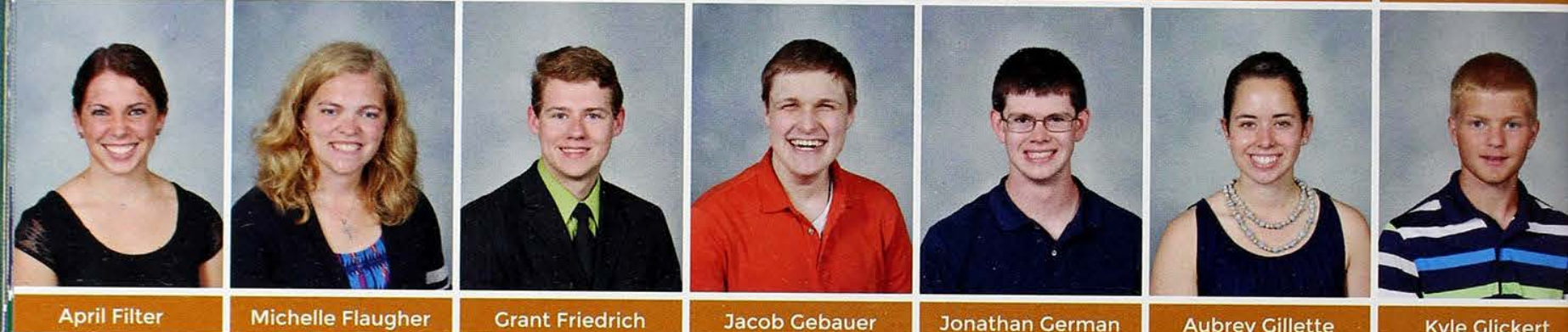

$$
\begin{aligned}
& \text { o } 8 \text { an }
\end{aligned}
$$




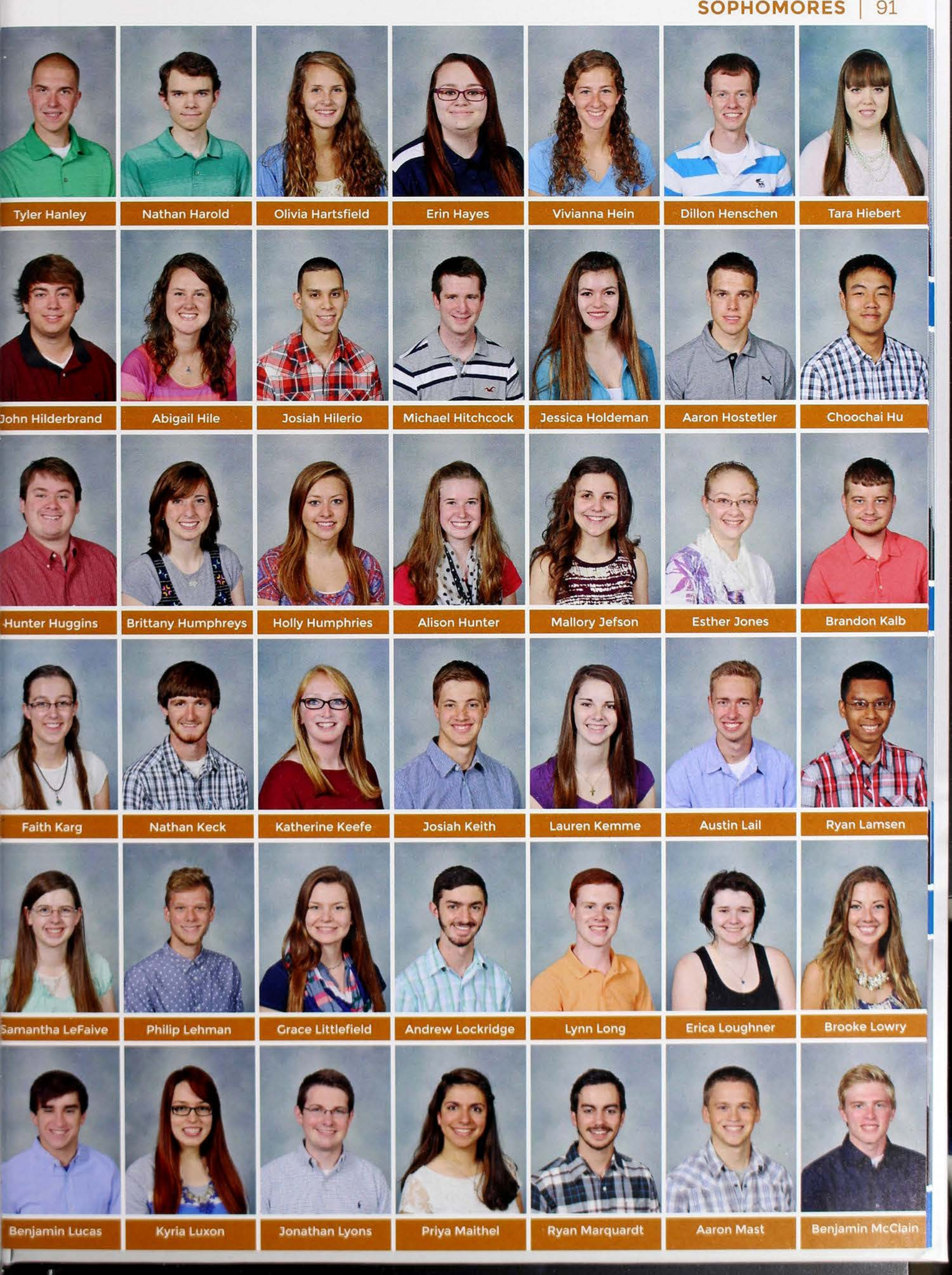





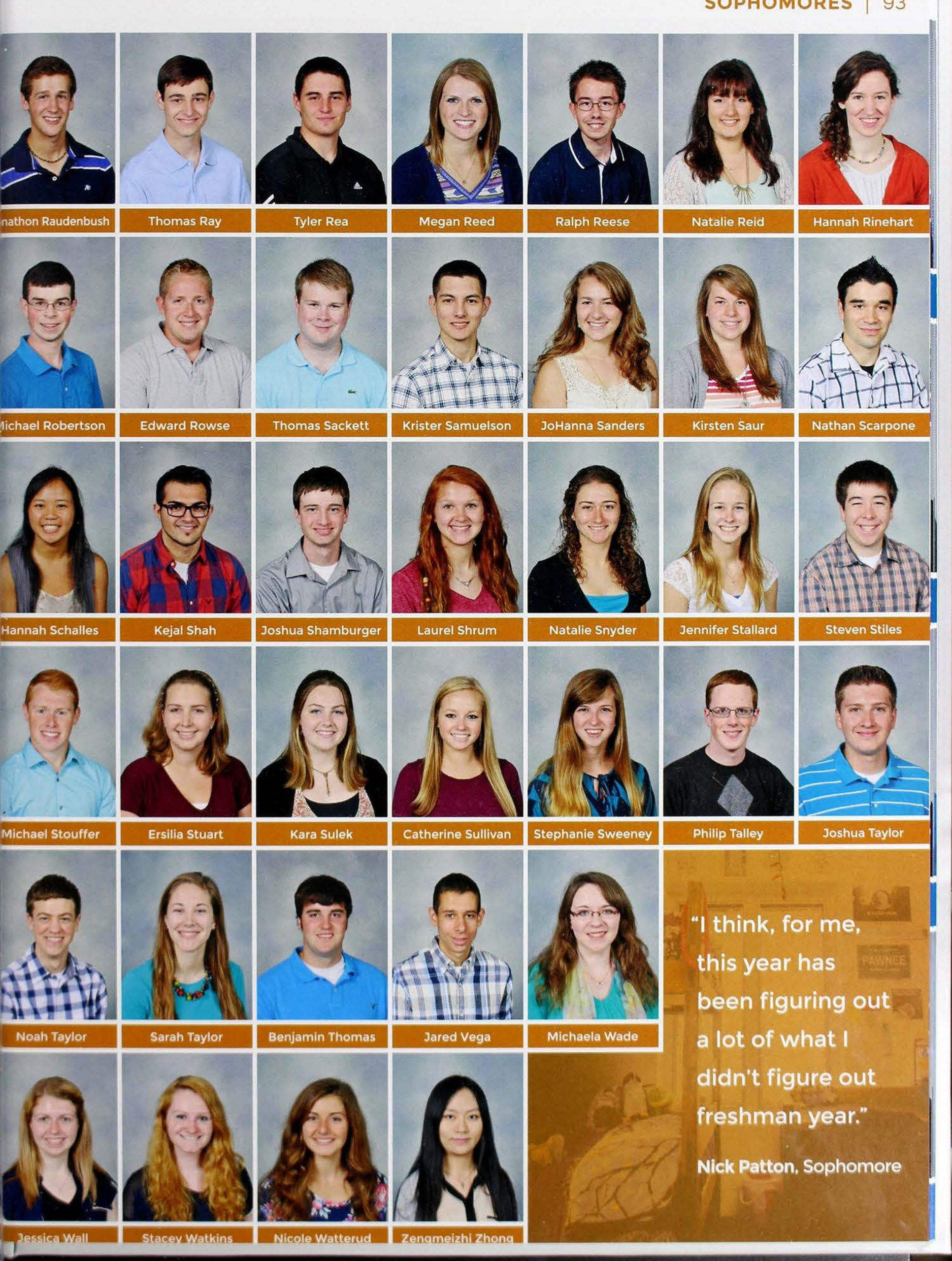




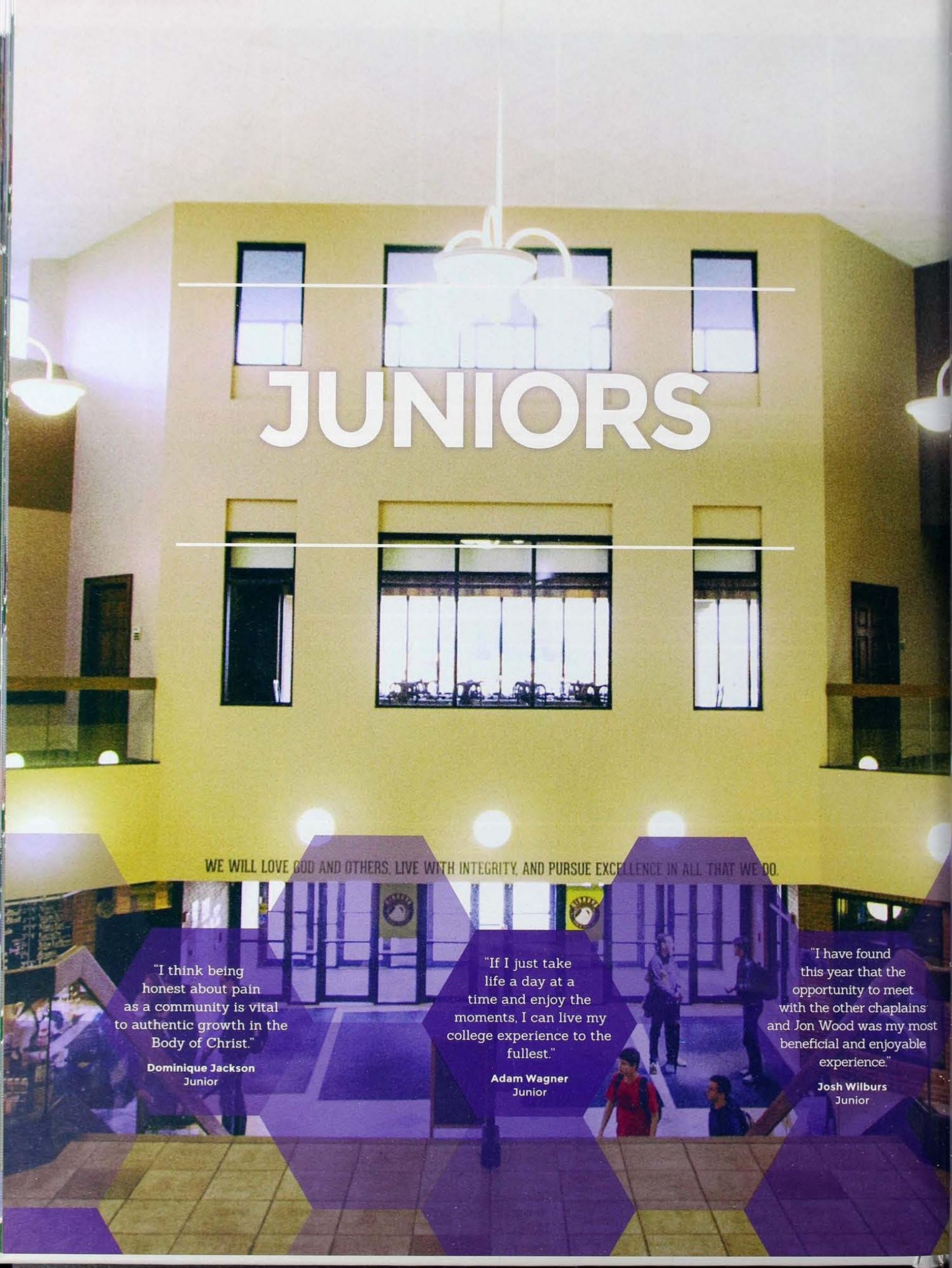




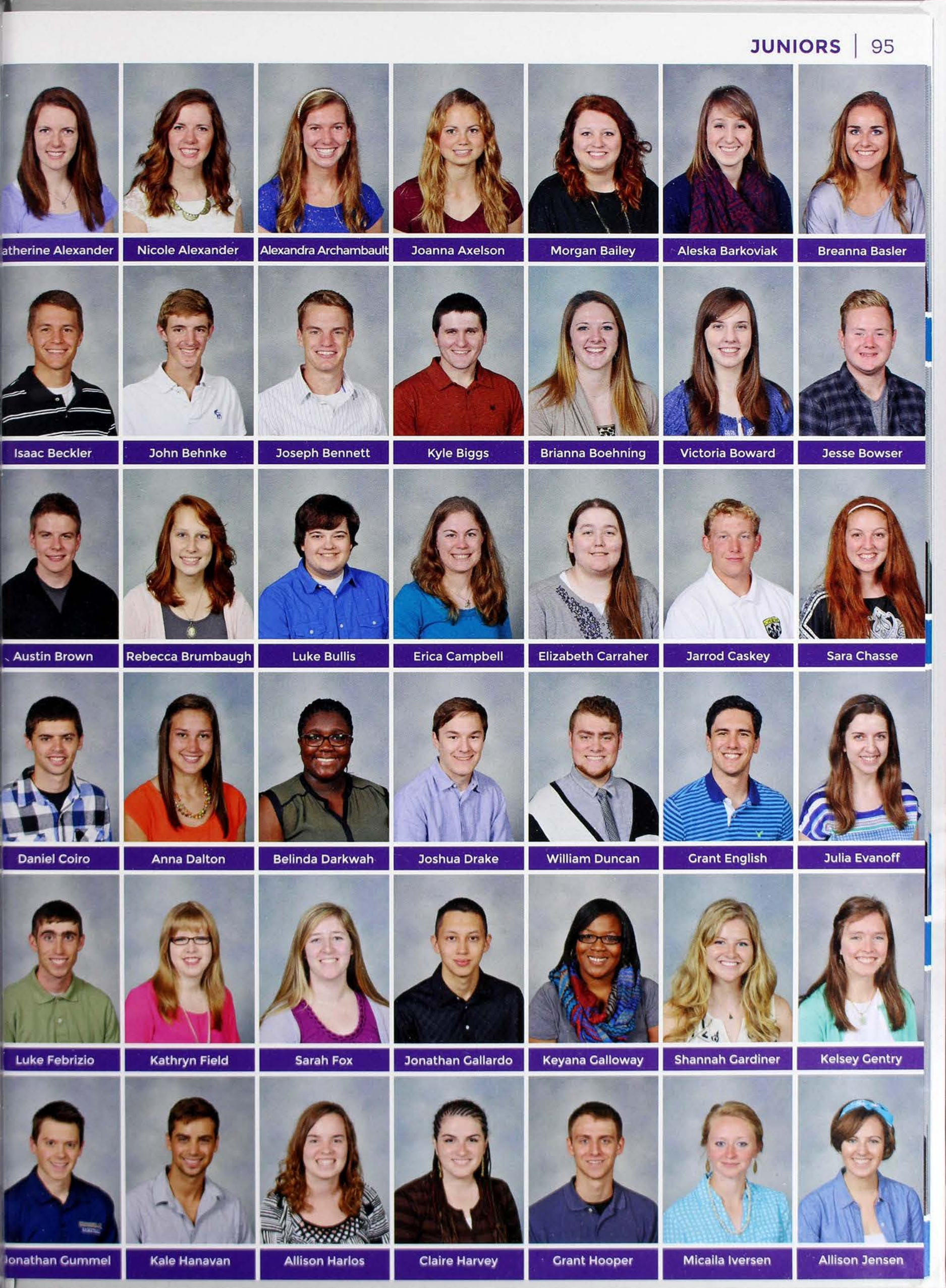




\section{6 | JUNIORS}

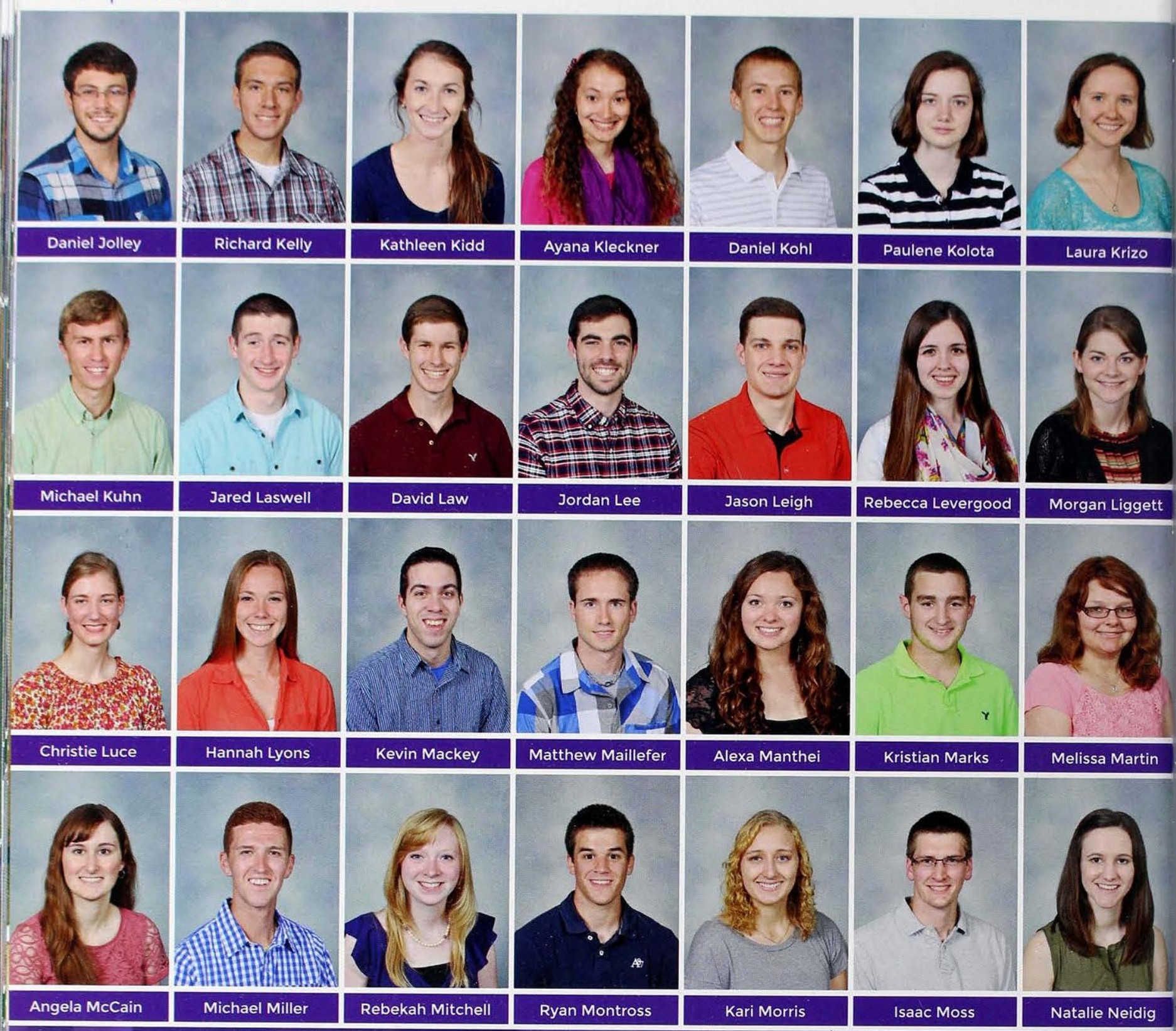

“Coming from California, and having experienced hurt and brokenness because of certain friendships, I doubted the existence of a community that encouraged and pushed one another towards Christ. However, coming to Cedarville, God has used OneVoice, Discipleship Ministries, and hearts of my peers to show me that healing from brokenness comes through vulnerability and passionately pursuing Him together." 
\begin{tabular}{l|l} 
JUNIORS & 97
\end{tabular}

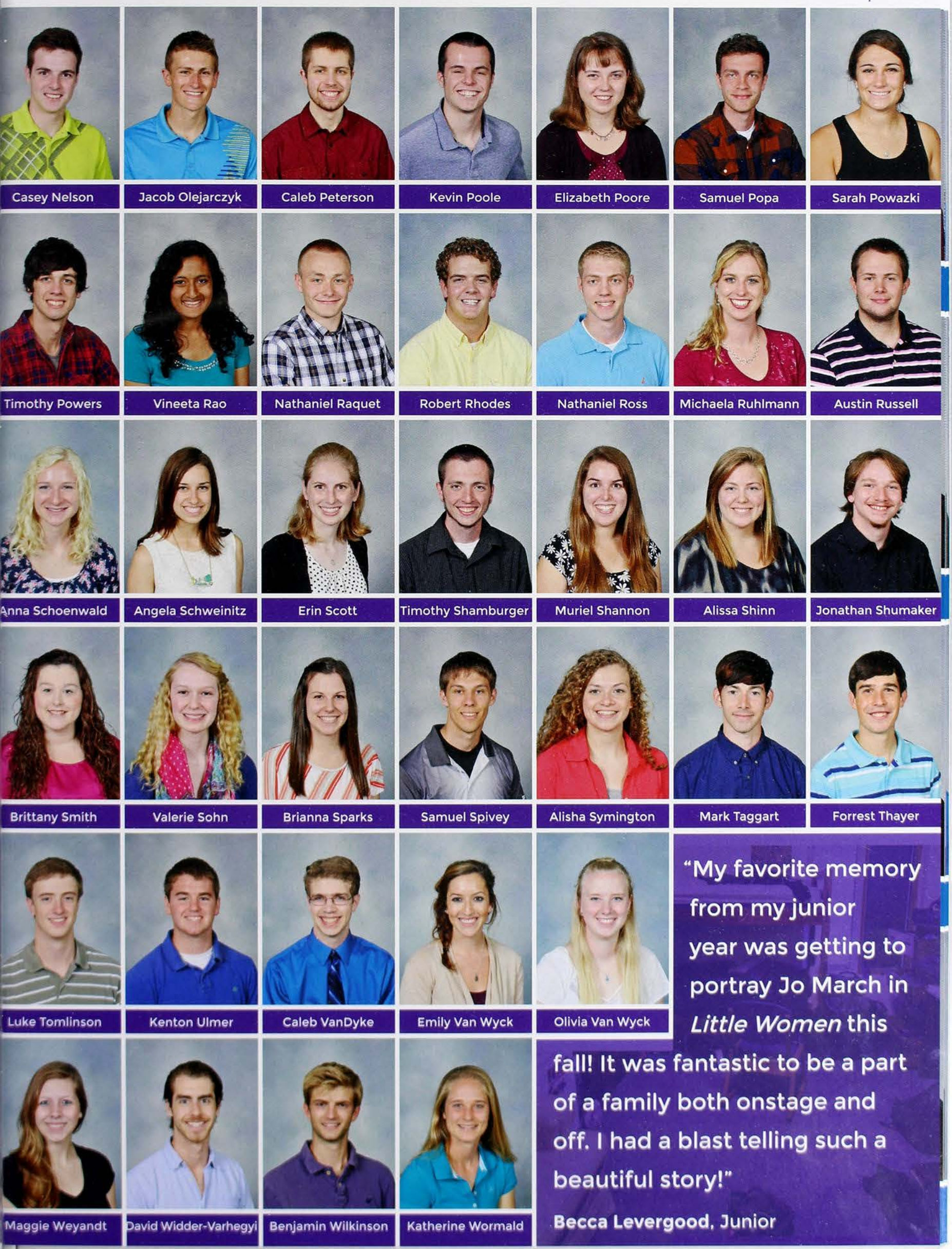





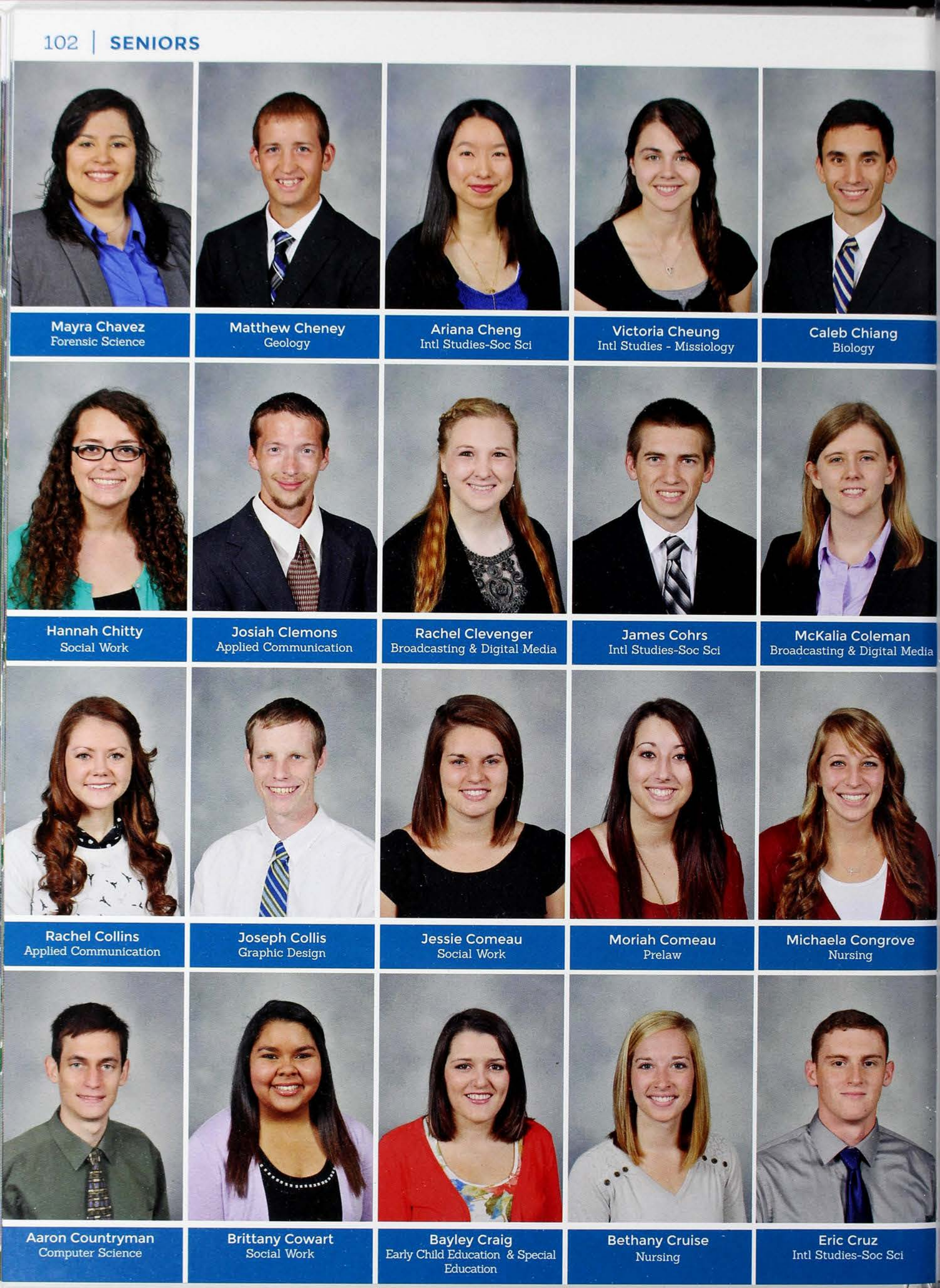





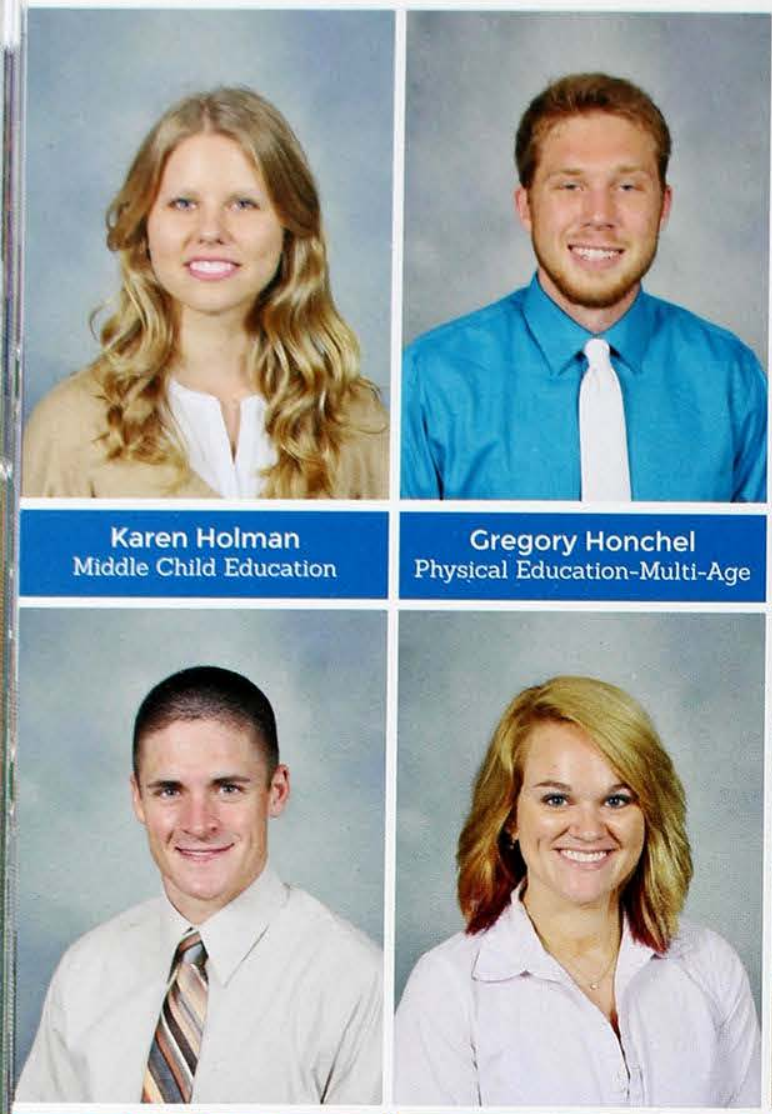

Gregory Honchel

Physical Education-Multi-Age

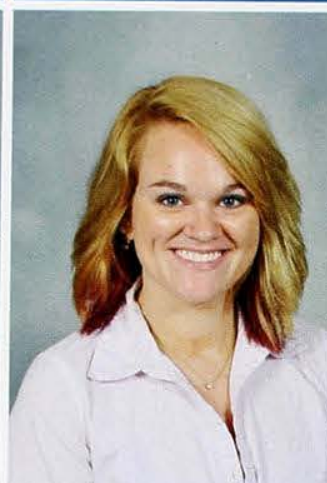

Nathaniel Hughes

Social Studies Educ-

Integrated \& Multi Age PE

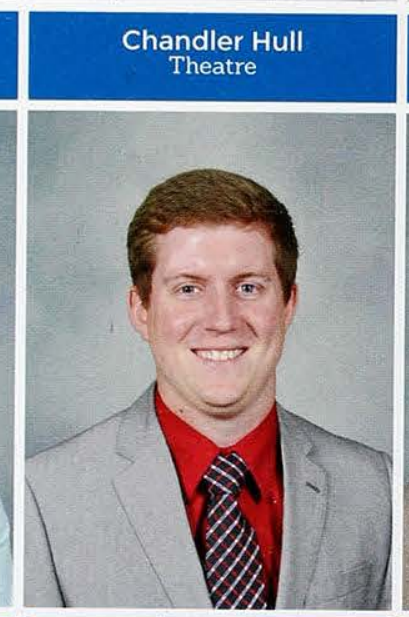

Chaney Isley Intl Studies-Soc Sci Linguistics
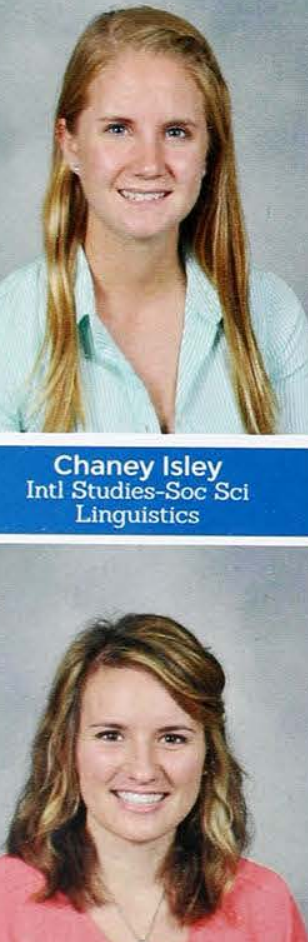

Bryce Jackson Nursing

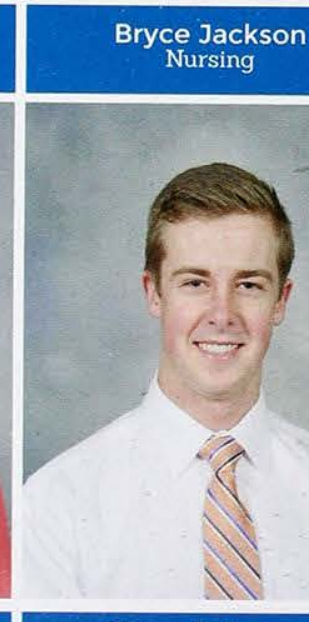

Shane Johnson Chemistry

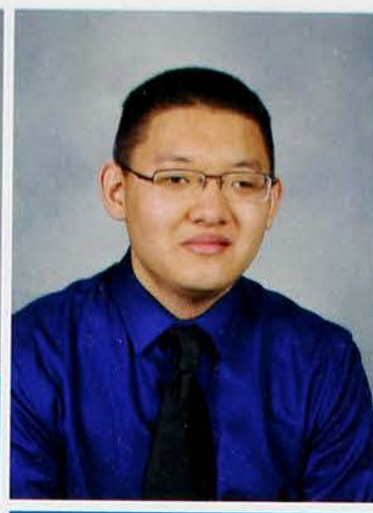

Freeman Hou

Pharmaceutical Science

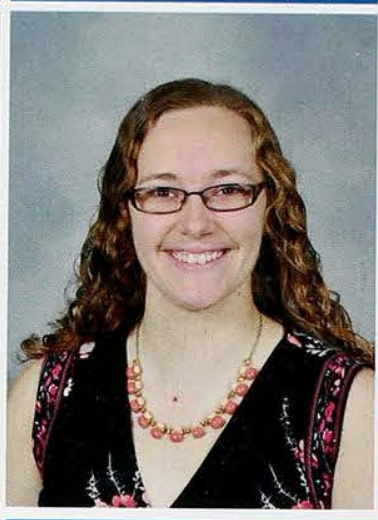

Anna Hurtubise
Molecular \& Cellular Biology
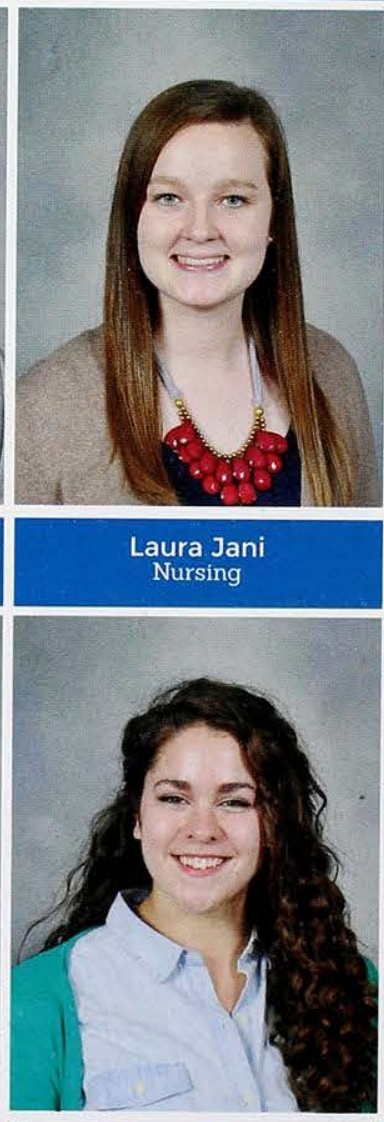

Alaina Jones

Early Child Education \& Special Education
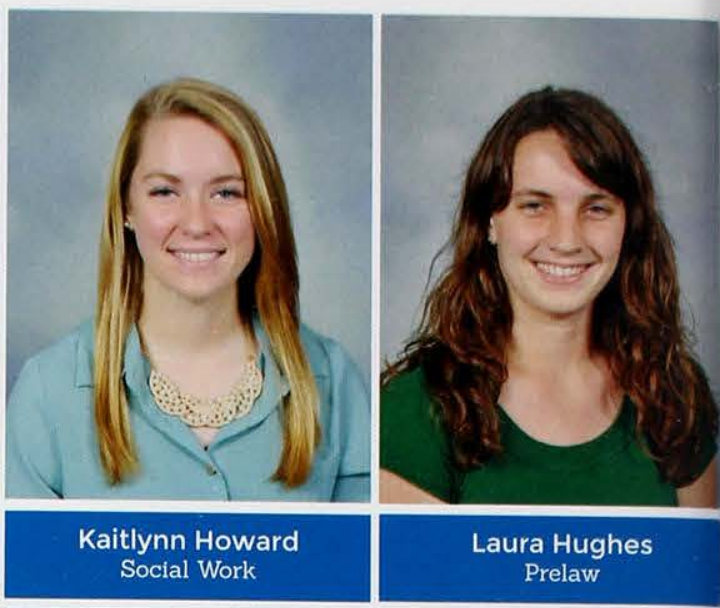

Social Work
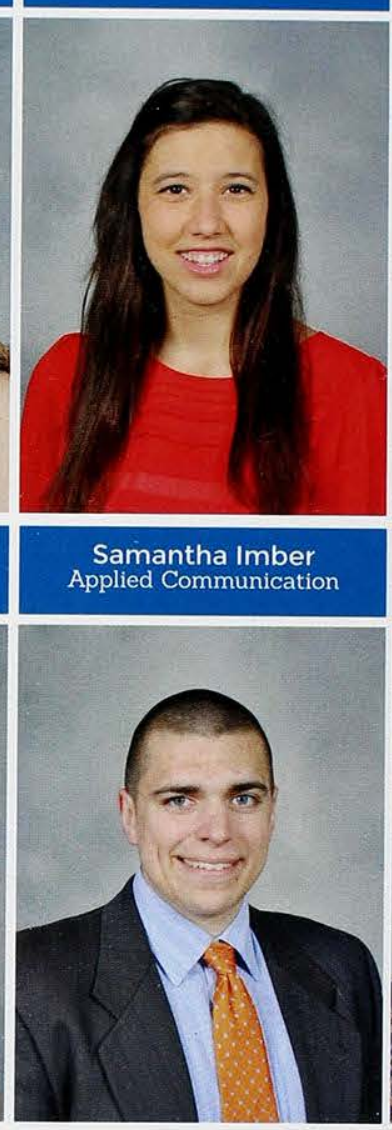

David Johnson Worship

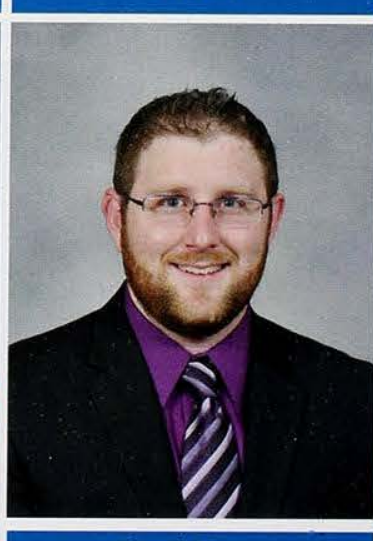

Chad Jones

Broadcasting \& Digital Media
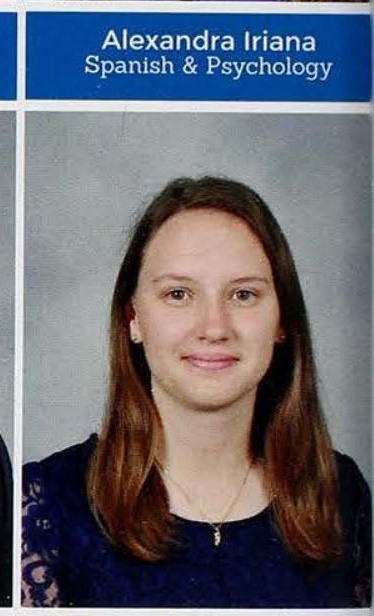

Jennifer Johnson Bible Preseminary

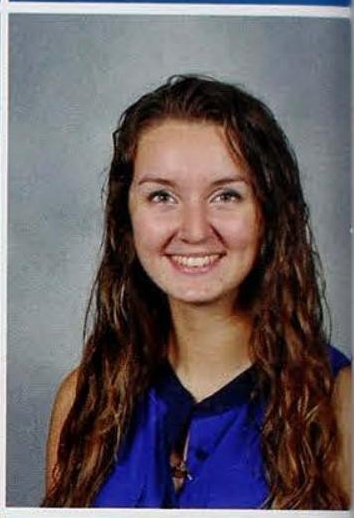

Alexandra Iriana

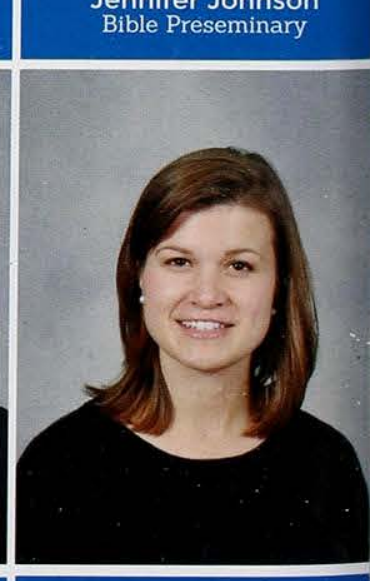

Aubrey Juris Biology 



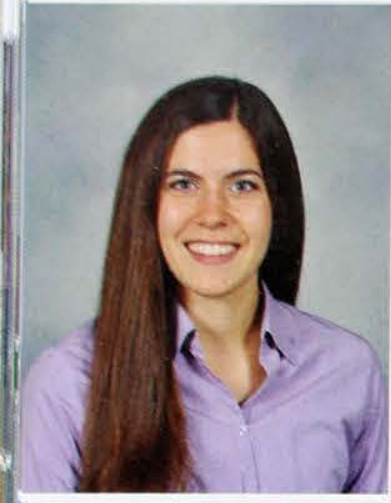

Amber Lee

Mech Engineering

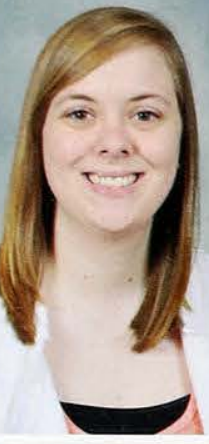

Carissa Leitch

Nursing

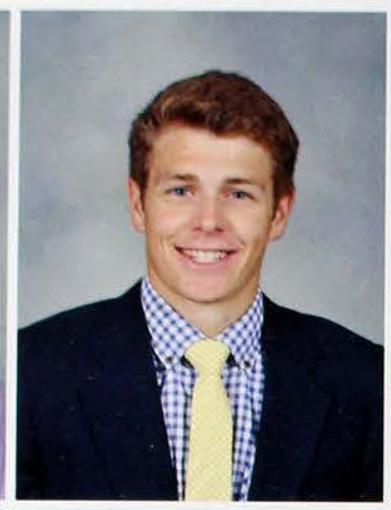

Ethan Lee

Finance

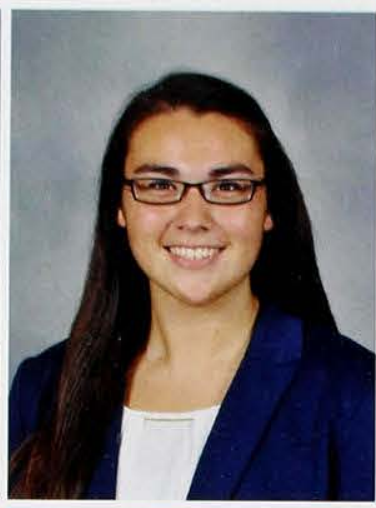

Jennifer Lee

Early Child Education

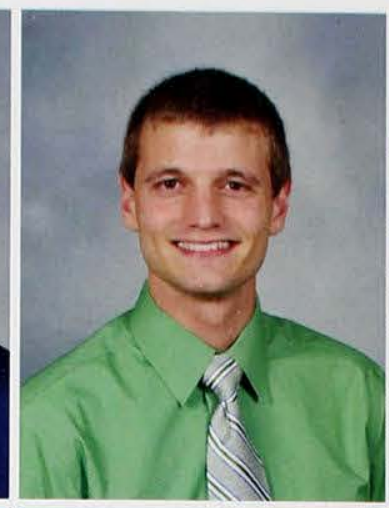

Matthew Lee

Mech Engineering

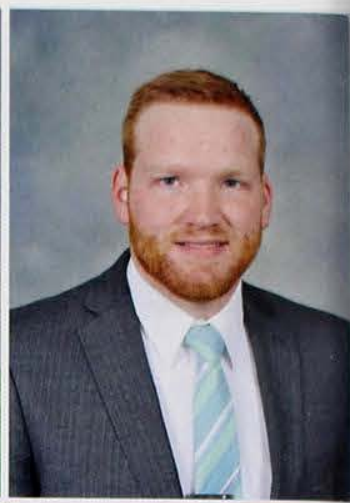

Derek Leichty

Information Technology Mgm

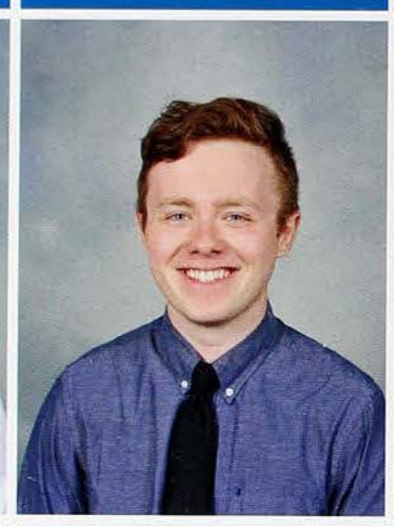

Edward Liggitt

Applied Communication

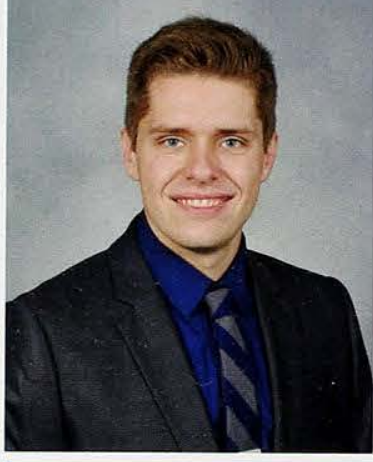

Adam Littlefield

Broadcasting \& Digital Media

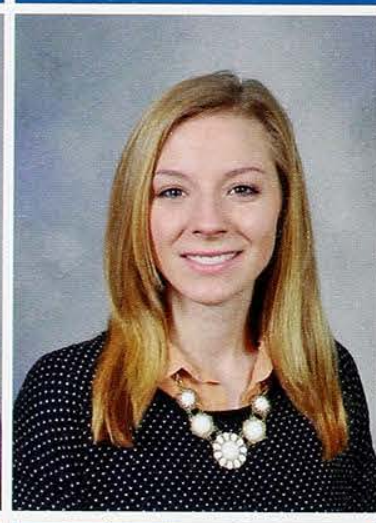

Jordan Luce

Intl Studies-Soc Sci
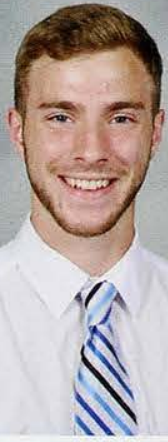

Zachary Luce

Youth Ministries

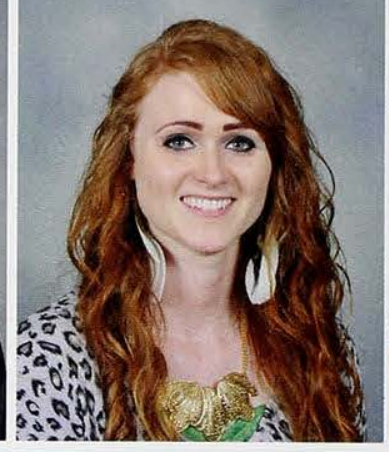

Stephanie Long Chemistry

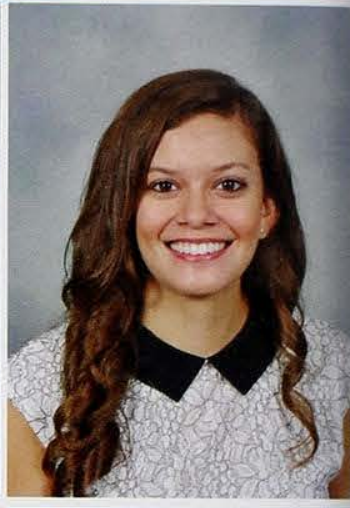

Leslie Lopez Social Work
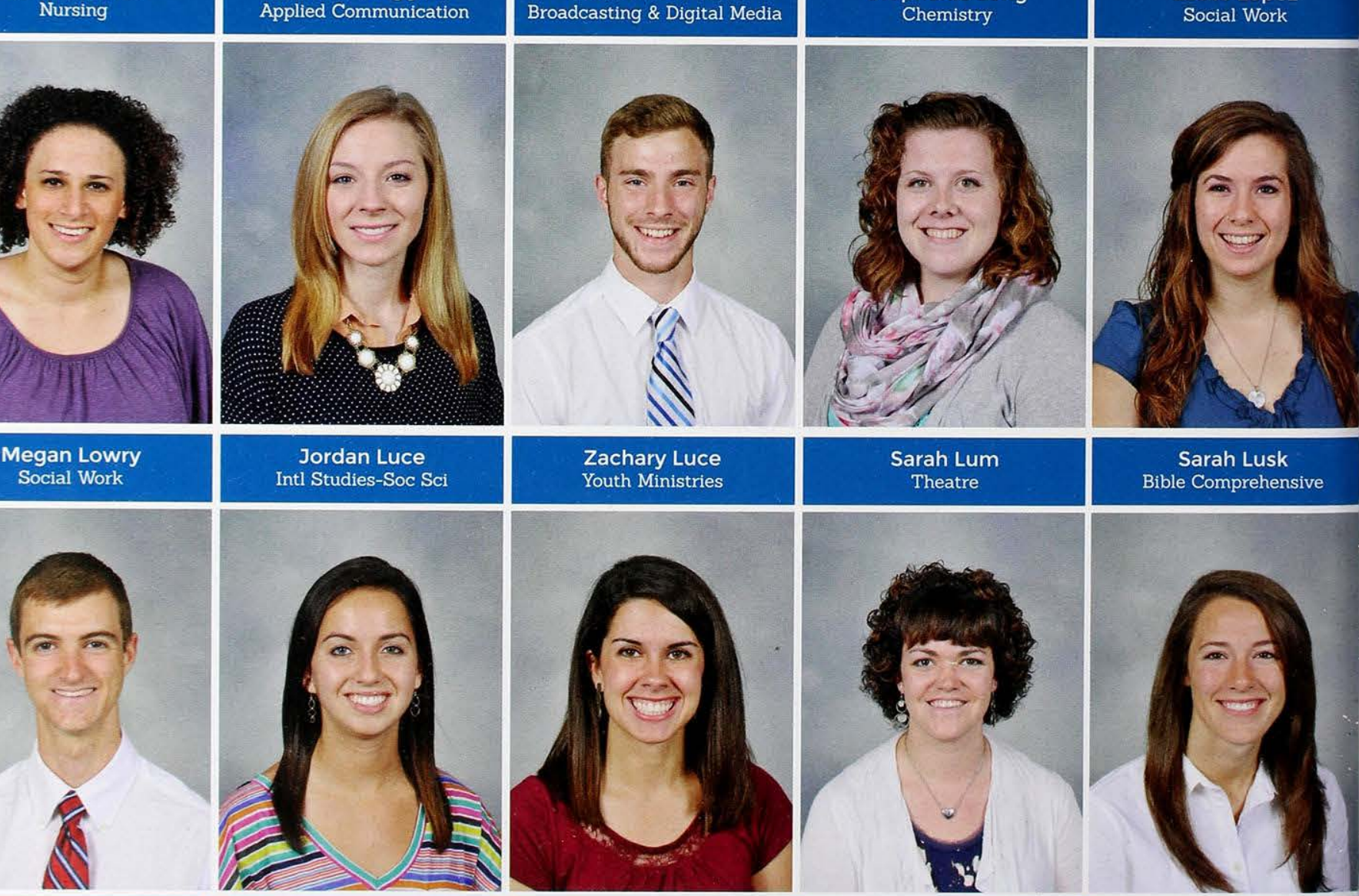

Lindsay Luzod Spanish Educ-Multi-Age

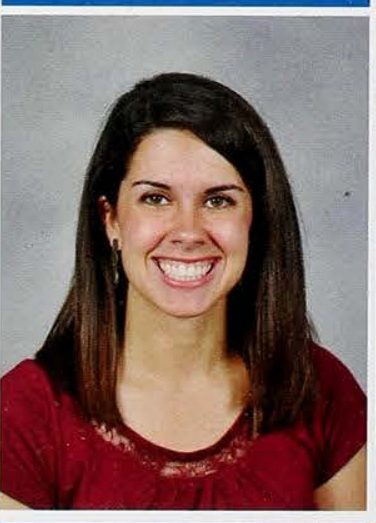

Caroline Lyons Nursing
Elizabeth MacKendrick Early Child Education

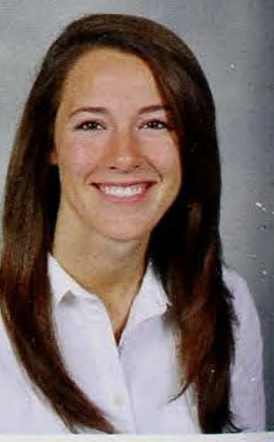

Caroline MacKenzie Nursing 

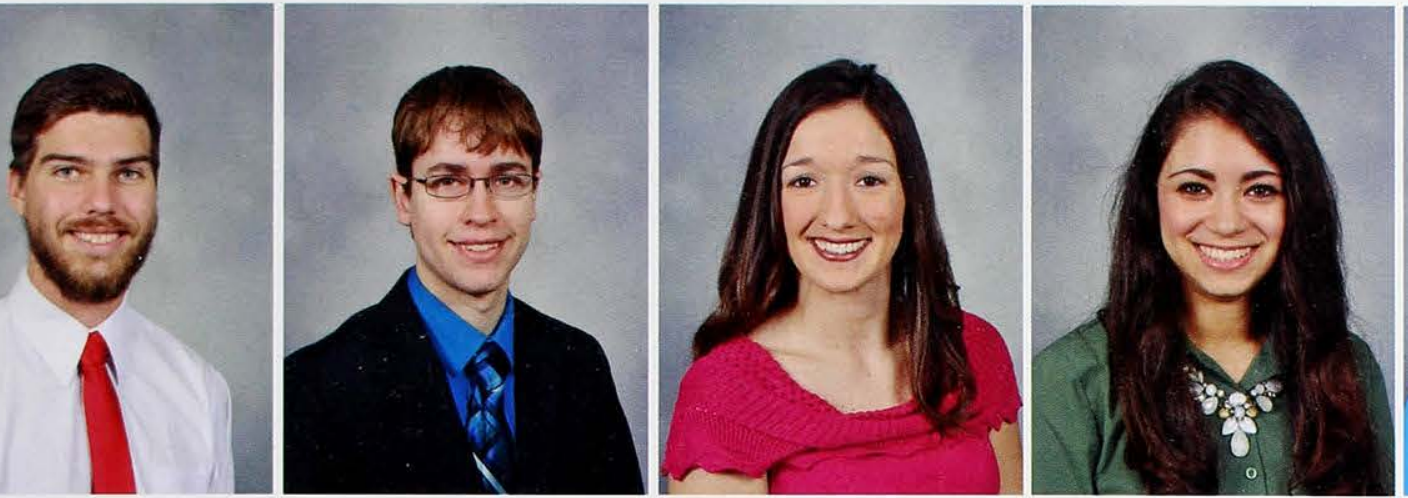

Alexander MacPhail-Fausey English

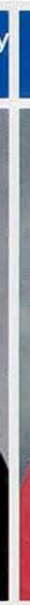

Travis Mattke

Elec Engineering
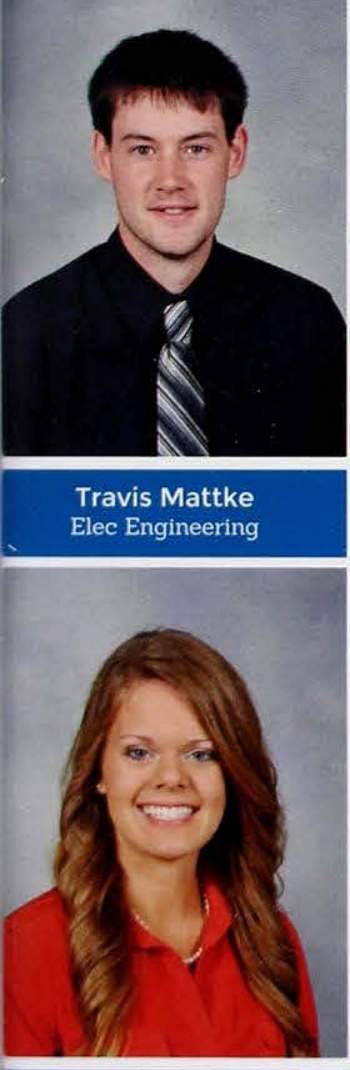

Rachel Meeker Nursing

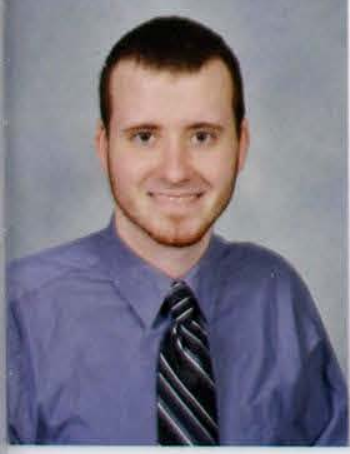

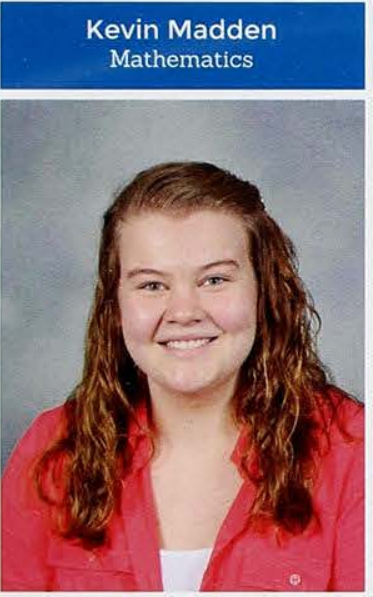

Elizabeth McLaverty Middle Child Education

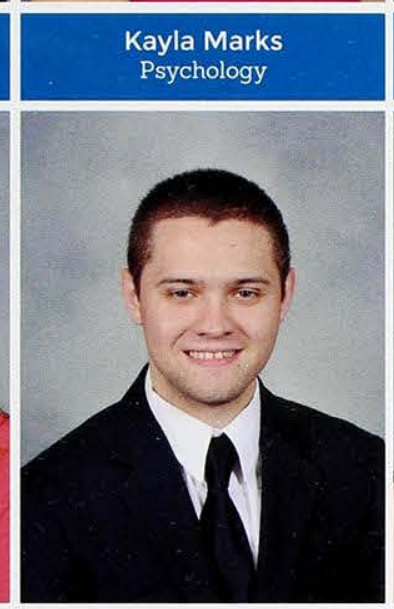

Ian McQuaid Computer Science \& Mathematics

\section{Alexandria Martella \\ Music Education-Multi-Age}

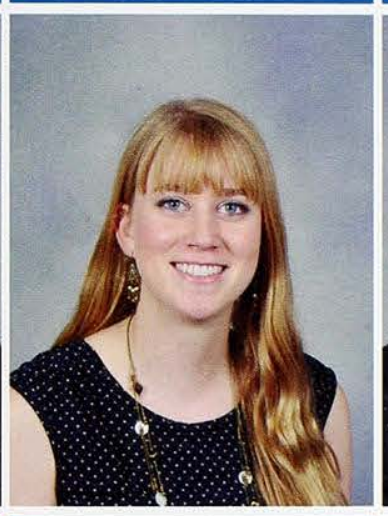

Suzanne McReynolds Nursing

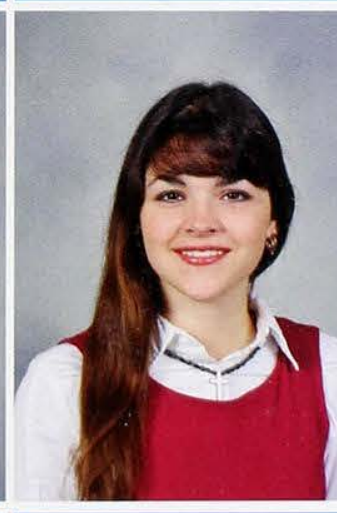

Brittney Miesse Music

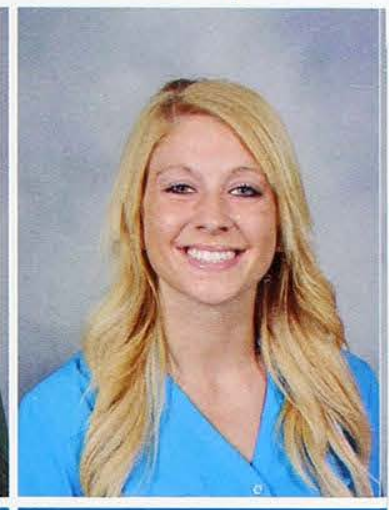

Lindsey Mattia Nursing

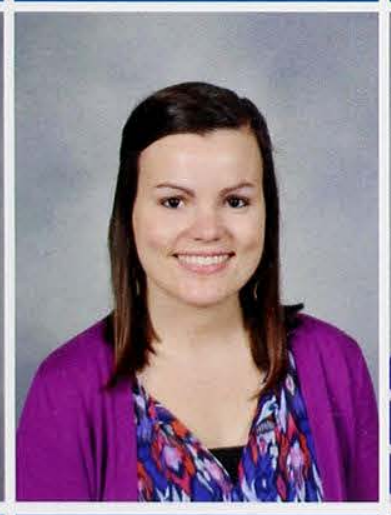

Haley Merical Athletic Training

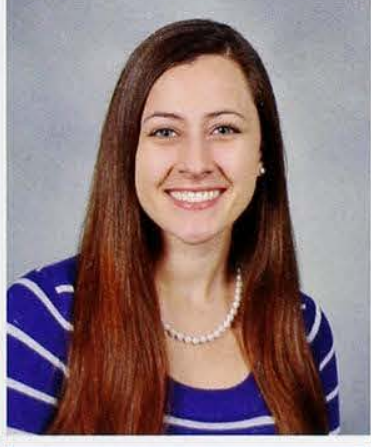

Katrina Mervine Nursing

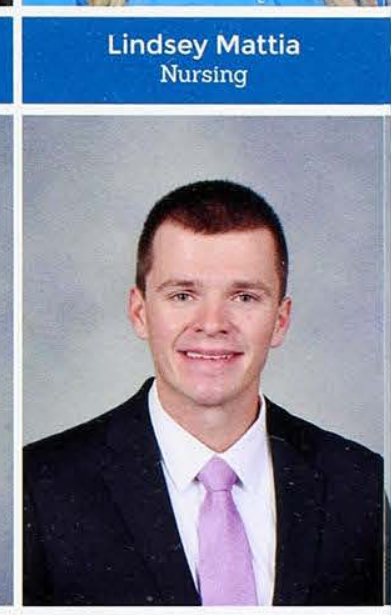

Michael Meadows Accounting

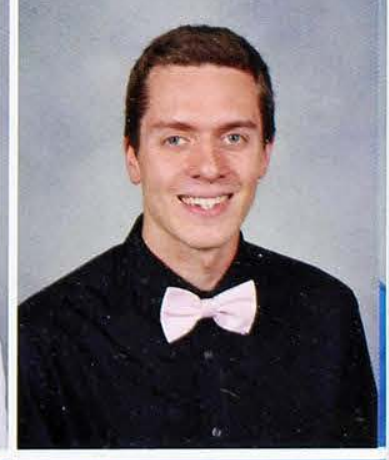

Salvatore Morrone Management

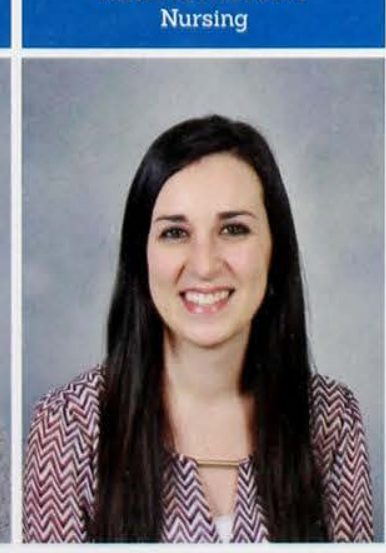

Shannon Muldowney Criminal Justice

\section{Lauren Mullahy Social Work}

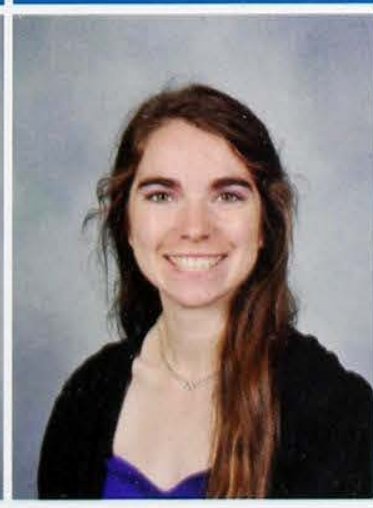

Gisela Mullican Theatre

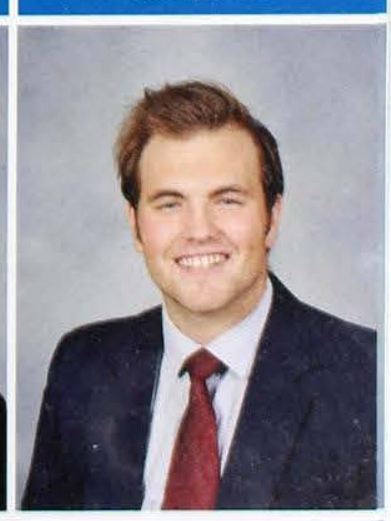

Isaac Murrell Worship 


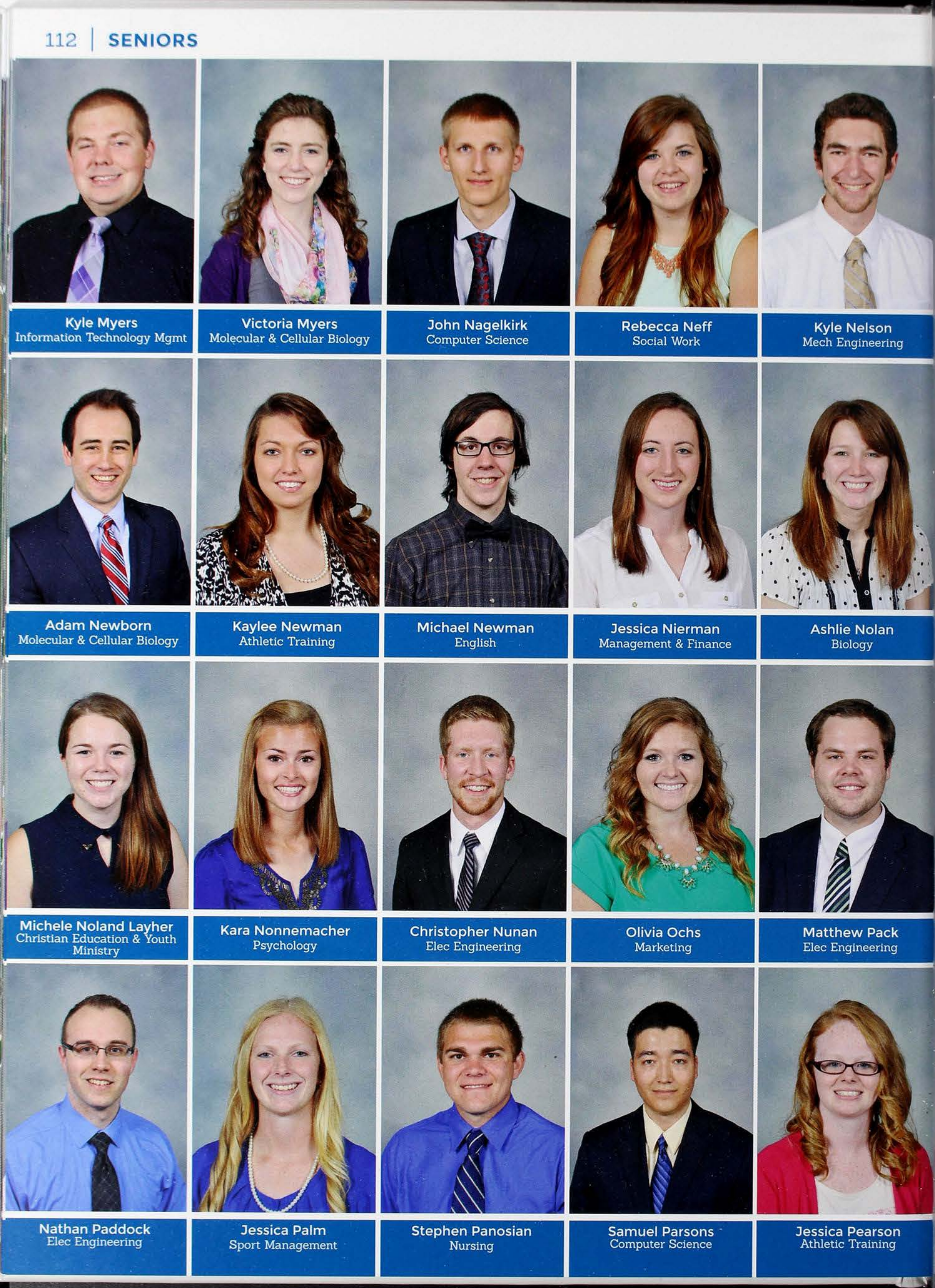





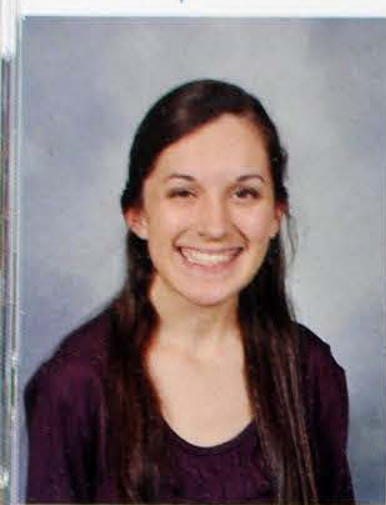

Kathryn Ritchie Nursing

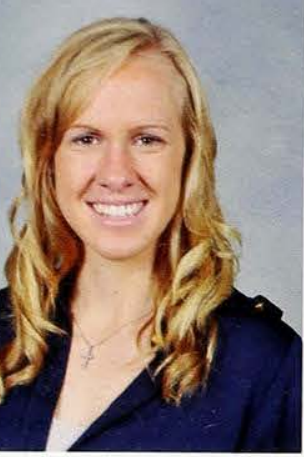

Marissa Ruedel

Christian Education

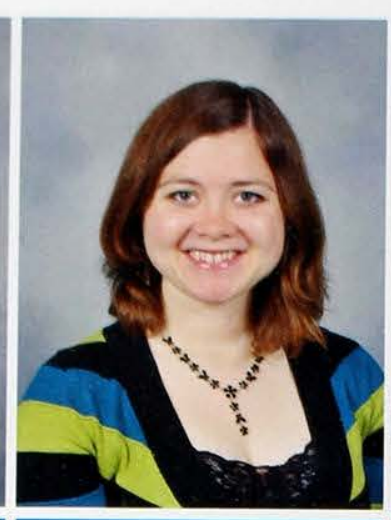

Kathy Roberts English

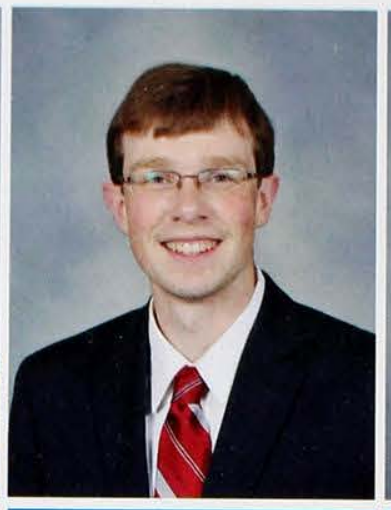

Andrew Robertson Mathematics

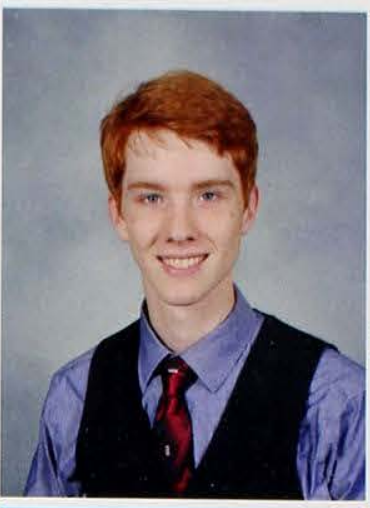

Daniel Robinson Broadcasting \& Digital Media

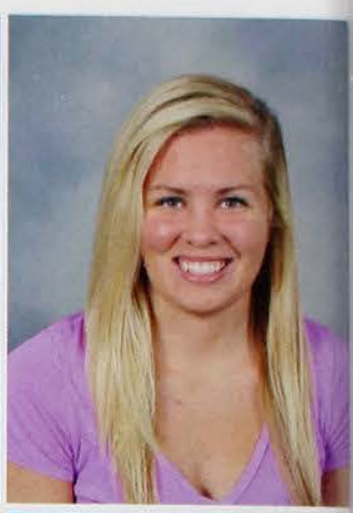

Carrie Rowlands Biology

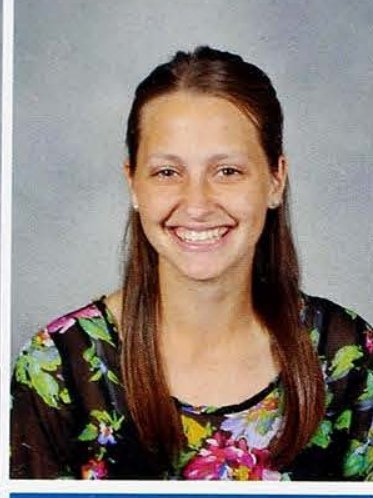

Melissa Ruhlman Nursing

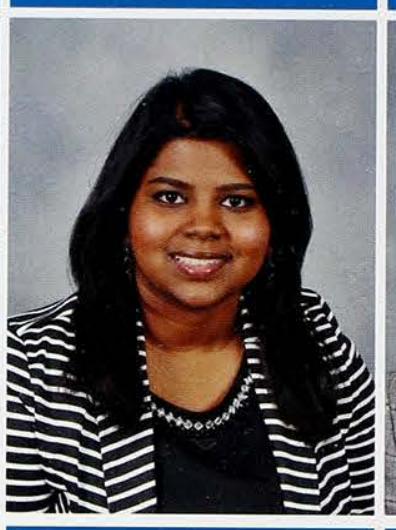

Benita Samuel Applied Communication

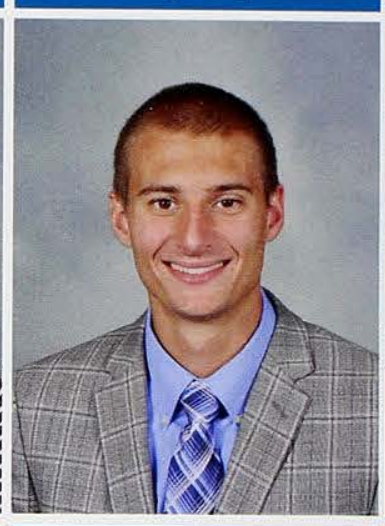

Justin Santoro

Marketing

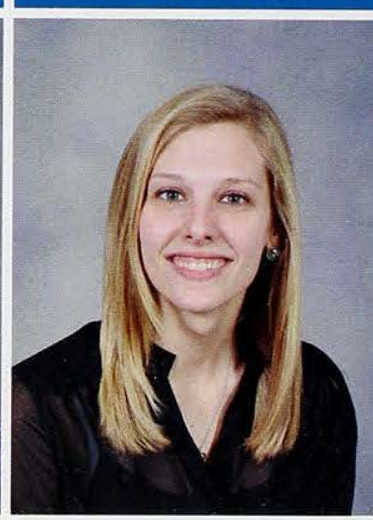

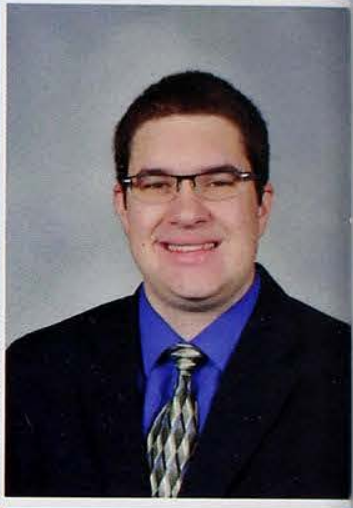

Benjamin Saxe Intl Studies-Soc Sci

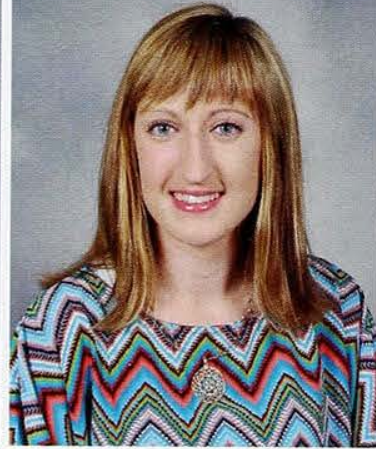

Kelly Schaffter Social Work
Samuel Scherneck Environmental Science
Emily Scheurer Nursing

Emily Scheurer
Nursing

David Saur Music

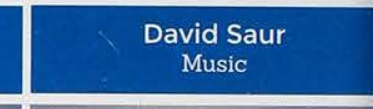

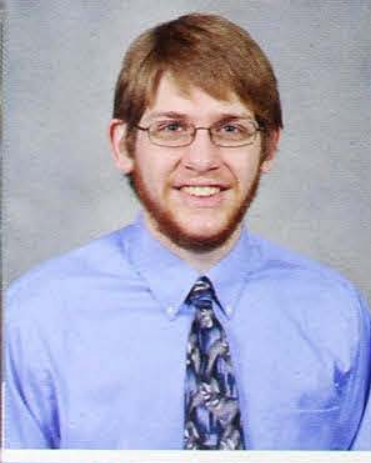

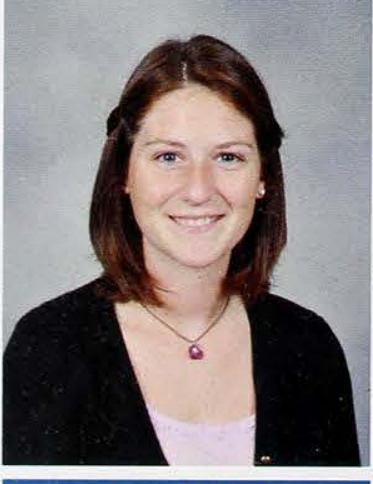

Amanda Seals Early Child Education

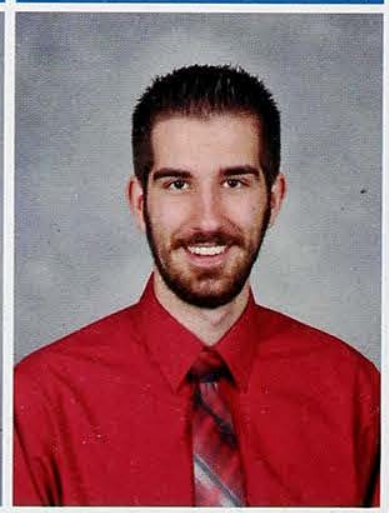

Jacob Secor Computer Science

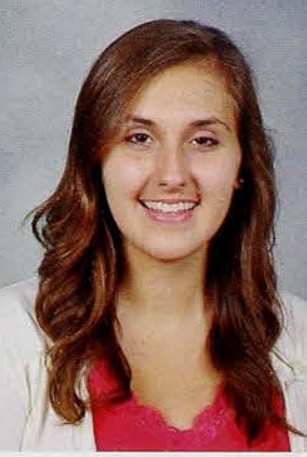

Cassandra Sensky Chemistry

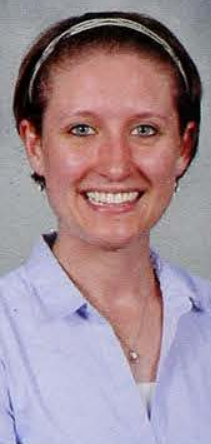

Annelise Schick Prelaw

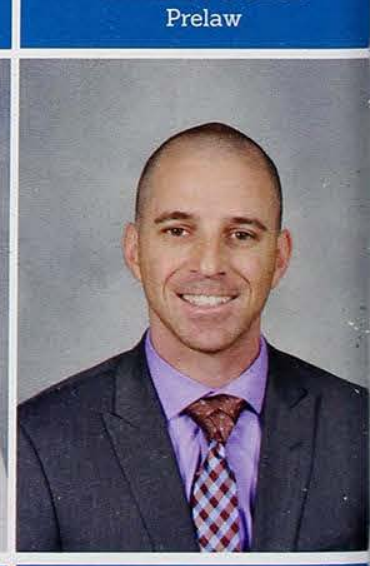

Troy Sergeant Nursing 



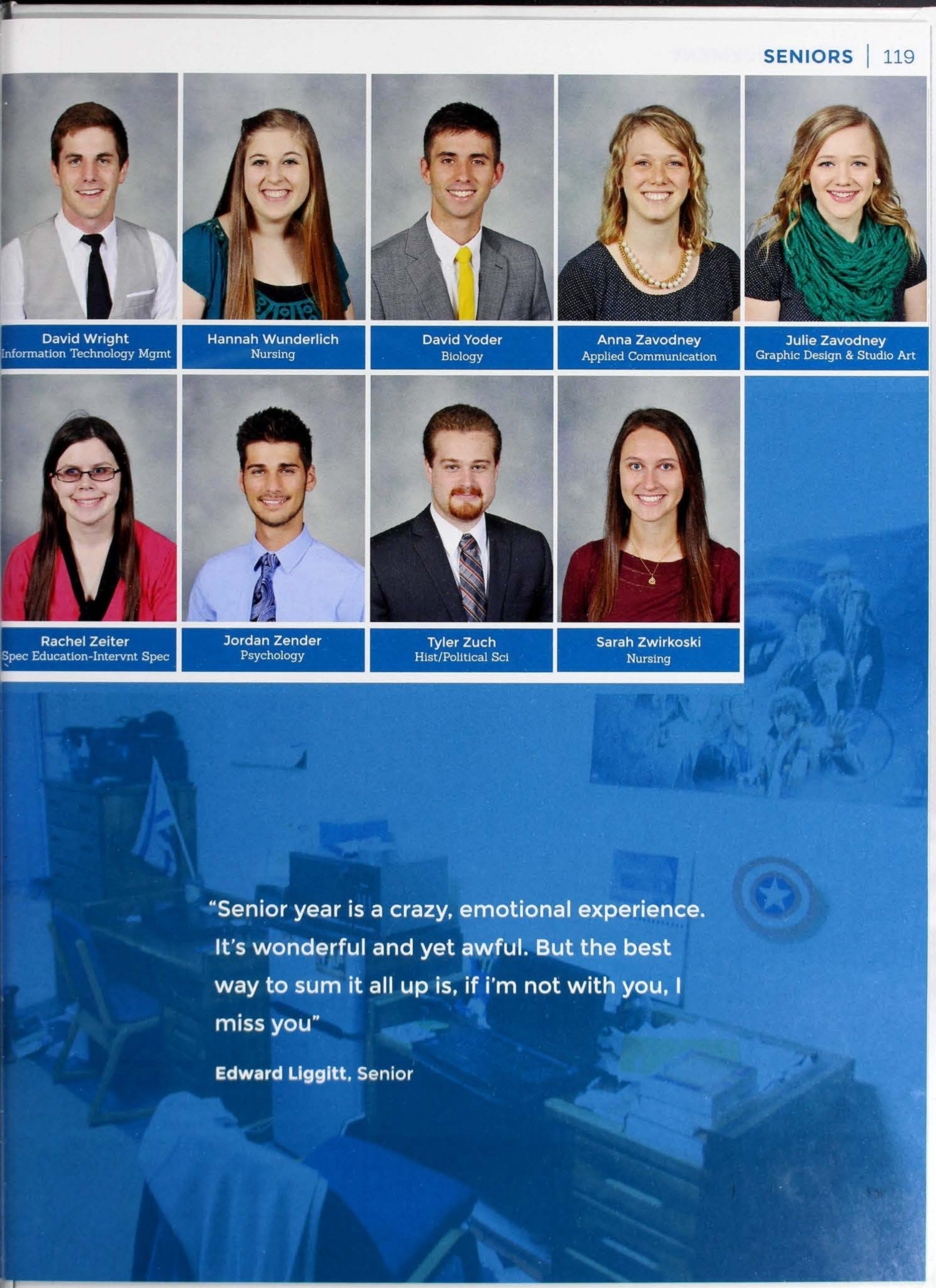



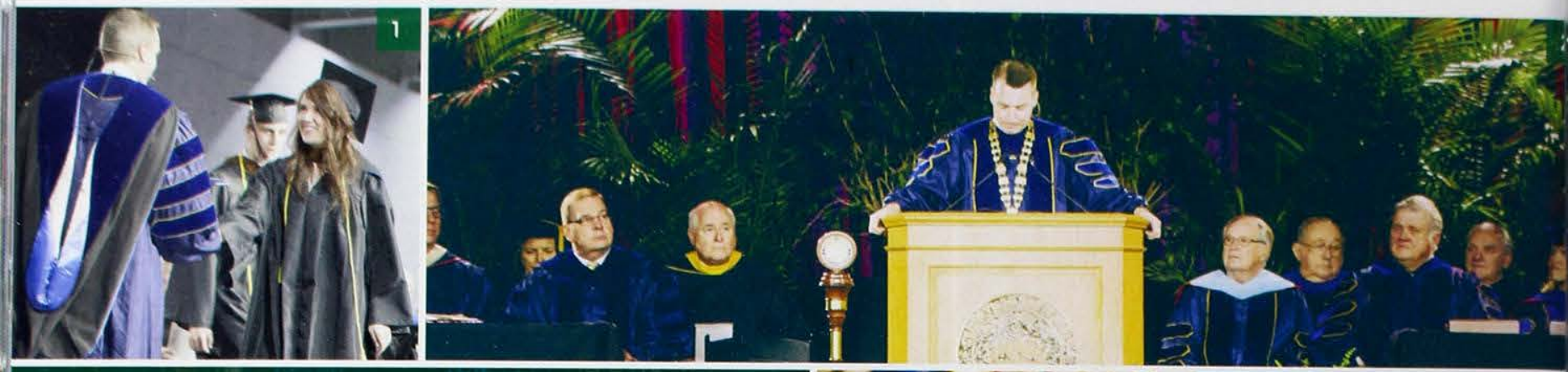

"Graduation is such a

bittersweet moment. It

made me reminisce about

all the good things and

the bad - seeing how God

worked through it all."

Cassie Peterson, Senior
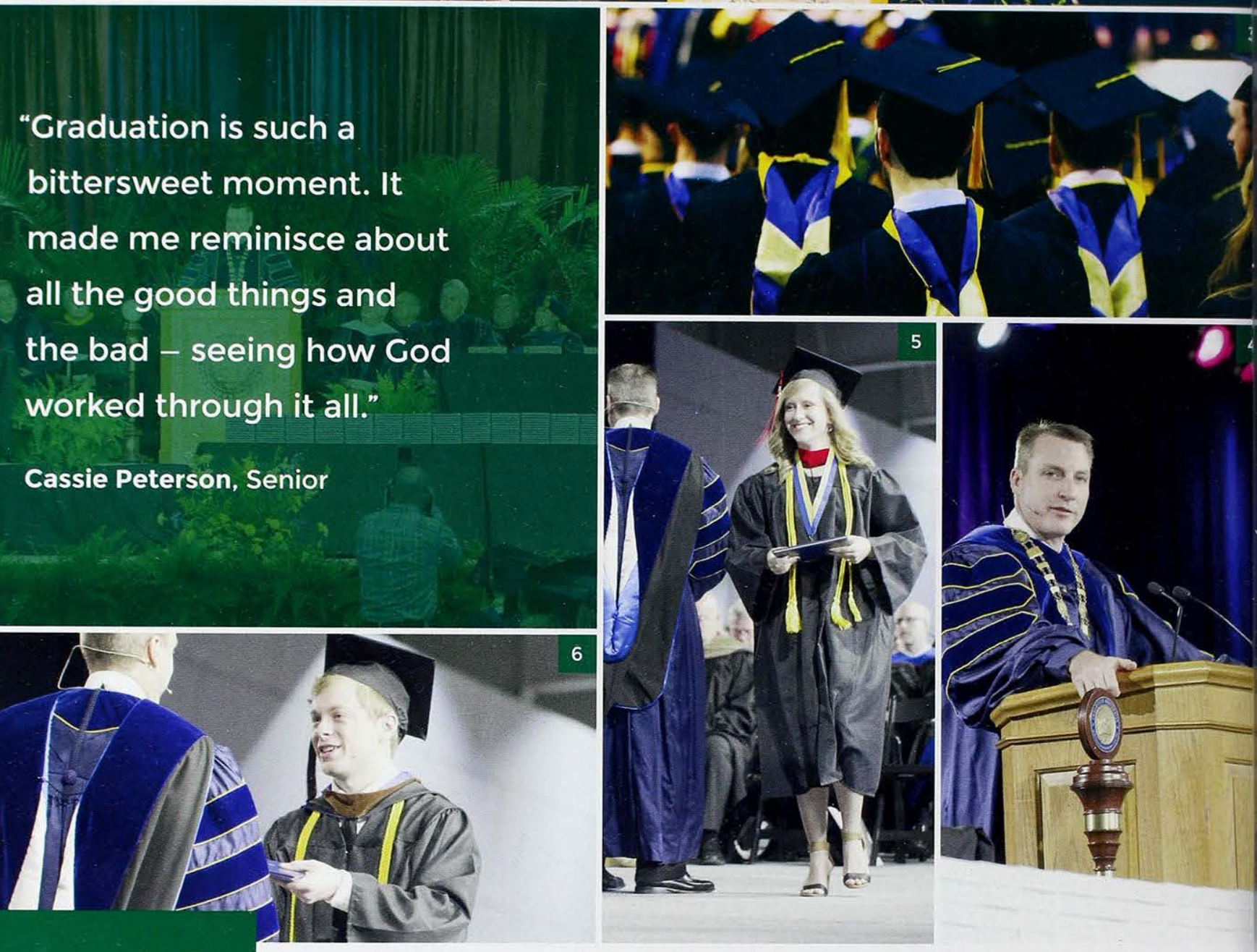

1. Elisabeth Elliott receives her diploma and $a$ handshake from Dr. White.

2. Dr. White addresses the graduates as trustees and faculty look on.

3. The Class of $\mathbf{2 0 1 5}$ awaits the chance to walk across the stage.

4. The 119th Commencement marks Dr. White's second year speaking as president.

5. Carissa Drum is all smiles after receiving her diploma.

6. Taylor Schlabaugh accepts his diploma.

\section{THE 119TH ANNUAL COMMENCEMENT}

On May 2, 2015, 745 graduates walked across the stage to receive their hard-earned degrees. Countless hours of studying, test-taking, and paper-writing finally paid off, and Cedarville University's largest-ever graduating class took their places as alumni. The class saw many changes while at Cedarville, including the renovation of Chuck's, the opening of the HSC, becoming NCAA DII, various new establishments in town, and a transition in leadership. Despite it all. Commencement Day was a joyous occasion. As friends parted ways to enter into the next phase of life - grad school, work, travel, or even marriage - the words of Dr. Murdoch rang true: "God is faithful. You can trust Him." 

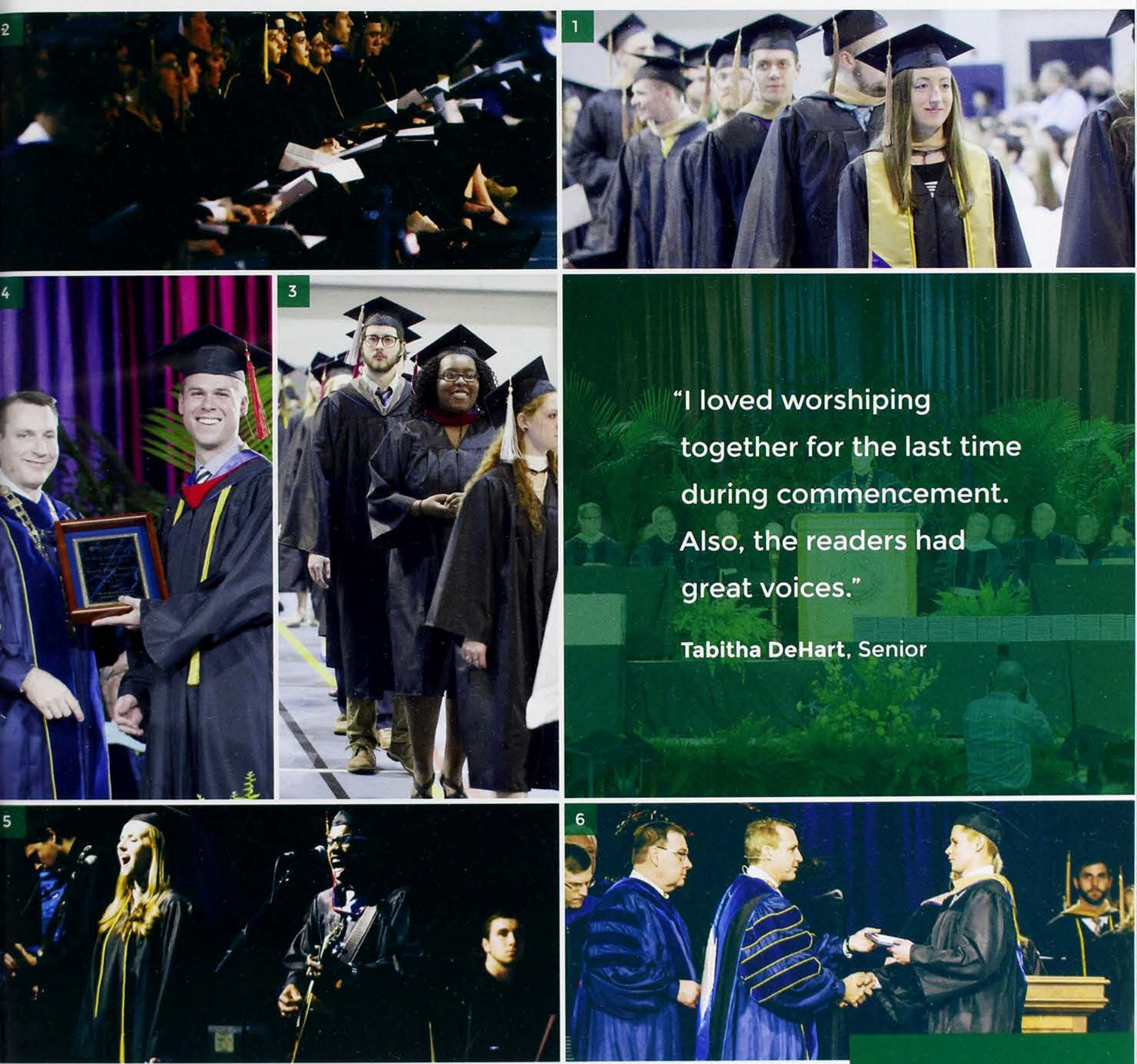

\section{"I loved worshiping}

\section{together for the last time} during commencement. Also, the readers had great voices."

\section{Tabitha DeHart, Senior}

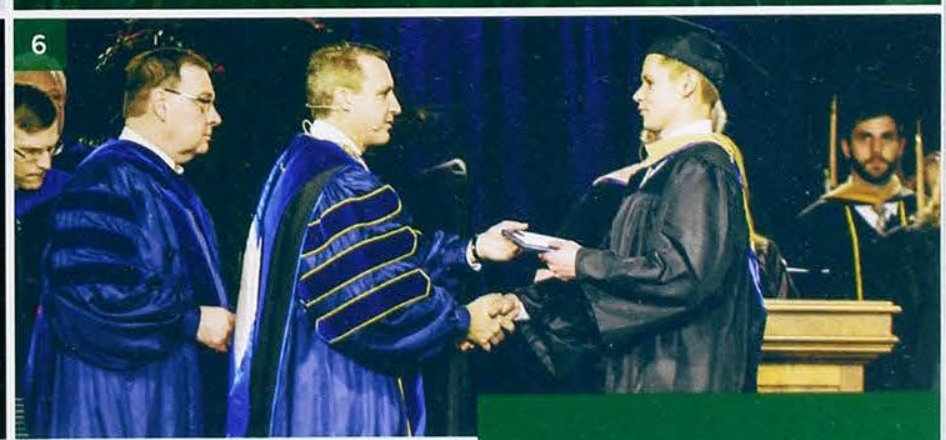

"My time at Cedarville has been some of the most memorable and difficult years I have lived thus far. I am so thankful to have gone through both seasons of life at a place where I was surrounded by the love of Christ, which there was hardly ever a day I didn't come in contact with."

Alissa Shinn, Junior
1. Jessica Nierman holds her head high and proud as she walks into Commencement.

2. The graduates look forward to a bright future.

3. Commencement Day brings smiles to all.

4. Andrew Gutberlet poses with an award from Dr. White.

5. Abby Israel and Michael Pettus sing the class song, Oceans.

6. Josh Thifault and Dr. White share a handshake. 

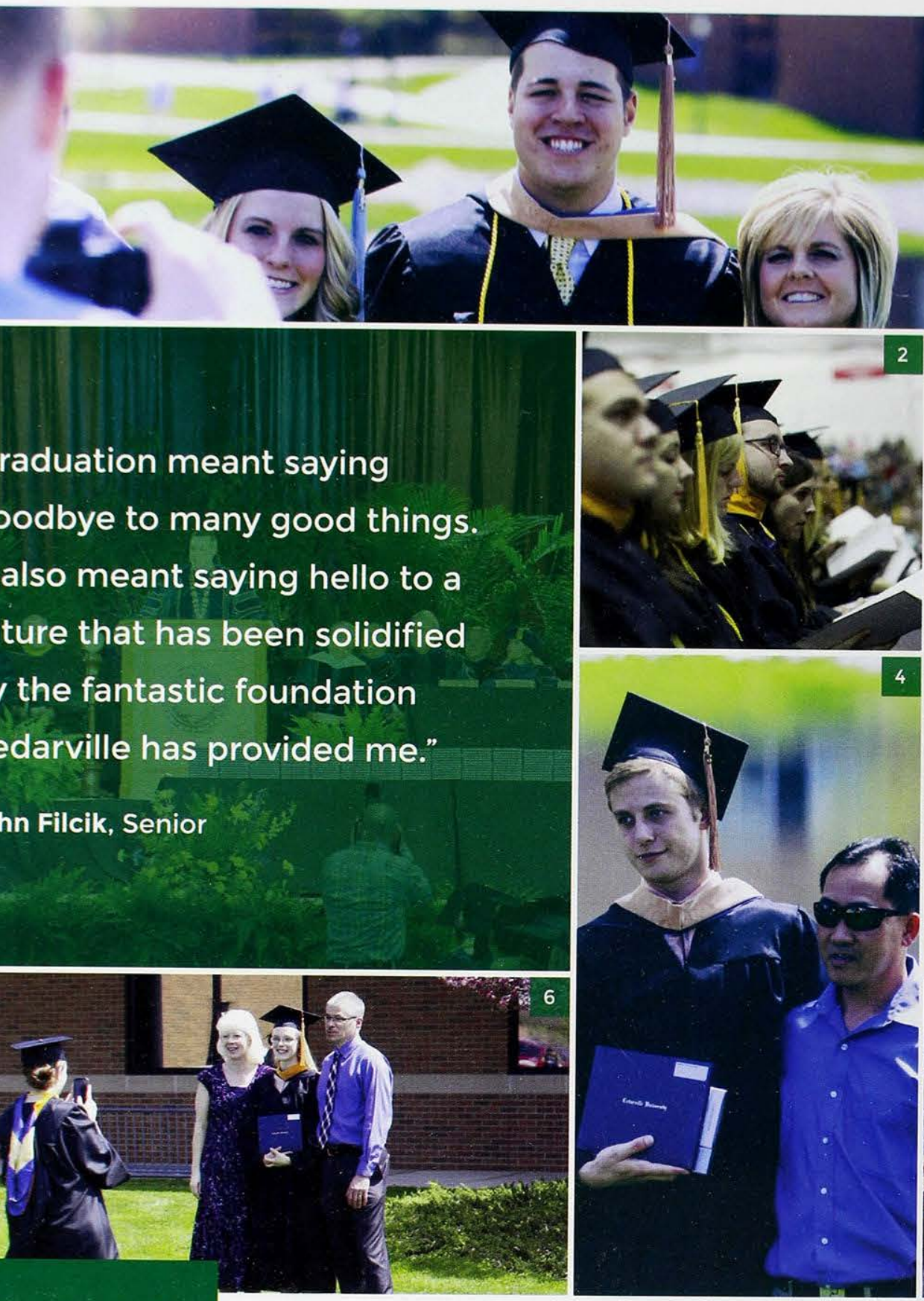

"Graduation meant saying

goodbye to many good things.

It also meant saying hello to a

future that has been solidified

by the fantastic foundation

Cedarville has provided me."

John Filcik, Senior
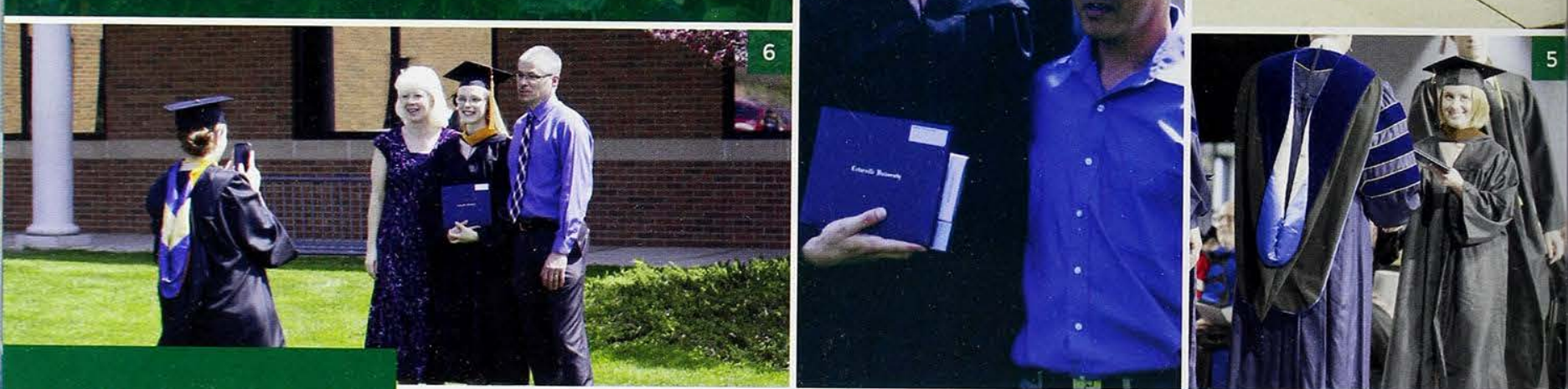

1. Peter Martin snaps a photo with his family.

2. Jon Reitinger awaits the moment he will receive his diploma.

3. Josh Petrel poses for a photo.

4. Sam Isner shows off his diploma.

5. Kayleigh Clark accepts her diploma.

6. Hannah Wunderlich snaps a picture of her roommate Rachel Tyler and her parents.
"I am excited about graduating and moving on to the rest of my life. I feel like Cedarville has prepared me to move into my career and I am excited to begin using my nursing practice to show and spread Christ's light. My favorite part of commencement was walking across the stage. In those few moments. I felt proud of myself for making it, humbled that Christ brought me through all my tests and papers, and amazed at all the love and support that I felt from those watching in the audience. In that moment I truly felt equipped to move on, knowing that I was not leaving anything behind, but instead taking it with me."

Hannah Wunderlich, Senior 


\section{LETTER FROM THE EDITOR}

Busy. The most common response to the "how are you?" question, and a word that I hear in increasing frequency on campus as the end of the academic year approaches. Busyness seems to be an epidemic that every student eventually catches during their time at Cedarville. Personally, Im glad that life is never boring, and that there is no lack of projects to work on or events to attend. Unfortunately, to those who struggle establishing a realistic or healthy work/life balance, busyness can be a dangerous ailment. There are moments (like when I have a paper to write, a quiz to take, and homework all due the next day) when I find myself impatiently looking forward to the day when I am "finally done with college!" It's in these moments where I need to remind myself of reality.

As nearly all those who have passed through the cold waters of academia and into post-collegiate life remind me: life only ever speeds up after graduation. Everyone is busy. Having a million things on your plate just seems a part of being a grown-up. Last semester I made it a goal to avoid using the word "busy" at all costs. When someone asked me how I was doing, I tried to think of an interesting story or part of my life to relate. Rather than simply describing my hectic schedule, I attempted to share moments. The past four years have taught me that the only controllable aspect of busyness is our response to it. To do this correctly, I believe one must alter the way that he or she views the blur that is our lives.

Sound familiar? That's the theme of our book. Life is so much sweeter when we focus on the moments and small blessings that make life.a joy. I hope this book brings back fun memories, rather than that overwhelming feeling that the stress and busyness of college brings. I wonder if years from now well find ourselves flipping through this book, and fondly recall moments from our time at Cedarville that helped define not only our college experience, but the beginnings of adulthood. When life was just a little simpler, and bit less_busy.

\section{So_how are you?}

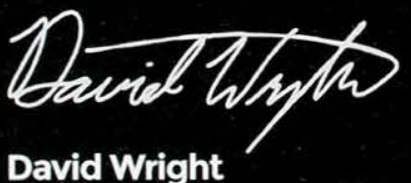

\section{Editor-in-Chief}

\section{A few shoutouts:}

Shoutout to my parents and grandparents for making the last four years a possibility - thank you for all your undeserved love and support. Thank you to the friends I have been blessed to get to know over the past four years; your wisdom and encouragement has been so appreciated. Another big shoutout to Caytlin, my beautiful / brilliant fiancée. Thanks for encouraging me to pursue crazy involvements like Yearbook. Thank you to our advisor, Cyndi Messer, for putting up with me for another year. And finally, thank you to my Yearbook staff for your diligence and excellence this year. Each of you have made the team a joy to lead. 


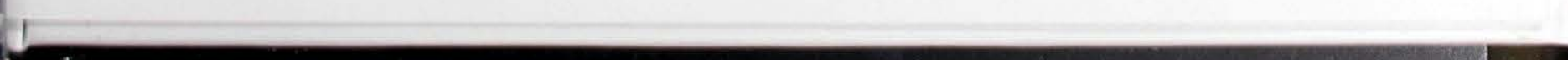





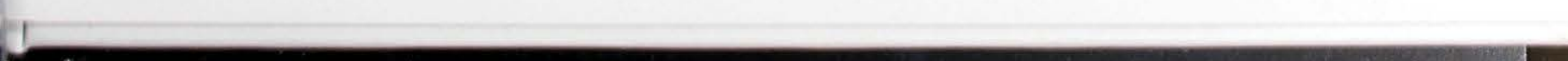





